\title{
Automated Vehicles and Third-Party Liability: A European Perspective
}

\author{
Dr Michael Chatzipanagiotis \\ Dr George Leloudas ${ }^{1}$
}

\begin{abstract}
This article examines third-party liability issues of automated vehicles (AV) as currently regulated in Europe at the level of the European Union (EU) and at national level. The analysis of European law is preceded by a brief presentation of international law on traffic rules, whose binding effect has influenced the content of European provisions. Regarding national legislations, we examine the special rules of the German Road Traffic Act, which focuses on the liability of keeper and the driver, as well as the English Automated and Electric Vehicles Act 2018, which focuses on insurance and represents a different approach. We combine the analysis of the special rules with an overview of the applicable provisions on product liability and driver third-party liability in these countries. In addition, we briefly present the legal rules applicable in the US and compare them with the European ones. We conclude our article with some thoughts on eventual amendment of the existing rules de lege ferenda, aimed to inform the discussions globally on how to regulate civil liability arising from the use of AV.
\end{abstract}

Keywords: automated vehicles, driverless cars, product liability, road negligence, third-party liability, drivers, insurance law, EU law, German law, English law, European law, comparison EU-US law, AI

\section{Contents}

Introduction: Technical parameters and automation levels of AV

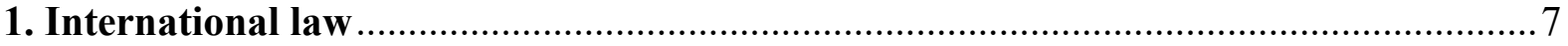

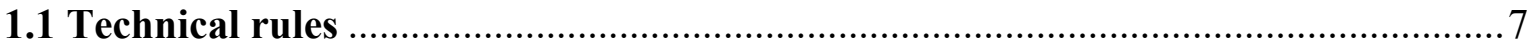

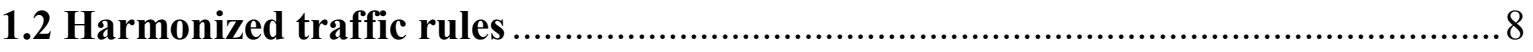

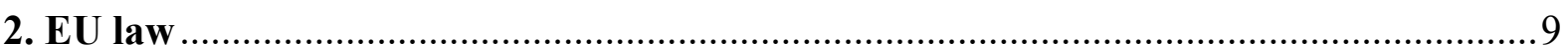

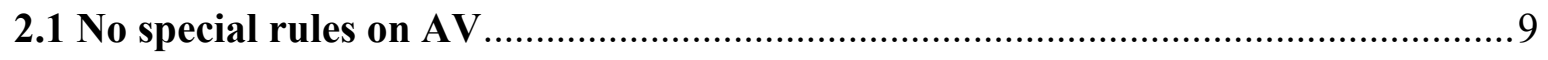

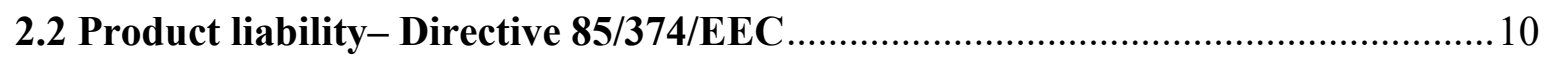

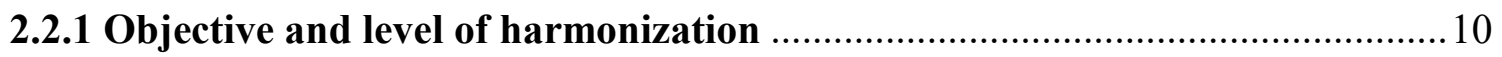

\footnotetext{
${ }^{1}$ Dr Michael Chatzipanagiotis is a Lecturer in Private Law at the Department of Law of University of Cyprus. Dr George Leloudas is an Associate Professor at the School of Law of Swansea University and member of the Institute of International Shipping and Trade Law (IISTL). Before joining academia, both authors were legal practitioners in their respective jurisdictions (UK, Greece and Cyprus) on issues of transport, insurance and consumer protection. The views expressed herein are strictly personal and do not necessarily reflect the views of any organizations the authors may be affiliated with.
} 


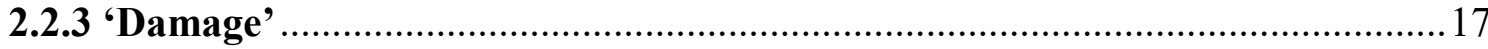

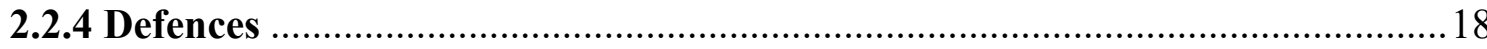

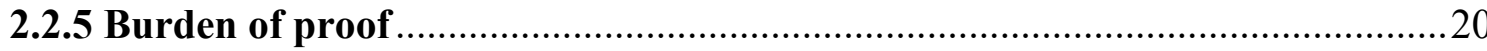

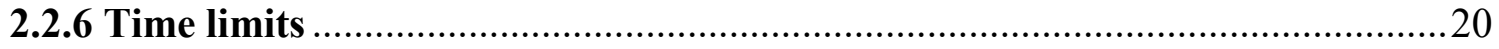

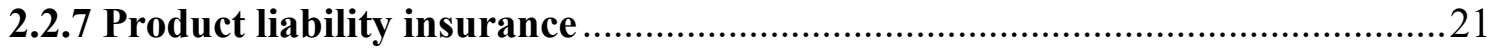

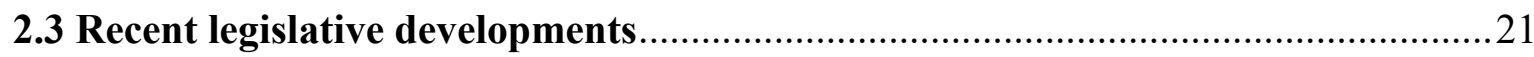

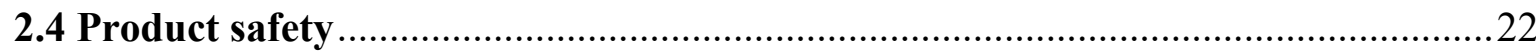

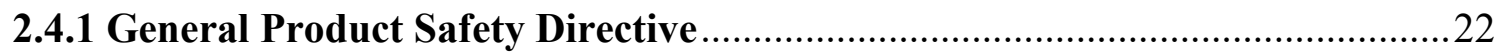

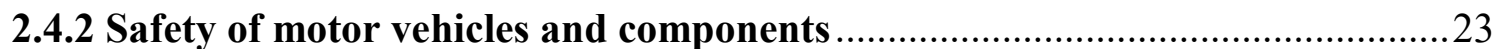

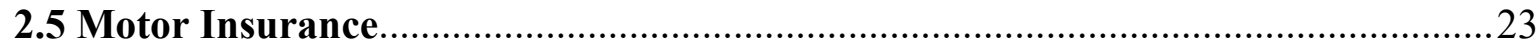

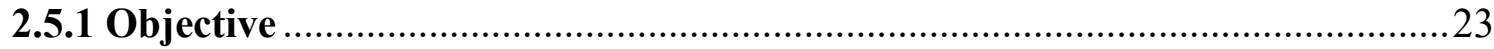

2.5.2 Scope

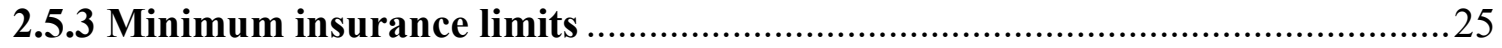

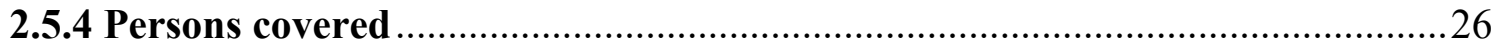

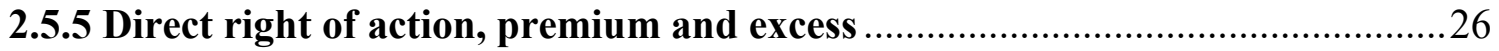

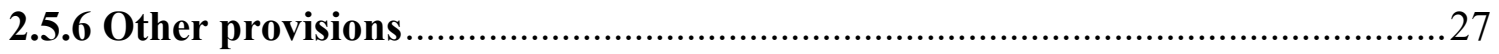

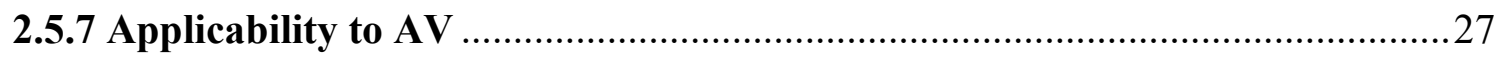

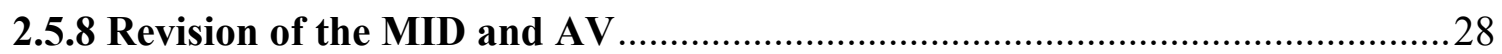

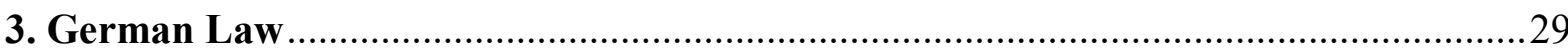

3.1 Third-party liability of the vehicle's keeper and driver ......................................2.

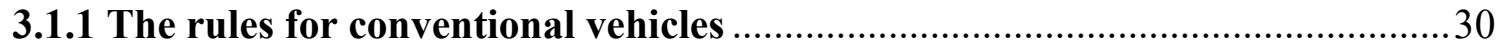

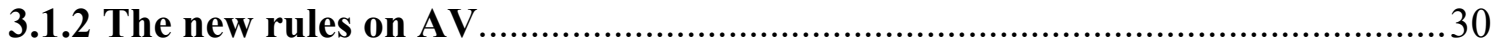

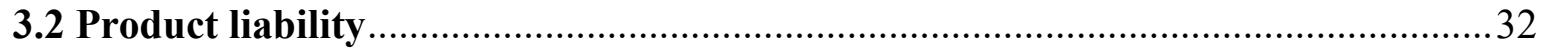

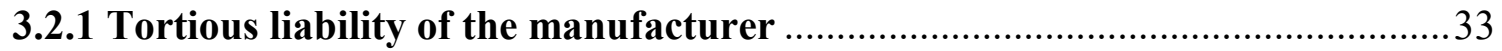

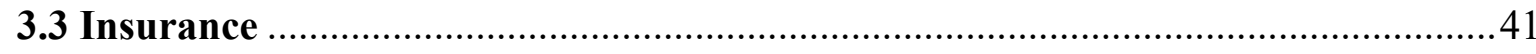

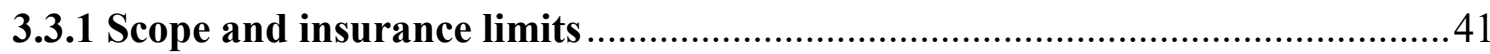




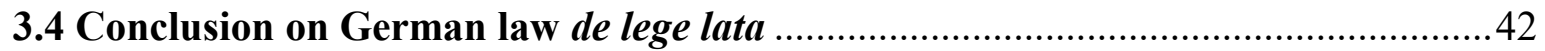

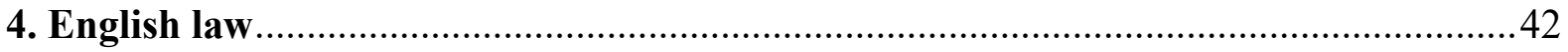

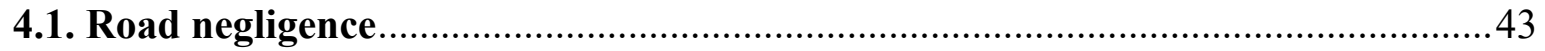

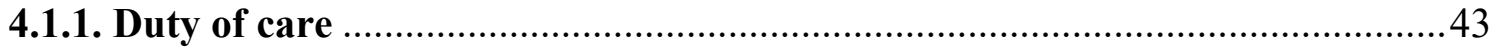

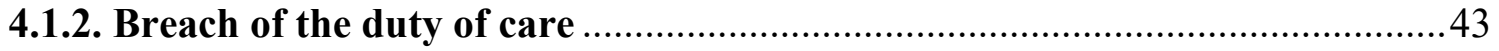

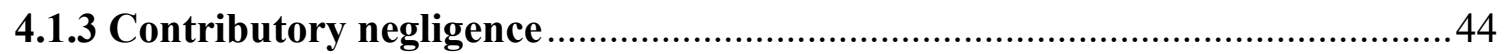

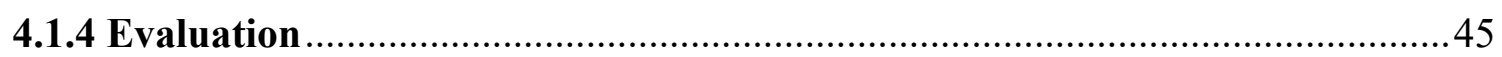

4.2 Insurance

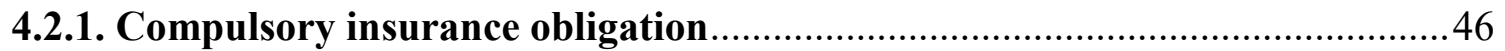

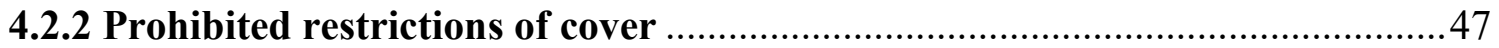

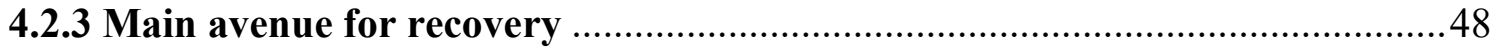

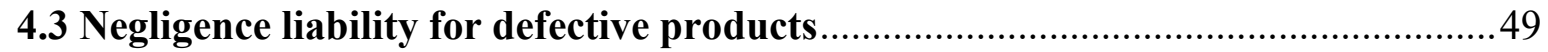

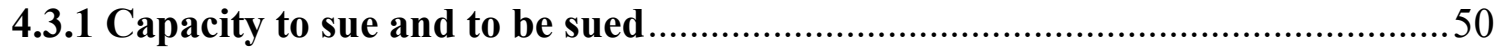

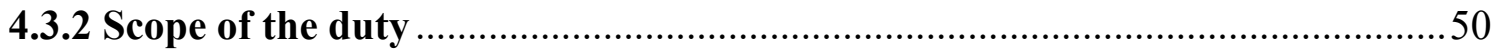

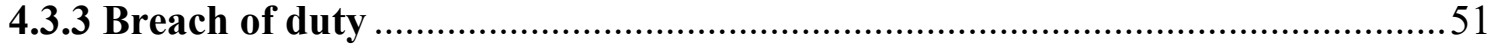

4.3.4 Damage

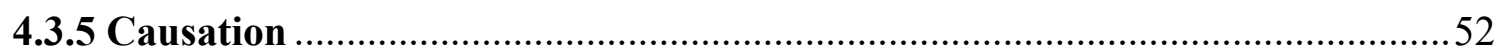

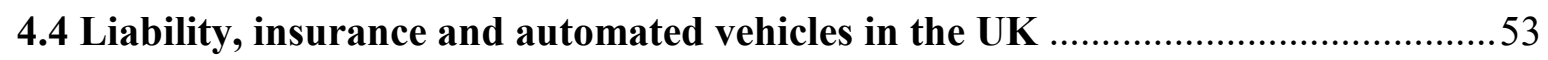

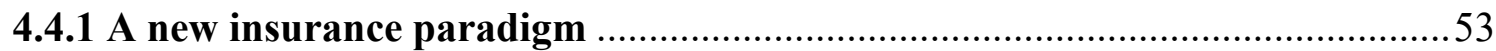

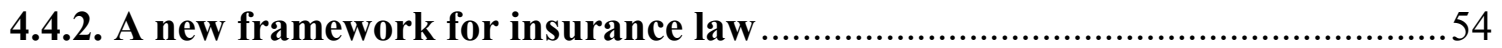

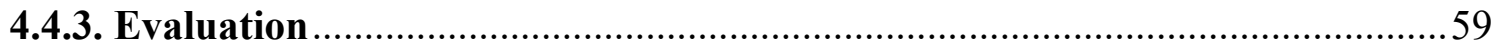

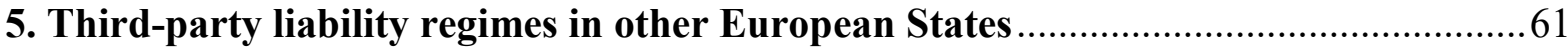

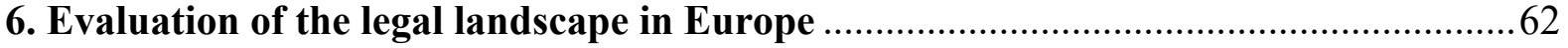

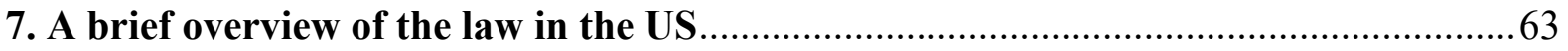

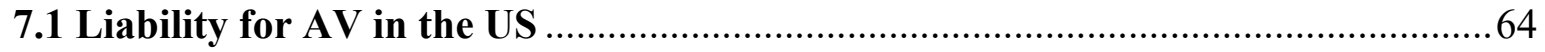

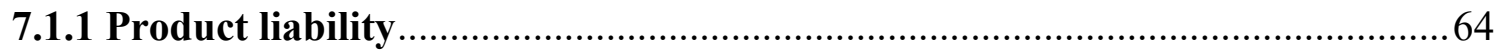




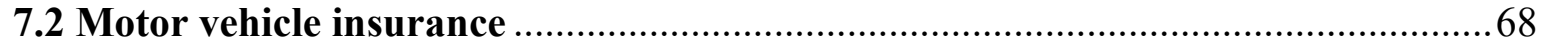

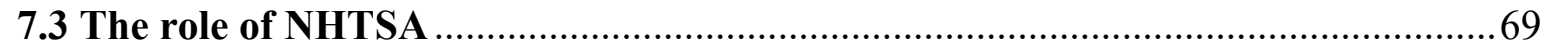

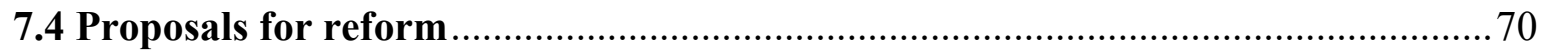

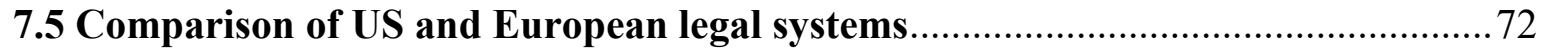

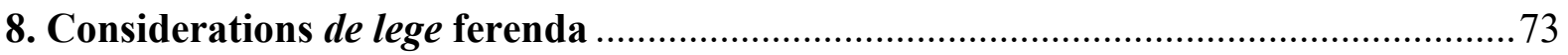

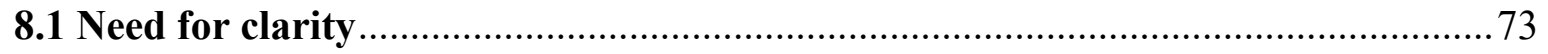

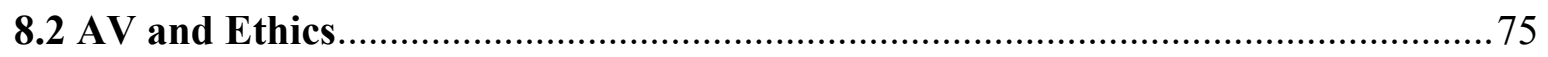

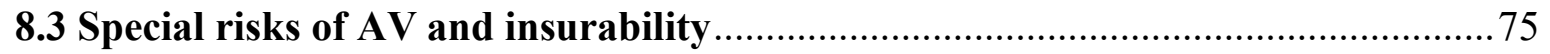

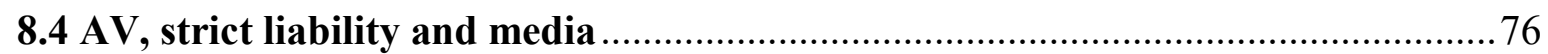

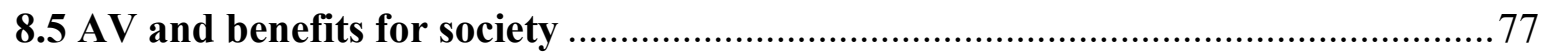

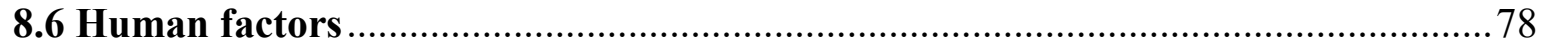

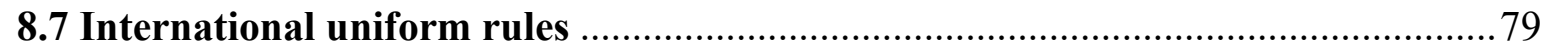

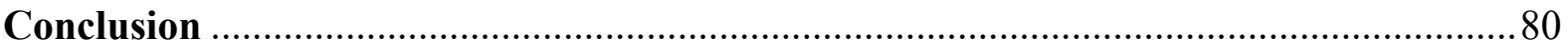

\section{Introduction: Technical parameters and automation levels of AV}

Automated vehicles (AV), commonly known as self-driving cars, are most probably the future of the car industry and driving. They are expected to dramatically decrease accidents and make roads safer, given that $94 \%$ of grave accidents are due to human error, while at the same time reduce significantly traffic congestion, driving costs and $\mathrm{CO}_{2}$ emissions. ${ }^{2}$

AV are the result of combining and integrating multiple sensors into a single system that help the vehicle "understand" the environment it is moving and adjust its road behaviour thereon ${ }^{3}$. They combine sensors and software to control, navigate, and drive the vehicle. ${ }^{4}$ Some of these sensors are already in use, e.g. satellite-navigation sensors and ultra-sonic sensors used to detect obstacles in the immediate vicinity of the vehicle. However, they are currently being used either isolated from each other or combined in low-level automation mode, just assisting the human driver, e.g. lane centring assist systems or adaptive cruise control systems. New

\footnotetext{
${ }^{2}$ See e.g. Automated vehicles for safety, NHTSA, https://www.nhtsa.gov/technology-innovation/automatedvehicles-safety (last visited on July 31, 2019) and Pete Goldin, 10 Advantages of Autonomous Vehicles (Feb. 20, 2018) http://www.itsdigest.com/10-advantages-autonomous-vehicles (last visited July 31, 2019).

${ }^{3}$ See e.g. Christian Gilbertsen, Here's how the sensors in autonomous cars work, THE DRIVE (Mar. 27, 2017) http://www.thedrive.com/tech/8657/heres-how-the-sensors-in-autonomous-cars-work (last visited July 31, 2019). ${ }^{4}$ Self-Driving Cars Explained https://www.ucsusa.org/clean-vehicles/how-self-driving-carswork\#.W2xOmSQzapo (last visited July 31, 2019).
} 
sensors are also expected to be widely introduced, such as Lidar, which use light beams to exactly identify obstacles around the car.

Thus, there are different levels of automation, which vary from merely assisting the human driver to driverless operation. SAE International, a global association of engineers and related technical experts in the aerospace, automotive and commercial-vehicle industries, ${ }^{5}$ has developed a widely recognised, six-class taxonomy of AV: ${ }^{6}$

\section{$\underline{\text { The human driver performs all or part of the Dynamic Driving Task (DDT) }}{ }^{7}$}

Level 0 - No Automation: The human driver performs the entire DDT.

Level 1 -Driver Assistance: The driving automation system executes, in a sustained manner and as specified in the vehicle's Operational Design Domain (ODD) ${ }^{8}$, either the lateral (steering) or the longitudinal (acceleration/deceleration) vehicle motion, while the driver performs the remainder of the DDT.

Level 2 - Partial Automation: The driving automation system executes, in a sustained and ODD-specific manner, both the lateral and longitudinal vehicle motion, while the driver completes the subtask of the Object and Event Detection Response ${ }^{9}$ and supervises the driving automation system.

The Automated Driving System $(\mathrm{ADS})^{10}$, while engaged, performs the entire DDT

Level 3 - Conditional Automation: The ADS performs, in a sustained and ODDspecific way, the entire DDT, while the human driver has the role of the fallbackready user, i.e. she is receptive to intervene and respond appropriately following ADS-issued requests or DDT performance-relevant system failures.

\footnotetext{
${ }^{5}$ http://www.sae.org/about/ (last visited July 31, 2019).

6 Taxonomy and Definitions for Terms Related to Driving Automation Systems for On-Road Motor Vehicles, at 19 (Jan. 16, 2014, latest revised June 15, 2018). See general info thereon https://www.sae.org/standards/content/j3016_201806/ (last visited July 31, 2019).

${ }^{7}$ The Dynamic Driving Task (DDT) comprises all real-time operational and tactical functions required to operate a vehicle in on-road traffic, e.g. steering, acceleration/deceleration, monitoring the driving environment etc. Strategic functions, such as trip scheduling and selection of destinations and waypoints, are not included in the DDT. See definition in SAE Standard J3016_201806, supra note 6, para.3.13.

${ }^{8}$ The Operational Design Domain (ODD) are the operating conditions under which a given driving automation system or feature thereof is specifically designed to function - see definition in SAE Standard J3016_201806, supra note 6, para.3.22.

${ }^{9}$ The Object and Event Detection Response (OEDR) is comprised by the subtasks of the Dynamic Driving Task (DDT) that include monitoring the driving environment (detecting, recognizing, and classifying objects and events and preparing to respond as needed) and responding appropriately to such objects and events, i.e., as needed to complete the DDT and/or DDT fallback - see definition in SAE Standard J3016 201806, supra note 6, para.3.20. The DDT fallback is the response by the user to either perform the DDT or achieve a minimal risk condition after a malfunction has occurred regarding the performance of the DDT or if the vehicle has exited Operational Design Domain (ODD), or the response by an Automated Driving System to achieve minimal risk condition, given the same circumstances - see definition in SAE Standard J3016 201806, supra note 6, para.3.14.

${ }^{10}$ Automated Driving System (ADS) means the hardware and software that are collectively capable of performing the entire DDT on a sustained basis, regardless of whether it is limited to a specific operational design domain (ODD); this term is used specifically to describe a level 3, 4, or 5 driving automation system - see definition in SAE Standard J3016_201806, supra note 6, para.3.2.
} 
Level 4 - High Automation: The ADS performs, in a sustained and ODD-specific way, the entire DDT and DDT fallback.

Level 5 - Full Automation: The ADS performs, in a sustained and unconditional way the entire DDT and DDT fallback.

AV are complex systems comprised of sophisticated hardware and software components. ${ }^{11}$ Moreover, highly AV are non-deterministic, in the sense that their behaviour depends on the input they receive from their sensors, which is combined with learning algorithms that enable modification of their current behavior. As a result, AV can act upon their environment without being fully controlled by a human being, while their actions and the potential consequences are not fully defined and predictable when they are taken into use. ${ }^{12}$

The above-mentioned elements pose great legal challenges also from a liability perspective. Traditionally, the driver can fully control the vehicle while driving and this is also reflected in current liability rules on traffic accidents: liability rests with the driver and only exceptionally with the vehicle manufacturer. However, this situation is about to change with $\mathrm{AV}$, in which control of the vehicle is passed from the driver to the vehicle system to the extent of the automation level employed. In this regard, it noteworthy that some manufacturers have already publicly stated that they will assume responsibility and the related liability for any accidents that may occur while their vehicles are operated in automated mode. ${ }^{13}$

Thus, the question is what liability rules apply to AV and how such liability is apportioned between the vehicle's driver and the manufacturer. The complex and non-deterministic nature of AV creates also challenges regarding the person (natural person or legal entity) to whom the behavior of the vehicle system should be attributed. ${ }^{14}$ Some of these issues have been highlighted by accidents involving vehicles operated in automated or semi-automated modes. ${ }^{15}$

To answer these questions, we examine the applicable liability rules of the European Union (EU) law, German law and UK law. Germany is the European frontrunner in enacting liability rules on $\mathrm{AV}$, while the UK followed a different approach by regulating insurance issues. Afterwards, we evaluate the current liability regime in Europe and examine potential needs for

\footnotetext{
${ }^{11}$ Martina Barbero et al., Study on emerging issues of data ownership, interoperability, (re-)usability and access to data, and liability, Final Report prepared for the European Commission by Deloitte et al., https://ec.europa.eu/digital-single-market/en/news/study-emerging-issues-data-ownership-interoperability-reusability-and-access-data-and (last visited July 31, 2019), 105 [hereinafter Study on emerging issues].

${ }^{12}$ Ibid., pp. 104-105.

${ }^{13}$ See e.g. AUDI takes lead in automated driving, despite regulatory hurdles (Sep. 18, 2018) EURACTIV.COM, http://www.euractiv.com/section/automated-vehicles/news/audi-takes-lead-in-automated-driving-despiteregulatory-hurdles/ (last visited July 31, 2019); Volvo CEO: Kirsten Korosec, We will accept all liability when our cars are in autonomous mode (Oct. 7, 2015), FORTUNE http://fortune.com/2015/10/07/volvo-liability-selfdriving-cars/ (last visited July 31, 2019).

${ }^{14}$ Study on emerging issues, supra note $11,104$.

${ }^{15}$ See e.g. Dana Hull and Ryan Beene, A Timeline of the Tesla Autopilot Crash Investigation (Apr. 13, 2018, 1:47 AM GMT+3) BLOOMBERG, https://www.bloomberg.com/news/articles/2018-04-12/a-timeline-of-the-teslaautopilot-crash-investigation (last visited July 31, 2019); Sam Levin and Julia Carrie Wong, Self-driving Uber kills Arizona woman in first fatal crash involving pedestrian (Mar. 19, 2018, 22:48), THE GUARDIAN, https://www.theguardian.com/technology/2018/mar/19/uber-self-driving-car-kills-woman-arizona-tempe (last visited July 31, 2019).
} 
amendment of the existing rules. Our overarching aim is to contribute to the discussions taking place globally on how to regulate civil liability arising from the use of AV.

Our analysis will start with pertinent provisions of international law, because they affect the content of both EU and national laws.

\section{International law}

In international law, there are no uniform liability rules. However, there are harmonized technical and traffic rules, which could influence liability, especially in determining eventual negligence of the driver and the manufacturer.

\subsection{Technical rules}

International technical rules have been developed in the framework of the United Nations Economic Commission for Europe (UNECE), which was set up in 1947 by the UN Economic and Social Council (ECOSOC). ECE facilitates greater economic integration and cooperation among its member countries and promotes sustainable development, also through negotiation of international legal instruments. Although UNECE's major aim is to promote pan-European economic integration, it includes States from North America, including the USA, and Asia, while any UN Member State may participate thereto. ${ }^{16}$ The UNECE technical rules, also known as UN Regulations, regard the type approval of vehicles and contain technical requirements, according to which road vehicles may be permitted to traffic. ${ }^{17}$

The legal basis of these rules is mainly the so called ' 1958 Agreement', ${ }^{18}$ to which such technical requirements are annexed. The 1958 Agreement provides that State parties thereto mutually recognise the type approvals that are made according to the UNECE Regulations. New Regulations and amendments to Regulations in force are adopted by a majority of two thirds of the contracting parties present. For a State Party to avoid being bound by a new Regulation or an amendment, it has to notify disagreement within six months from its adoption; otherwise the Regulation becomes binding. However, if more than a third of the contracting parties object to the Regulation, it does not come into force.

The technical rules are prepared by the World Forum for Harmonization of Vehicle Regulations (WP 29), which is a permanent working party in the institutional framework of the United Nations with a specific mandate and rules of procedure. It works as a global forum allowing open discussions on motor vehicle regulations.

\footnotetext{
16 https://www.unece.org/mission.html (last visited July 31, 2019). Currently ECE has 56 Member States, see http://www.unece.org/oes/nutshell/member_States_representatives.html (last visited July 31, 2019).

${ }^{17} \mathrm{https}$ ://www.unece.org/mission.html (last visited July 31, 2019).

18 Agreement concerning the Adoption of Uniform Conditions of Approval and Reciprocal Recognition of Approval for Motor Vehicle Equipment and Parts, Mar. 20, 1958, 335 U.N.T.S. 211, which under the current third revision of Oct. 20, 2017, has the title "Agreement concerning the Adoption of Harmonized Technical United Nations Regulations for Wheeled Vehicles, Equipment and Parts which can be Fitted and/or be Used on Wheeled Vehicles and the Conditions for Reciprocal Recognition of Approvals Granted on the Basis of these United Nations Regulations, C.N.314.2017.TREATIES-XI.B.16.
} 
Current ECE rules do not provide for AV. Nonetheless, much work is ongoing and many ECE working groups are working on various parameters of $\mathrm{AV}$, preparing rules and recommendations. ${ }^{19}$

\subsection{Harmonized traffic rules}

Harmonized traffic rules that were developed in the framework of UNECE can be found in the 1949 Geneva Convention and its successor, the 1968 Vienna Convention. As a guardian to these conventions serves the UNECE 'Global Forum for Road Traffic Safety (WP.1)'. ${ }^{20}$

The 1949 Geneva Convention ${ }^{21}$ establishes uniform international traffic rules, to promote the development and safety of international road traffic. Art. 8(1) and (5) of the Convention provides that every vehicle must have a driver, who must be able to control it at all times.

The 1968 Vienna Convention ${ }^{22}$ replaced the 1949 Geneva Convention. Many States, including the US, Canada and Ireland are only party to the latter. ${ }^{23}$ However, most EU-Member States are parties to the 1968 Vienna Convention. ${ }^{24}$ Just like its predecessor, Art. 8(1) and (5) of the 1968 Vienna Convention provides that a driver should always control fully the vehicle and must be able to control it.

Nonetheless, in 2016, the 1968 Vienna Convention was amended, to allow automated driving technologies that transfer driving tasks to the vehicle, provided that these technologies conform to the UNECE Regulations or can be overridden or switched off by the driver. ${ }^{25}$ However, a human driver is still required, while it is not clear if the driver may engage in parallel activities while the automated driving mode is engaged.

Furthermore, the Global Forum for Road Traffic Safety (WP.1) has adopted a resolution on the deployment of highly and fully automated vehicles in road traffic. ${ }^{26}$ The objective of the resolution is, among others, to guide Contracting Parties on the safe deployment of AV in road traffic and to provide complementary recommendations supporting the road safety principles of the 1949 and 1968 Conventions on Road Traffic. ${ }^{27}$ Section 4 of the Resolution provides that AV should:

\footnotetext{
${ }^{19}$ RELEVANT UNECE ACTIVITIES ON AUTOMATED DRIVING, http://www.unece.org/trans/themes/transthemeits/automated-vehicles/automated-driving.html (last visited July 31, 2019).

${ }^{20} \mathrm{https} / /$ www.unece.org/trans/roadsafe/rsabout.html (last visited on July 31, 2019).

${ }^{21}$ Convention on Road Traffic, Sep. 19, 1949, 3 U.S.T. 3008, 125 U.N.T.S. 3.

${ }^{22}$ Convention on Road Traffic, Nov. 8, 1968, 1042 U.N.T.S. 17.

23 See the signatories at https://treaties.un.org/doc/Publication/MTDSG/Volume\%20I/Chapter\%20XI/xi-b1.en.pdf (last visited Dec. 2, 2019).

24 See list of contracting parties at https://treaties.un.org/doc/Publication/MTDSG/Volume\%20I/Chapter\%20XI/XI-B-19.en.pdf (last visited Dec 2, 2019).

${ }^{25}$ See Article 8 para. 5bis and Article 39 para. 1 of the amended Convention.

${ }^{26}$ Report of the Global Forum for Road Traffic Safety on its seventy-seventh session ECE/TRANS/WP.1/165, Annex 1, Oct. 3, 2018, http://www.unece.org/fileadmin/DAM/trans/doc/2018/wp1/ECE-TRANS-WP1-165e.pdf (last visited July 31, 2019) [hereinafter UNECE Resolution].

${ }^{27}$ UNECE Resolution Section 2.
} 
(a) Make road safety a priority;

(b) Monitor and safely interact with the surrounding traffic environment;

(c) Endeavour to safely tolerate errors of the vehicles' users, inside and outside of the vehicle, and of other road users in order to minimize potential effects of such errors;

(d) Comply with traffic rules,

(e) Only operate within their Operational Driving Domain;

(f) Be capable of achieving a state that maximizes road safety when a given trip cannot or should not be completed;

(g) React to unforeseen situations in a way that minimizes danger to the vehicle's users and other road users;

(h) Communicate with their users and other road users, in a clear, effective and consistent way, by providing sufficient information about their status and intention, and enabling an appropriate interaction;

(j) Operate in a way that enables verification as to whether or not they are or were performing dynamic control; and

(k) Enable their deactivation in a safe manner.

The resolution contains also recommendations to users of $\mathrm{AV}$, such as to be aware of the proper use of the AV before starting a journey, meet the requirements and procedures for safe use, etc. ${ }^{28}$ In addition, the resolution contains recommendations to governments, e.g. to raise public awareness and adopt policies on data safety and cyber security. ${ }^{29}$ The recommendations of the resolution are not legally binding; however, they provide useful guidance on the standard of care expected by manufacturers and users.

\section{EU law}

In EU law there are rules on product liability and safety. These rules have the form of Directives. According to Art. 288(3) of the Treaty on the Functioning of the EU, "a Directive shall be binding, as to the result to be achieved, upon each Member State to which it is addressed, but shall leave to the national authorities the choice of form and methods". This means that each EU Member State undertakes to incorporate the provisions of the Directive into its national legal system through national harmonizing legislation.

\subsection{No special rules on $\mathrm{AV}$}

At EU level, there are no harmonized liability provisions on AV. At present, the European Commission focuses on issues of interconnectivity and interoperability between vehicles themselves, and between vehicles and road infrastructure. ${ }^{30}$

\footnotetext{
${ }^{28} I d$., Section 5.

${ }^{29} I d$., Section 6 .

${ }^{30}$ See European Commission, A European strategy on Cooperative Intelligent Transport Systems, a milestone towards cooperative, connected and automated mobility COM(2016) 766 final (Nov. 30, 2016).
} 


\subsection{Product liability- Directive 85/374/EEC}

Product liability in the EU is regulated by Directive 85/374/EEC ${ }^{31}$ (Product Liability Directive - PLD). The PLD contains generic rules, which apply also to AV. The Directive's provisions on the liability of the producer are of mandatory nature and cannot be derogated by contractual clauses (Art. 12).

\subsubsection{Objective and level of harmonization}

The PLD aims at a fair apportionment of the risks inherent in modern technological production $^{32}$. As a result, it is a full harmonization Directive, which means that EU Member States (MS) are not allowed to lay down, in their harmonization legislation, more stringent rules to protect victims.

However, Art. 13 PLD clarifies that the Directive does not affect contractual or non-contractual liability or special product-liability regimes that were in force at the date when the PLD was notified (7 August 1985). In that case, these rules remain unaffected and can form a separate legal base for compensation claims (Art. 13). ${ }^{33}$ Nonetheless, MS may not establish or maintain a general product-liability regime that deviates from the PLD provisions. ${ }^{34}$

The Court of Justice of the EU (CJEU), former European Court of Justice (ECJ), has underlined that the PLD seeks to achieve, in the matters regulated by it, complete harmonization of the laws, regulations and administrative provisions of the Member States; however, as can be seen from its eighteenth recital, the PLD seeks to harmonize exhaustively only the liability aspects for defective products regulated by it. ${ }^{35}$

For AV, the Directive's full harmonization character entails that any regulatory shortcomings in the system of product liability of the EU Member States cannot be overcome by laying down new pieces of national legislation. New rules could be established only if the EU amends or repeals the Directive. An alternative possibility might be that national courts adopt the interpretation of the existing national tort rules on product liability.

\footnotetext{
${ }^{31}$ Council Directive 85/374/EEC of 25 July 1985 on the approximation of the laws, regulations and administrative provisions of the Member States concerning liability for defective products, 1985 O.J. (L 210), 29 - 33 [hereinafter $P L D]$. According to the Consolidated Version of the Treaty on the Functioning of the European Union, Art. 288 para. 3, May 9, 2009, 2008 O.J. (C 115) 47 [hereinafter TFEU] "a Directive shall be binding, as to the result to be achieved, upon each Member State to which it is addressed, but shall leave to the national authorities the choice of form and methods". This means that each EU Member State undertakes to incorporate the provisions of the Directive through national harmonizing legislation.

${ }^{32}$ PLD Recitals (2) and (7).

${ }^{33}$ See CJEU Case C-402/03 Skov Æg v Bilka Lavprisvarehus A/S and Bilka Lavprisvarehus A/S v J. Mikkelsen and M.D. Nielsen Judgment of 10 Jan. 2006, 2006 EC.R. I-199, which held that the PLD precludes a national rule under which the supplier is answerable, beyond the cases listed exhaustively in Article 3 para. 3 thereof, for the no-fault liability which the PLD establishes and imposes on the producer; yet it does not preclude a national rule under which the supplier is answerable without restriction for the producer's fault-based liability.

${ }^{34}$ ECJ Case C-183/00, González Sánchez v Medicina Asturiana SA, 2002 EC.R.. I-03901, paras 32-33.

${ }^{35}$ CJEU Case C-621/15, N. W and Others v Sanofi Pasteur MSD SNC and Others, http://curia.europa.eu, paras 20-21; CJEU Case C-310/13, Novo Nordisk Pharma GmbH v S, http://curia.europa.eu, paras. 23-24;.
} 


\subsubsection{Elements of liability}

The Directive imposes strict liability on the 'producer' for 'damages' caused by a 'defect' in its 'product' (Art. 1).

\subsubsection{1 'Product'}

A 'product' under the Directive is any movable, even though incorporated into another movable or into an immovable (Art. 2, first sentence). 'Product' includes electricity (Art. 2, third sentence).

\subsection{Software as a 'product'}

It is disputed whether the PLD covers software. As long as software is embedded in movables, software can be seen as a 'product'. ${ }^{36}$ For non-embedded software, the prevailing view in many $\mathrm{MS}^{37}$ considers it a 'product': on the one hand, there is no distinction in the PLD between material substance and information; on the other hand, the objective of the PLD to protect end users would be undermined if the claimant had to prove that the damage came from a hardware defect and not from a software defect, because the damaging effect is the same for claimants in both cases. ${ }^{38}$

An extensive interpretation of 'product' to cover software could be supported by the fact that electricity, which is also intangible, is a 'product'. Besides, at the time of the drafting and negotiation of the Directive such technological advances could hardly have been foreseen. Therefore, it can be argued that an evolutive, wide interpretation of 'product' is necessary, to align the PLD with modern needs. However, the counter-argument is that we need to maintain legal certainty and not disturb the balance of interests stricken by the PLD.

The issue is unclear and is being currently debated in the framework of the Directive's evaluation and possible amendment. ${ }^{39}$

If software is not covered by the PLD, then the PLD does not preclude national legislation, which would extend product liability rules to software. ${ }^{40}$

\footnotetext{
${ }^{36}$ Study on emerging issues (supra note 11), 119; Peter Rott, Rechtspolitischer Handlungsbedarf im Haftungsrecht, insbesondere für digitale Anwendungen, May 4, 2018, at 15, https://www.vzbv.de/sites/default/files/downloads/2018/05/04/gutachten handlungsbedarf im haftungsrecht.pd f (last visited July 31,2019 ).

${ }^{37}$ Rott (supra note 36), 16. See also K. Alheit, The applicability of the EU Product Liability Directive to software, 34 The COMParative and International LaW Journal OF SOUthern AFrica, 188, 194-195 (2001), with further citations.

${ }^{38}$ Rott (supra note 36), 16.

${ }^{39}$ See European Commission, Evaluation of the Directive 85/374/EEC concerning liability for defective products

- Roadmap, Sep. 27, 2016, http://ec.europa.eu/DocsRoom/documents/18842/ (last visited 31 July 2019).

${ }^{40}$ Rott (supra note 36$), 19$.
} 


\subsection{Consequences for AV}

$\mathrm{AV}$ as such are tangible movables and are undoubtedly 'products'. However, the situation regarding software used in AV is less certain. Such uncertainty in enhanced in cases of software updates and functionality revisions, especially when these are conducted by third parties. ${ }^{41}$ To the extent that software updates can be seen as a service, they will not be covered by the PLD, which regulates only 'products'. ${ }^{4}$

We subscribe to the view that the PLD covers software necessary for the vehicle operation, e.g. navigation, steering and breaking software, including software updates. ${ }^{43}$ However, other types of software, such as entertainment software provided by third parties are not necessarily covered. In any case, to enhance legal certainty, an explicit clarification in the PLD through an amendment is recommended. ${ }^{44}$

\subsubsection{Persons liable}

Art. 3(1) PLD clarifies that liable 'producers' are the manufacturer of the end product, the component manufacturer, the producer of any raw material, as well as any person who, by putting his/her name, trade mark or other distinguishing feature on the product presents himself as its producer. Furthermore, the importer of the product in the EU is also deemed a 'producer' [Art. 3(2)].

Where the producer of the product cannot be identified, each supplier of the product is treated as its producer, unless he/she informs the injured person, within a reasonable time, of the identity of the producer or of the person who supplied him/her with the product. The same applies, in the case of an imported product, if this product does not indicate the identity of the importer referred to in Art. 3(2), even if the name of the producer is indicated [Art. 3(3)]. The supplier, against whom proceedings are brought by an injured person, has to inform the latter, on his/her own initiative and promptly, of the identity of the producer or his/her own supplier - a mere denial of the supplier that he/she is not the producer is insufficient. ${ }^{45}$

All these persons are liable jointly and severally, without prejudice to the provisions of national law concerning the rights of contribution or recourse (Art. 5). The objective of these provisions is to enhance consumer protection by increasing the number of the potentially liable persons. ${ }^{46}$

\footnotetext{
${ }^{41}$ Study on emerging issues (supra note 11), 122.

${ }^{42} I d$.

${ }^{43}$ Rott (supra note 36$), 18$.

${ }^{44}$ See also Rott (supra note 36), 18; Study on emerging issues (supra note 11), 113.

${ }^{45}$ ECJ Judgment of 2 Dec. 2009, case C-358/08 Aventis Pasteur, ECLI:EU:C:2009:744, paras 57-58.

${ }^{46}$ PLD Recitals (4) and (5).
} 
The CJEU has clarified that the PLD regulates only the liability of producers for defective products and does not cover the liability of service providers who use defective products. ${ }^{47}$

Regarding AV, the manufacturers of the vehicles as well as their importers into the EU will be liable. Such liability will include malfunctions of embedded software. ${ }^{48}$ Furthermore, the manufacturer of such software will also be liable, especially regarding safety critical software, such as navigation, steering and breaking software. ${ }^{49}$ Liability of suppliers of AV under the PLD will have limited importance in practice, since in the car industry the identity of the endproduct manufacturer or the importer is known.

In addition, the above-mentioned judgment of the CJEU on non-liability of service providers under the PLD ${ }^{50}$ makes clear that persons who provide services using AV, e.g. taxi services or ride-hailing services, will not be liable.

It has been suggested that the PLD contains a limited list of liable persons, which undermines the protection of victims of AVs, since parties like rental companies and other service providers, pure developers of the operating technology and testing companies are not covered by the PLD. ${ }^{51}$ Nevertheless, it has to be considered that the PLD is the result of balance of interests, as its preamble clearly indicates, and does not aim to offer complete protection in all cases. National (negligence) legal regimes that operate side-by-side with the PLD could offer additional protection.

\subsubsection{3 'Defect'}

\subsection{Safety expectations}

According to Art. 6(1) PLD, a product is 'defective', when it does not provide the safety which a person is entitled to expect, taking all circumstances into account, including (a) the presentation of the product, (b) the use to which it could reasonably be expected that the product would be put, (c) the time when the product was put into circulation. Art. 6(2) PLD clarifies that a product shall not be considered defective for the sole reason that a better product is subsequently put into circulation. The CJEU has ruled that a product is put into circulation when it is taken out of the manufacturing process operated by the producer and enters a marketing process in the form in which it is offered to the public in order to be used or

\footnotetext{
${ }^{47}$ CJEU Case C-495/10, Centre hospitalier universitaire de Besançon v Thomas Dutrueux and Caisse primaire d'assurance maladie du Jura, 2011 E.C.R. I-14155.

${ }^{48}$ Rott (supra note 36), p. 21.

${ }^{49}$ Ibid.

${ }^{50}$ See supra note 47.

${ }^{51}$ Kyriaki Noussia, Autonomous vehicles: Legal considerations and dilemmas, in INSURTECH: A LEGAL AND REGULATORY VIEW 253, 259 (Pierpaolo Marano and Kyriaki Noussia eds., 2019)
} 
consumed. ${ }^{52}$ The time that the product was put into circulation is critical, since 'producers' are only liable for defects that existed at that time. ${ }^{53}$

Hence, the PLD covers design defects (i.e. a whole production is defective) and manufacturing defects (i.e. isolated products of a production series are defective). It also establishes a duty to warn on dangers of the product, albeit to a limited extent, i.e. until the product has been put into circulation. However, the PLD lays down no duty to warn on dangers after the product has been put into circulation or to recall defective products. These duties are foreseen in separate pieces of European legislation on product safety, which do not impose EU-wide liability rules. ${ }^{54}$

Recital (6) of the PLD preamble makes clear that, to protect the physical well-being and property of the consumer, the defectiveness of the product should be determined by reference to the lack of the safety which the public at large is entitled to expect and not to its fitness for use. Therefore, the safety-expectations test is judged objectively rather than by reference to the expectations of the specific user. ${ }^{55}$ In addition, the PLD establishes a duty to put into circulation products that are reasonably safe, taking into account all circumstances - not products that are absolutely safe. ${ }^{56}$ In this regard, some national courts have referred to a risk-benefit analysis of the product's characteristics, taking into account the kind and the extent of the risks connected to the use of the product, the possibility that such risks materialize, the cost of additional safety measures and the benefits from the use of the product. ${ }^{57}$

At the same time, safety is assessed by excluding any misuse of the product not reasonable under the circumstances. ${ }^{58}$ Consequently, the reasonable safety expectations of the user encompass cases of foreseeable product misuse. Producers must consider foreseeable product misuse both when designing the product and when issuing instructions and warnings. ${ }^{59}$

Moreover, the CJEU has ruled that, where it is found that products belonging to the same group or forming part of the same production series, such as pacemakers and implantable cardioverter

\footnotetext{
${ }^{52}$ CJEU Case C-127/04 Declan O'Byrne v Sanofi Pasteur MSD Ltd and Sanofi Pasteur SA, 2006 E.C.R. I-01313.

${ }^{53}$ PLD Art. 7(b), which precludes the producer's liability for defects that did not exist at the time the product was put into circulation.

${ }^{54}$ See Directive 2001/95/EC of the European Parliament and of the Council of 3 December 2001 on general product safety, Art. 5, 2002 O.J. (L 11); Directive 2007/46/EC of the European Parliament and of the Council of 5 September 2007 establishing a framework for the approval of motor vehicles and their trailers, and of systems, components and separate technical units intended for such vehicles, Art. 32, 2007 O.J. (L 263 ) 1.

${ }_{55}$ See Bundesgerichtshof [BGH] [Federal Court of Justice] June 16, 2009 (Airbag), NEUE JURISTISCHE

WOCHENSCHRIFT [NJW] 2952 (para. 12), 2009 (Ger.).

${ }^{56}$ RaChel Mulheron, PrinciPles of Tort Law, Defective Products - Online Content, 196 (2016) https://www.cambridge.org/files/6614/7610/6091/Defective_products_Mulheron.pdf (last visited July 22, 2019). ${ }^{57}$ Wilkes v DePuy International Limited [2016] EWHC 3096, paras 65-67 (Eng.), which nonetheless rejects the risk-utility test as applied in the US; Bundesgerichtshof [BGH] [Federal Court of Justice] June 16, 2009 (Airbag), NeuE JURISTISCHE WOCHENSCHRIFT [NJW] 2952 (paras. 16-18), 2009 (Ger.).

${ }^{58}$ PLD Recital (6).

${ }^{59}$ Martin Ebers, Autonomes Fahren: Produkt und Produzentenhaftung, in: AUTONOMEs FAHREN 93, 112-113

(Bernd H. Oppermann and Jutta Stender Vorwachs eds., 2017); Rott, supra note 36, 24.
} 
defibrillators, have a potential defect, such a product may be classified as defective without there being any need to establish that that product has such a defect. ${ }^{60}$

\subsection{Safety expectations of AV users}

The 'reasonable' expectations of users of AV may not always be easy to define. Since the main promise of AV technology is enhanced safety, users are entitled to expect that AV will be safer than ordinary cars. ${ }^{61}$ It has been suggested that AV should be able to deal autonomously with all situations that could occur during the autonomous phase of driving. ${ }^{62}$ They should also be in position to recognize wrongful behavior of other road users and adjust their own behavior to prevent an accident. ${ }^{63}$

According to a mixed criterion, the AV safety should be compared, at first stage and as a minimum, to that of a reasonable driver. At a second stage, there should be a comparison between the accident rate of conventional vehicles and the accident rate of a particular fleet of AVs. ${ }^{64}$

Moreover, as producers gain more experience and technology progresses, the reasonable safety expectations of the users will increase. After a certain period, a system may not correspond to such safety expectations, although the failure rate is lower than that of humans. ${ }^{65}$

In any case, the thorough examination of the circumstances of each case is necessary. Advertising statements combined with instructions and warnings in user manuals are expected to play a crucial role.

In advertising, producers should be careful not to raise exaggerated expectations by using terms such as 'autonomous' or 'auto pilot', which could be misunderstood and lead to product misuse. ${ }^{66}$ In the case of semi-autonomous vehicles, producers should take into account that

\footnotetext{
${ }^{60}$ CJEU Joined Cases C-503/13 and C-504/13, Boston Scientific Medizintechnik GmbH v AOK Sachsen-Anhalt

- Die Gesundheitskasse and Betriebskrankenkasse RWE, http://curia.europa.eu.

${ }^{61}$ Ebers, supra note 59, 108.

${ }^{62}$ Id., 104.

63 Id., 105.

${ }^{64}$ Patti, Francesco Paolo Patti, The European Road to Autonomous Vehicles, 43 Fordham Int'1 L.J. 125, 161 (2019).

${ }^{65} \mathrm{Ib}$.

${ }^{66} I d$., 112. Compare the use of the term 'auto pilot' in Tesla's semi-automated vehicles. In Germany, the Federal Motor Transport Authority found such terms misleading and asked Tesla to stop using them - see Germany says Tesla should not use 'Autopilot' in advertising, REUTERS (Oct. 16, 2016, 4:30 PM), https://uk.reuters.com/article/uk-tesla-germany-idUKKBN12G0KQ (last visited July 31, 2019). More recently, in the US, two consumer advocacy groups have requested the Federal Trade Commission to investigate Tesla's advertising practices consisting in the use of terms such as 'auto pilot' and 'full self-driving hardware' in Level 2 vehicles - see Jason Torchinsky, Consumer Group Says Tesla's Autopilot Is 'Deceptive, ' Calls For Investigation, JALOPNIK (May 23, 2018, 12:07 PM), https://jalopnik.com/consumer-group-says-teslas-autopilotis-deceptive-call-1826249830 (last visited July 31, 2019).
} 
drivers may use the vehicles in ways they were not meant to be used, e.g. by relying too much on the driver-assistance systems. ${ }^{67}$

As to instructions and warnings, producers of AV should take all effort to ensure that the user can operate the vehicle safely. Therefore, they have to inform the user on: (i) the exact purposes for which the AV is meant to be used, (ii) how should the system be configured and operated, (iii) the extent to which the system needs to be monitored during operation, (iv) how should the user react in case of system failure and $(\mathrm{v})$ how should the system be regularly maintained. ${ }^{68}$

Besides, foreseeable misuse could also be the attempt of third parties to unlawfully gain control of the AV. Therefore, security shortcomings of software, which could enable unlawful interference with the operation of the vehicle and result in damage, may too be considered as 'defect'.

Human factors in the human-machine interface of AV, such as warning signals and time required for the driver to take over manual control of the vehicle will also be considered in determining the legitimate safety expectations. ${ }^{69}$

In addition, given the judgment of the CJEU in the Boston Scientific Medizintechnik case, ${ }^{70}$ it is not unlikely that AV of a specific type are found defective because of defects discovered only to some of the vehicles of that type. Nonetheless, caution is required: the above-mentioned case concerned a very specific category of products and a safety problem in a particular AV may not imply the defectiveness of the entire fleet of such AV. ${ }^{71}$

\subsection{Time in which AV were 'put into circulation'}

As mentioned above, an important factor in determining defectiveness is the time in which the product was put into circulation. ${ }^{72}$

In view of the self-learning abilities of $\mathrm{AV}$, an important challenge will be to determine if the AV was 'defective' when it was put into circulation. It could be argued that safety issues created by learned behavior fall outside the scope of the PLD, unless one considers as a 'defect' the learning algorithms of the AV, especially if they do not provide adequate safeguards against potentially harmful behavior. ${ }^{73}$

In such cases, the reasonable user expectations are that the producer will take care to prevent the vehicle system from learning any dangerous behavior. As mentioned before, failure of the producer to consider cases of foreseeable product misuse may constitute a 'defect'. In self-

\footnotetext{
${ }^{67}$ Ebers, supra note 59, 112.

${ }^{68} I d ., 111$.

${ }^{69}$ See on human factors infra 7.6.

${ }^{70}$ Supra note 60.

${ }^{71}$ Patti, supra note $64,149$.

${ }^{72}$ See supra under 2.2.2.3.1.

${ }^{73}$ See Study on emerging issues, supra note 11, 121.
} 
learning systems this means that the producer should avoid that the system learns behaviors that contradict its safety purpose. ${ }^{74}$

\subsection{3 'Damage'}

'Damage' is defined in Art. 9 PLD. It includes personal damages, yet property damage is covered only under certain requirements: no damage to the defective product itself is covered, while damage to other property items requires that (a) the damage exceeds $500 €$, (b) the damaged item is of a type ordinarily intended for private use or consumption, and (c) the item was used by the injured person mainly for his/her own private use or consumption. Nonmaterial damage can be awarded according to the applicable national provisions.

Thus, pure economic loss, contrary to consequential loss, is not covered by the PLD. Recoverable damages under PLD is restricted by the full harmonization character of the PLD. ${ }^{75}$

As to the notion of 'other property items', it would cover cases of software subsequently installed. ${ }^{76}$ Moreover, Art. 16(1) PLD allows EU Member States (MS) to introduce an upper limit of the producer's liability, which cannot be lower than $€ 70$ million, for damage resulting from death or personal injury and caused by identical items with the same defect. This provision applies mainly to cases of design defects. Germany, Spain and Portugal have used such possibility. ${ }^{77}$ Nonetheless, at least in Germany, the upper limit has been criticized as not serving any purpose, given that (i) the limit has not been used in any case so far, (ii) claimants could base their claims on tort, which has no upper limit, and (c) that the non-existence of such limit in other MS has not created any problems. ${ }^{78}$

Damage to other items must exceed $500 €$. This threshold aims at avoiding litigation in an excessive number of cases ${ }^{79}$ and encourage out-of-court dispute settlement for small claims. ${ }^{80}$ The minimum limit has been implemented differently by MS. Some MS, including Germany, interpret such limit as deductible from the compensation due; other MS, such as the UK and the Netherlands, see it as a liability threshold, which once overpassed, enables the claimant to receive full compensation. ${ }^{81}$ This provision has been criticized, because, among others, it does not discourage litigation in MS that have in place a parallel, tort-based system of product liability. ${ }^{82}$

\footnotetext{
${ }^{74}$ Rott, supra note $36,34$.

${ }^{75} \mathrm{Id} ., 40$.

${ }^{76} I d ., 41$.

77 See Report from the Commission on the Application of Directive 85/374 on Liability for Defective Products, $\operatorname{COM}(2000) 893$ final (Jan. 31, 2001) [hereinafter Commission Report 2001].

${ }^{78}$ Rott, supra note $36,43$.

${ }^{79}$ PLD Recital (9).

${ }^{80}$ Commission Report 2001 (supra note 77), at 19.

${ }^{81}$ European Commission, Third report on the application of Council Directive on the approximation of laws, regulations and administrative provisions of the Member States concerning liability for defective products, COM (2006) 496 final (Sep. 14, 2006), 11. See also Rott, supra note 36, 42.

82 Rott, supra note $36,45$.
} 
Moreover, the PLD makes clear that damage to other property items is recoverable, only if these items are intended and mainly used for private purposes. Thus, the PLD will not cover damage caused by an AV to a vehicle used for professional purposes or to a building with offices.

\subsubsection{Defences}

Art. 7 PLD lays down the reasons of exoneration of the producer from its liability. These circumstances must be interpreted strictly. ${ }^{83}$ The producer is not liable if he/she can prove one of following defences:

(a) That the producer did not put the product into circulation. This is intended primarily to cover cases in which a person other than the producer has caused the product to leave the process of manufacture. ${ }^{84}$

(b) That, having regard to the circumstances, it is probable that the defect which caused the damage did not exist at the time when the product was put into circulation by the producer or that this defect came into being afterwards.

(c) That the producer neither manufactured the product for sale or any form of distribution for economic purpose, nor did it manufacture or distribute the product in the course of its business.

(d) That the defect is due to compliance of the product with mandatory regulations issued by the public authorities.

(e) That the state of scientific and technical knowledge at the time when the producer put the product into circulation was not such as to enable the existence of the defect to be discovered (state-of-the-art defence). The ECJ has clarified ${ }^{85}$ that Article 7(e) is not specifically directed at the practices and safety standards in use in the industrial sector in which the producer is operating. It does refer to the state of scientific and technical knowledge, including the most advanced level of such knowledge, at the time when the product in question was put into circulation. Second, this defence is judged objectively, considering the state of knowledge of which the producer is presumed to have been informed. Nevertheless, it is implicit in the wording of Article 7(e) that the relevant scientific and technical knowledge must have been accessible at the time when the product in question was put into circulation. Therefore, in order to have a defence under Article 7(e) PLD, the producer of a defective product must prove either that the objective state of scientific and technical knowledge, including the most advanced level of such knowledge at the time when the product in question was put into circulation, did not enable the discovery of the defect; or that such knowledge was not accessible at the time when the product in question was put into circulation.

\footnotetext{
${ }^{83}$ ECJ case C-203/09, Volvo Car Germany GmbH v Autohof Weidensdorf GmbH, 2010 E.C.R. I-10721 para. 15.

${ }^{84} \mathrm{ECJ}$, ibid, para. 16.

${ }^{85}$ ECJ case C-300/95, Commission of the European Communities v United Kingdom of Great Britain and Northern Ireland, 1997 E.C.R. I-2649, paras 26-29.
} 
It is noteworthy that MS may opt to not make available to manufacturers such defence. ${ }^{86}$ So far, five MS have used such possibility, albeit only two MS do not allow such defence in all sectors. ${ }^{87}$ Nonetheless, it has been reported that the stateof-the-art defence has had limited practical importance in Europe. ${ }^{88}$

(f) Producers of components can be exonerated, if they prove that the defect is attributable to the design of the product in which the component has been fitted or to the instructions given by the manufacturer of the product.

Moreover, the comparative or contributory negligence of the injured persons and their agents is taken into account [Art. 8(2)]. If the damage is due both to a defect in a product and to an act or omission of a third party, the producer and the third party will be held jointly liable [Art. $8(1)]$.

In the context of AV, which are technological advanced products, the state-of-the-art defence [Art. 7(e)] is expected to play a key role, despite the very high requirements for its establishment. This will have special importance in the case of learning algorithms, which might prove to be inadequate and lead to avoidable accidents. A cost-benefit analysis should be undertaken in which various factors are taken into account, such as the seriousness and the probability of risks, the expected benefits from the use of the product, the cost and feasibility of constructing a safer product; however, regarding personal injuries the risks have to be minimal. ${ }^{89}$

In addition, if certain types of AV are used only for testing and experiments, producers can invoke the defence of Art. 7(c), i.e. that they did not manufacture the product for sale or any form of distribution for economic purpose.

The comparative or contributory negligence of the user will be determined considering the user's duties regarding the selection, monitoring and operation of the AV. It has been suggested that the user should: select an AV suitable for the intended use, e.g. take into account eventual restrictions of use in specific roads only; configure the AV according to the manufacturer instructions and respect all safety precautions; monitor the system operation and maintain it according to the user manual. ${ }^{90}$

\footnotetext{
${ }^{86}$ PLD Art. 15 para. (1)(b).

${ }^{87}$ Luxembourg and Finland. Hungary and Spain do not provide for the defense only in the pharmaceuticals sector, while France excludes it regarding products of the human body - see Report from the Commission to the European Parliament, the Council and the European Economic and Social Committee on the Application of the Council Directive on the approximation of the laws, regulations, and administrative provisions of the Member States concerning liability for defective products (85/374/EEC), COM(2018) 246 final (May 7, 2018), 4 [hereinafter Commission Report 2018].

${ }^{8}$ Rott, supra note 36, 35.

${ }^{89}$ Ebers, supra note 59, 110; Janine Wendt and Marcel Oberländer, Produkt- und Produzentenhaftung bei selbstständig veränderlichen Systemen, ZEITSCHRIFT FÜR INNOVATIONS- UNDTECHNIKRECHT [InTer] 58, 60 (2016).

${ }^{90}$ Ebers, supra note 59, 115.
} 
Concurrent causes of an accident, such as a defective collision avoidance system combined with failure of the driver to monitor adequately system performance, are very likely to create joint and several liability towards third parties.

\subsubsection{Burden of proof}

The injured person is required to prove the damage, the defect and the causal relationship between defect and damage (Art. 4).

According to the CJEU, under the principle of procedural autonomy and subject to the principles of equivalency and effectiveness, evidentiary issues are governed by the national law of each MS. The CJEU underlines the principle of effectiveness, which requires that national procedural rules do not render practically impossible or excessively difficult the exercise of rights conferred by EU law. Yet, such rules must not undermine the apportionment of the burden of proof established in the PLD. Thus, circumstantial evidence may be allowed in certain cases, to establish such relationship, and alleviate the plaintiff's burden of proof. However, this is allowed only on a case-by-case basis and provided that the burden of proof is not practically reversed. It would be a violation of the Directive's rules, if a presumption of a causal link could be automatically created when specific facts, pre-identified by the legislature or a judicial body, are proven. ${ }^{91}$

The provisions of the PLD on the burden of proof have received criticism as imposing an extreme burden of proof on claimants, especially in cases of complex products. ${ }^{92}$ The European Commission has characterised the burden of proof of the causal link between the defect and the claimant's damage as "the single most difficult stepping stone to receiving compensation". ${ }^{93}$ However, such difficulties have been mitigated mainly by the practice of courts in many MS by granting evidentiary facilitations under specific circumstances. ${ }^{94}$

The use of circumstantial evidence is important in cases of $\mathrm{AV}$, which are complex, technologically advanced products. National courts in the EU may provide evidentiary facilitations to plaintiffs, such as proof based on the balance of probabilities instead of full proof; but such facilitation is not allowed to result in changing the allocation of the evidentiary burden foreseen in the PLD.

\subsubsection{Time limits}

Concerning time bars, the PLD establishes a limitation period of three years from the day on which the plaintiff became aware, or should reasonably have become aware, of the damage,

\footnotetext{
91 See in detail CJEU case C-612/15, Criminal proceedings against Nikolay Kolev and Others, https://curia.europa.eu, paras 26 et seq.

${ }^{92}$ Noussia, supra note 51, 259.

${ }^{93}$ Commission Report 2018, supra note, 5 .

${ }^{94}$ See Commission Report 2001, supra note 77, 14-15.
} 
the defect and the identity of the producer [Art. 10(1)]. In any case, the producer's liability is extinguished upon the expiry of a period of 10 years from the date on which the producer put into circulation the actual product which caused the damage, unless the injured person has in the meantime instituted proceedings against the producer (Art. 11).

The 10-year period is mainly justified by the fact that strict liability puts a higher burden on producers than fault-based liability; therefore, the liability period is limited in order not to discourage technological innovation and to allow insurance cover. ${ }^{95}$ Nevertheless, it has been criticized as too short for some categories of products, ${ }^{96}$ to which AV could be added. In the long-run, the 10-year limitation period entails that manufacturers will not be liable for defects of older vehicle models.

\subsubsection{Product liability insurance}

The European Commission has examined the possibility of introducing mandatory productliability insurance, but has not found any compelling reasons to do so, since such insurance is widely available in the market and no practical problems have been reported. ${ }^{97}$ However, in some MS, e.g. France, there is such duty. Moreover, it has been submitted that a duty to obtain product liability insurance should be imposed, to ensure victim compensation in the event of the insolvency of the producer and in view of the wide availability and use of such insurance in the insurance market. ${ }^{98}$

\subsection{Recent legislative developments}

According to the latest evaluation of the PLD conducted by the European Commission (EC), the PLD continues to be a useful tool and to serve its purpose. ${ }^{99}$ Nevertheless, the EC believes that clarifications are needed regarding certain concepts, such as 'product', 'producer', 'defect', 'damage' and the burden of proof. ${ }^{100}$

At the same time, following a series of generic policy documents of EU institutions on new technologies and artificial intelligence, ${ }^{101}$ the EC drafted a Staff Working Document (SWD) on liability for emerging digital technologies, to identify legal challenges that new technologies, including autonomous vehicles, pose to the existing European and EU Member

\footnotetext{
95 Id., at 20.

96 Rott, supra note $36,46$.

${ }^{97}$ Commission Report 2001, supra note 77, 21.

${ }^{98}$ Rott, supra note $36,47-48$.

${ }^{99}$ Commission Report 2018, supra note 87, 6.

${ }^{100} I d$., at 8-9.

${ }^{101}$ See Communication from the Commission to the European Parliament, the Council, the European Economic and Social Committee and the Committee of the Regions on the Mid-Term Review on the implementation of the Digital Single Market Strategy A Connected Digital Single Market for All, COM(2017) 228 final (May 5, 2017); European Parliament resolution of 16 February 2017 with recommendations to the Commission on Civil Law Rules on Robotics (2015/2103(INL), 2018 O.J. (C 252) 239.
} 
States legislation due to their novel technical and operational characteristics. ${ }^{102}$ The EC is going to set up an Expert Group on 'Liability and new Technologies', which will work in two formations: the 'Product Liability Directive' formation and the 'New Technologies' formation. The 'first formation, will discuss issues mainly on an update of the concepts of 'producer', 'product' and 'defect', the development risk defense and the $500 €$ damage threshold, while the latter will analyze other relevant issues, such as the overall liability regimes. ${ }^{103}$

\subsection{Product safety}

The rules on product safety may also play a role in the potential liability of the manufacturer. These rules lay down safety requirements, combined with technical standards and procedures, which aim at ensuring the safety of the consumer products sold in the EU. Although these rules do not regulate directly product liability, they are often seen as rules protecting consumer interests and may create actionable rights against manufacturers, according to national tort rules on breach of statutory duty.

\subsubsection{General Product Safety Directive}

The general rules on product safety are contained in Directive 2001/95/EC, known as General Product Safety Directive (GPSD). ${ }^{104}$ The GPSD applies complementarily to sector-specific EU legislation [Art. 1(2)].

A product is 'safe' when, under normal or reasonably foreseeable conditions of use including duration and, where applicable, putting into service, installation and maintenance requirements, does not present any risk or only the minimum risks compatible with the product's use, considered to be acceptable and consistent with a high level of protection for the safety and health of persons, taking all circumstances into account [Art. 2(b)]. Furthermore, a product is deemed safe, when, in the absence of specific EU-law provisions, it conforms to the specific rules of national law of the Member State in whose territory the product is marketed [Art. 3(2)], as well as when it conforms to voluntary national standards transposing European standards [Art. 3(3)].

The GPSD obliges manufacturers to warn users on possible risks related to the use of the product, throughout the normal or reasonably foreseeable period of its use, where such risks are not immediately obvious without adequate warnings [Art. 5(1)]. Distributors are also required to act with due care in this regard and, if necessary, withdraw the product from the market or recall it from consumers [Art.5(2)]. Where the producers or distributors know or ought to know possible risks related to the use of the product, they must inform the competent authorities of the MS and cooperate with them on the appropriate actions [Art. 5(3)-(4)].

\footnotetext{
${ }^{102}$ European Commission Staff Working Document on liability for emerging digital technologies, SWD (2018) 137 final (Apr. 25, 2018).

${ }^{103} \mathrm{Id}$, at 17-21.

${ }^{104}$ Directive 2001/95/EC of the European Parliament and of the Council of 3 December 2001 on general product safety, Official Journal L 11, 15 Jan. 2002, pp. 4-17.
} 


\subsubsection{Safety of motor vehicles and components}

Directive 2007/46/EC ${ }^{105}$ establishes EU-wide harmonized rules for type approval of motor vehicles and their components. These rules regard the administrative procedure and technical requirements, the latter being annexed to the Directive. ${ }^{106}$ Furthermore, Regulation (EC) No $78 / 2009^{107}$ lays down special type-approval rules of motor vehicles regarding pedestrians and other vulnerable road users, such as cyclists.

It is noteworthy that type approval of a vehicle does not release the manufacturer from its liability, because they are the minimum technical requirements and higher safety standard are usually expected in particular cases. ${ }^{108}$

\subsection{Motor Insurance}

Directive 2009/103/EC (Motor Insurance Directive - MID) ${ }^{109}$ consolidates and codifies five pre-existing Directives on motor insurance, the first of which dates back to $1972 .{ }^{110}$ However, their content remains largely the same, which means that the case law of the (former) European Court of Justice on the interpretation of their provisions remains valid. ${ }^{111}$

\subsubsection{Objective}

The MID has a dual objective: on the one hand to ensure the free movement of vehicles normally based on EU territory and of persons travelling in those vehicles; on the other hand, to guarantee that the victims of accidents caused by those vehicles receive comparable treatment irrespective of where in the European Union the accident occurred. ${ }^{112}$ It is a minimum harmonization Directive, which means that MS may lay down measures more protective for victims than these provided for by the MID. ${ }^{113}$

It should be underlined that the MID does not seek to harmonize national laws on traffic liability. EU MS remain free to determine conditions and type of such liability (strict or fault

\footnotetext{
105 Directive 2007/46/EC of the European Parliament and of the Council of 5 September 2007 establishing a framework for the approval of motor vehicles and their trailers, and of systems, components and separate technical units intended for such vehicles, 2007 O.J. (L 263) 1.

106 E.g. Electronic Stability Control (ESC), daylight running lights, seat belt requirements, maximum $\mathrm{CO}_{2}$ emissions allowed etc.

${ }^{107}$ Regulation (EC) No 78/2009 of the European Parliament and of the Council of 14 January 2009 on the typeapproval of motor vehicles with regard to the protection of pedestrians and other vulnerable road users, amending Directive 2007/46/EC and repealing Directives 2003/102/EC and 2005/66/EC, 2009 O.J. (L 35) 1.

108 See e.g. Bundesgerichtshof [BGH] [Federal Supreme Court] Oct. 7, 1986 (Verzinkungsspray), VERSICHERUNGSRECHT, 102 (para. 15), 1987 (Ger.).

${ }^{109}$ Directive 2009/103/EC of the European Parliament and of the Council of 16 September 2009 relating to insurance against civil liability in respect of the use of motor vehicles, and the enforcement of the obligation to insure against such liability, 2009 O.J. (L 263), 11 [hereinafter MID].

110 See MID recital (1).

${ }^{111}$ CJEU case C-334/16, José Luís Núñez Torreiro v AIG Europe Limited, Sucursal en España and Unión Española de Entidades Aseguradoras y Reaseguradoras, https://curia.europa.eu, para. 25.

${ }^{112}$ CJEU case C-162/13 Damijan Vnuk v Zavarovalnica Triglav d.d., https://curia.europa.eu, para. 50.

${ }^{113}$ Art. 28 para. 1 MID.
} 
based). ${ }^{114}$ However, the CJEU has underlined that MS must exercise their powers in compliance with EU law, whose aim, in this instance, is to ensure that compulsory motor vehicle insurance allows all passengers who are victims of an accident caused by a motor vehicle to be compensated for the injury or loss they have suffered. Therefore, the national provisions governing compensation for road accidents cannot deprive those provisions of their effectiveness. Such would be the case specifically where, solely on the basis of the passengers' contributory negligence, national rules either denied them the right to be compensated by the compulsory motor vehicle insurance or limited such a right in a disproportionate manner. It is only in exceptional circumstances that the amount of the victim's compensation may be limited based on an assessment of their particular circumstances. ${ }^{115}$

\subsubsection{Scope}

The MID lays down compulsory insurance for third-party liability in respect of the use of vehicles normally based in the territory of EU MS. The insurance obligation covers both personal injuries and property damage (Art. 3 MID). Nevertheless, the MID does not regulate other types of insurance, such as physical injury of the driver, material damage to the vehicle, vehicle theft, etc. ${ }^{116}$

'Vehicle' under the Directive means any motor vehicle intended for travel on land and propelled by mechanical power, but not running on rails, and any trailer, whether or not coupled (Art. 1(1) MID). The CJEU interprets this definition widely and observes that such definition is unconnected with the actual use of the vehicle in question. ${ }^{117}$

The concept of 'use of vehicles' is not limited to road use, but it also covers any use of a vehicle that is consistent with its normal function, e.g. the manoeuvre of a tractor in the courtyard of a farm in order to bring the trailer attached to that tractor into a barn, ${ }^{118}$ a passenger opening the door of the vehicle while parked and damaging the vehicle parked next to it, ${ }^{119}$ a fire in a parked vehicle originated in its electrical circuit that causes damage to the building where it is parked. ${ }^{120}$ Thus, the MID covers any use of a vehicle as a means of transport. ${ }^{121}$ In addition, the scope of the concept of 'use of vehicles' does not depend on the characteristics of the terrain on which the motor vehicle is used, e.g. driving on public roads - it covers any use of a vehicle that is consistent with the normal function of that vehicle. ${ }^{122}$ As a result, the CJEU has found

\footnotetext{
${ }^{114}$ ECJ case C-356/05 Elaine Farrell v Alan Whitty, Minister for the Environment, Ireland, Attorney General and Motor Insurers Bureau of Ireland, 2007 E.C.R. I-03067, paras 32-33.

115 See ECJ case C-537/03, Katja Candolin, Jari-Antero Viljaniemi and Veli-Matti Paananen v Vahinkovakuutusosakeyhtiö Pohjola and Jarno Ruokoranta, 2005 E.C.R. I-05745, paras 27-30.

${ }^{116}$ European Commission, Motor Insurance Directive, https://ec.europa.eu/info/business-economyeuro/banking-and-finance/insurance-and-pensions/motor-insurance en (last visited July 31, 2019).

117 CJEU case C-162/13, supra note 112, para. 38.

${ }^{118} I d$., para. 59.

${ }^{119}$ CJEU case C-648/17, BTA Baltic Insurance Company AS v Baltijas Apdrošināšanas Nams AS, https://curia.europa.eu , para. 48.

${ }^{120}$ CJEU case C-100/18, Línea Directa Aseguradora SA v Segurcaixa Sociedad Anónima de Seguros y Reaseguros, https://curia.europa.eu, para. 48.

${ }^{121}$ CJEU case C-514/16, Isabel Maria Pinheiro Vieira Rodrigues de Andrade and Fausto da Silva Rodrigues de Andrade v José Manuel Proença Salvador and Others, https://curia.europa.eu, para. 38

${ }^{122} I d$., paras 34-36.
} 
that the MID applies also to accidents of military vehicles in a military exercise area, access to which was prohibited for all non-military vehicles and in a part of that area which was not suitable for the use of wheeled vehicles. ${ }^{123}$ Moreover, the Directive covers also a vehicle parked on private land, solely by the choice of the owner, who no longer intends to drive the vehicle. ${ }^{124}$

Art. 1(4)(a) defines the term 'territory', which means the territory of the State of which the vehicle bears a registration plate, irrespective of whether the plate is permanent or temporary. There are special rules on the notion of 'territory' in cases where no registration is required for a particular vehicle or where the vehicle does not bear any (valid) registration plate. ${ }^{125}$

Art. 5 MID allows Member States (MS) to allow certain categories of persons and vehicles to be exempted from the obligation of compulsory insurance. MS have used this provision for exempting mainly vehicles owned by State and regional authorities or agencies, as well as slowly-moving vehicles used in agriculture under certain conditions, motorized wheelchairs, motorized bicycles under certain conditions, etc. ${ }^{126}$ Nevertheless, in such cases MS have to ensure that accident victims are properly compensated. ${ }^{127}$

\subsubsection{Minimum insurance limits}

Art. 9(1) MID establishes also minimum insurance limits. Such limits are reviewed by the Commission every five years after 11 June 2005, in line with the European Index of Consumer Prices, so that the minimum amount of cover is not eroded over time. ${ }^{128}$ They were last time reviewed in May 2016 and are currently as follows: (a) in the case of personal injury, a minimum amount of cover of $€ 1220000$ per victim or $€ 6070000$ per claim, whatever the number of victims; (b) in the case of damage to property, $€ 1220000$ per claim, whatever the number of victims. ${ }^{129}$

The limits for personal injury have been calculated so as to compensate fully and fairly all victims who have suffered very serious injuries, while taking into account the low frequency of accidents involving several victims and the small number of accidents in which several victims suffer very serious injuries in the course of one and the same event. ${ }^{130}$

\footnotetext{
${ }^{123}$ CJEU case C-334/16, supra note 111, para. 34.

${ }^{124}$ CJEU case C-80/17, Fundo de Garantia Automóvel v Alina Antónia Destapado Pão Mole Juliana and Cristiana Micaela Caetano Juliana, para. 52. https://curia.europa.eu.

125 See MID Art. para. 1(4)(b)-(d).

${ }^{126}$ See the comprehensive list of the exemptions per MS at https://ec.europa.eu/info/business-economyeuro/banking-and-finance/insurance-and-pensions/motor-insurance en\#documents (last visited on 9 July 2018).

${ }^{127}$ MID Recital (10).

128 MID Recital (13).

${ }^{129}$ See Communication from the Commission to the European Parliament and the Council, The adaptation in line with inflation of minimum amounts of cover laid down in Directive 2009/103/EC relating to insurance against civil liability in respect of the use of motor vehicles, and the enforcement of the obligation to insure against such liability, COM (2016) 246 final (May 10, 2016).

${ }^{130}$ MID Recital (12).
} 


\subsubsection{Persons covered}

The insurance covers also liability for personal injuries to all passengers, other than the driver, arising out of the use of a vehicle [Art. 12(1) MID]. The fact that a passenger may be the owner of the vehicle is irrelevant. ${ }^{131}$

Furthermore, it includes personal injuries and damage to property suffered by pedestrians, cyclists and other non-motorized users of the roads who are entitled to compensation in accordance with national civil law, yet without prejudice either to civil liability or to the quantum of damages [Art. 12(3) MID]. Civil liability and damages are governed by the national law of the MS and the MID does not seek to harmonize national laws on traffic liability. ${ }^{132}$

According to Art. 13 MID, national statutory provisions and contractual clauses excluding liability of the insurer towards third parties are void, if they exclude the insurer's liability for use or driving of vehicles by:

(a) persons who do not have express or implied authorization to do so, unless the victims entered voluntarily into a vehicle, which they know it is stolen. However, in such cases MS may provide that the insurer is not liable, it the victims can obtain compensation for the damage suffered from a social security body.

(b) persons who do not hold a license to drive the vehicle concerned;

(c) persons who are in breach of the statutory technical requirements concerning the condition and safety of the vehicle concerned.

Exclusions from liability coverage are void also in respect of claims by passengers, who knew or should have known that the driver was under the influence of alcohol or of any other intoxicating agent at the time of an accident [Art. 3(3) MID]. According to recital (23) of the MID preamble, the passenger is not usually in a position to assess properly the level of intoxication of the driver, whereas the objective of discouraging persons from driving while under the influence of intoxicating agents is not achieved by reducing the insurance cover for passengers who are victims of motor vehicle accidents. The effect of prohibiting all these exclusions is that victims may claim compensation from the insurer, who, after providing compensation, may take redress against the driver. ${ }^{133}$ Cover of such passengers under the vehicle's compulsory motor insurance does not prejudge any liability they might incur pursuant to the applicable national legislation, nor the level of any award of damages in a specific accident. $^{134}$

\subsubsection{Direct right of action, premium and excess}

\footnotetext{
${ }^{131}$ ECJ case C-537/03 (supra note 115), paras 32-35.

${ }^{132}$ See ECJ case C-356/05, supra note 114, paras 32-33.

133 See ECJ case C-129/94 Criminal proceedings against Rafael Ruiz Bernáldez, 1996 E.C.R. I-1829, para. 24.

${ }^{134}$ MID Recital (23), in fine.
} 
Art. $18 \mathrm{MID}$ is important from a procedural perspective as it enables claimants to bring a direct action against the insurer covering the person liable. The provision aims at facilitating an efficient and speedy settlement of claims and avoiding costly legal proceedings. ${ }^{135}$

Art. 14 clarifies issues about the insurance premium. A single premium should be demanded for the compulsory insurance coverage foreseen in the MID, which should cover the entire territory of the EU throughout the duration of the contract. In case that the vehicle causes an accident in an EU MS other that the MS in which it is registered and these MS provide for different insurance limits, then the insurance should cover whichever limit is higher.

Art. 17 MID prohibits insurers from requiring third parties to bear any excess. The objective of this provision is to ensure a high-level protection of victims.

\subsubsection{Other provisions}

Art. 5 MID prohibits MS for carrying out regular border checks on insurance cover of vehicles coming out from other MS, but allows them to do so on a non-systematic basis.

Furthermore, the MID provides for the creation of guarantee funds, to provide compensation for damage caused by an unidentified vehicle or a vehicle for which the insurance obligations have not been satisfied (Arts 10-11 and 25). It also introduces a mechanism to compensate local victims of accidents caused by vehicles from another EU MS, while requiring that claims about an accident in an EU country other than the victim's country of residence be settled quickly (Arts 19-26). Moreover, policyholders are entitled to request at any time a statement relating to the third-party liability claims involving the vehicle or vehicles covered by the insurance contract at least during the preceding five years of the contractual relationship, or to the absence of such claims (Art.16).

\subsubsection{Applicability to AV}

The broad scope of the MID, as interpreted by recent judgments of the CJEU, ${ }^{136}$ includes all vehicles used as means of transport, irrespective of their equipment and automation level. The definition of 'vehicle' under the MID is technology neutral. ${ }^{137}$ Hence, all provisions of the MID mentioned above apply also in respect of AV.

It is noteworthy that the MID applies to vehicles with a 'driver' and that passengers are considered third parties. The arising question is whether a single person on board an automated vehicle could qualify as a passenger. We submit that as long as the vehicle in question is not fully automated, i.e. falls under Level 5 SCE, the human responsible for control of the vehicle even in parts of the travel should always be considered to be the 'driver', even if in some parts

\footnotetext{
${ }^{135}$ MID Recital (30).

${ }^{136}$ See supra notes 117 - 123.

${ }^{137}$ See European Commission, Inception Impact Assessment - Adaptation of the scope of Directive 2009/103/EC on motor insurance, 8 June 2016, at 4, $\underline{\text { http://ec.europa.eu/smart- }}$ regulation/roadmaps/docs/2016 fisma 030 motor insurance en.pdf (last visited July 31, 2019).
} 
of the journey the vehicle operates in automated mode. Despite the operation in automated mode, the 'driver' is expected to take over control of the vehicle upon appropriate notification from the vehicle system or on his/her own initiative. Thus, as long as the person on board the vehicle may resume control at will, that person is a 'driver' and not a 'passenger'.

Especially important in practice will be the right of third parties to turn directly against the insurer of the vehicle. In the revision process of the MID, ${ }^{138}$ some stakeholders reiterated that this should not change: third parties should continue to receive compensation from the insurer that issued the motor insurance policy, who would then take recourse against the party responsible for the accident. ${ }^{139}$

\subsubsection{Revision of the MID and AV}

In 2016 the European Commission announced an evaluation of the MID, to identify possible areas in need of reform, including cases of technological developments such as automated vehicles. The conclusion was that the MID was fit for purpose, but certain amendments are deemed necessary. ${ }^{140}$ However, these did not include AV.

As a result, the Commission laid down a proposal for a new Directive, which is intended to amend specific areas of the MID. ${ }^{141}$ The proposed amendments include engaging the guarantee funds, which compensate victims in cases of uninsured vehicles, in compensating victims in the event of insolvency of the insurer; measures to reduce uninsured driving; harmonization of the content and format of the claims statements that insurers issue at the request of policyholders; further harmonization of the minimum insurance limits.

Moreover, the Commission proposes to clarify the MID's scope in light of recent case law of the CJEU. The Commission's proposal is to include a definition of the 'use of a vehicle' as any use of the vehicle, intended normally to serve as a means of transport, which is consistent with the normal function of that vehicle, irrespective of the vehicle's characteristics and irrespective of the terrain on which the motor vehicle is used and of whether it is stationary or in motion.

\footnotetext{
138 See infra, under 2.5.9.

139 See comments of the German Insurance Association, dated 18 August 2017, available at https://ec.europa.eu/info/law/better-regulation/initiatives/ares-2017-3714481/feedback/F6707 en?p id=39849 (last visited on July 31, 2019) and the UK Association of Personal Injury Lawyers, dated 17 August 2017, available at https:/ec.europa.eu/info/law/better-regulation/initiatives/ares-20173714481/feedback/F6693_en?p_id=39849 (last visited July 31, 2019). The rest of the stakeholders who sent comments either stated in general that the MID applies to AV or did not comment at all thereon.

${ }^{140}$ European Commission, Executive Summary of the Impact Assessment Accompanying the Document Proposal for a Directive of the European Parliament and of the Council Amending Directive 2009/103/Ec of the European Parliament and of the Council of 16 September 2009 relating to insurance against civil liability in respect of the use of motor vehicles, and the enforcement of the obligation to insure against such liability, at 1 , SWD (2018) 248 final (Apr. 25, 2018).

${ }^{141}$ Proposal for a Directive of the European Parliament and of the Council amending Directive 2009/103/EC of the European Parliament and the Council of 16 September 2009 relating to insurance against civil liability in respect of the use of motor vehicles, and the enforcement of the obligation to ensure against such liability, COM (2018) 336 final (May 24, 2018).
} 
As to $\mathrm{AV}$, the evaluation process showed that the MID does not need any amendments to accommodate AV. These were found to be fully covered by the existing provisions, which are technology neutral, and no need to reform exists. ${ }^{142}$

\section{German Law}

Since 2015 the German federal government in cooperation with an interdisciplinary group of experts named the Automated Driving Round Table has been implementing a national strategy for automated and connected driving, which includes changes to the German traffic regulatory framework. ${ }^{143}$ In this regard, the German government set up in September 2016 an independent Ethics Commission, which delivered a Report on Automated and Connected Driving in June 2017. ${ }^{144}$ Moreover, the provisions of the German Road Traffic Act (StVG) on the liability of vehicle keepers and drivers were amended in March 2017, to include automated driving. To the rest, there are rules on product liability based on the transposition of the PLD, as well as on special case law on the application of general tort rules to issues of defective products.

We shall examine the new liability rules of the StVG on AV and the application of the current product-liability rules to AV, alongside with the recommendations of the Ethics Commission which provide useful guidance.

\subsection{Third-party liability of the vehicle's keeper and driver}

In German law there are special rules on third-party liability of the vehicle keeper and driver, which do not affect their potential liability under other provisions, e.g. general rules on torts. These rules can be found in Part II ( $\S 7$ - 20) of the Road Traffic Act (StVG) ${ }^{145}$. In 2017 the rules were amended to include AV. ${ }^{146}$

The keeper of the vehicle (Halter) is the person who uses the vehicle for her own account and is entitled to use the vehicle in such manner. ${ }^{147}$ The vehicle keeper is identified according to factual and economic criteria, e.g. a lessee can also be keeper, ${ }^{148}$ which means that the keeper

\footnotetext{
${ }^{142}$ European Commission MEMO/18/3732, Frequently asked questions: Commission proposal to amend the Motor Insurance Directive (May 24, 2018), http://europa.eu/rapid/press-release_MEMO-18-3732 en.htm (last visited July 31, 2019).

${ }^{143}$ BundesRegierUNG [Federal Government], Strategy FOR AUTOMATEd ANd CONNECTED Driving, Sept. 2015, 16-18, English version at https://www.bmvi.de/SharedDocs/EN/publications/strategy-for-automated-andconnected-driving.pdf? _ blob=publicationFile (last visited July 31, 2019).

${ }^{144}$ ETHICs COMmission, AutOMATED AND CONNECTED DRIVING, June 2017, https://www.bmvi.de/SharedDocs/EN/publications/report-ethics-commission.pdf? blob=publicationFile (last visited July 31, 2019) [hereinafter German Ethics Commission].

${ }^{145}$ Straßenverkehrsgesetz [StVG] [Road Traffic Act], May 3, 1909, RGBl. at 437 (Ger.), repromulgated March 5, 2003,BGBL. I at 310, 919 (Ger.).

${ }^{146}$ Achtes Gesetz zur Änderung des Straßenverkehrsgesetzes [Eighth Act to Amend the Road Traffic Act], June 16,2017, BGBL. I at 1648.

${ }^{147}$ Bundesgerichtshof [BGH] [Federal Court of Justice] May 29, 1954, NEUE JuRISTISCHE WochENSCHRIFT [NJW] 1954, 1198, para. 16 (Ger.).

${ }^{148}$ See Bundesgerichtshof [BGH] [Federal Court of Justice] July 10, 2007, NEUE JURISTISCHE WochENSCHRIFT [NJW] 2007, 3120, para. 11 (Ger.).
} 
does not necessarily coincide with the owner of the vehicle. The driver is the person who sets the car in motion under her own responsibility and steers it during the drive ${ }^{149}$.

\subsubsection{The rules for conventional vehicles}

According to $\S 7 \mathrm{StVG}$, the keeper is strictly liable for any damage or injury caused by the vehicle, unless such damage or injury is due to force majeure (höhere Gewalt) or the vehicle has been stolen. §12(1) StVG limits the keeper's liability to $€ 5 \mathrm{~m}$ per accident for personal injuries and to $€ 1 \mathrm{~m}$ per accident for property damage. In case the amount of the compensation due to more than one person is higher, each injured/damaged person receives an amount proportionally reduced $[\S 12$ (2)]. Regarding time limits, $\S 15$ StVG obliges the injured/damaged persons to notify the vehicle keeper within two months from the day they became aware of the damages and the liable person, unless the latter has obtained knowledge of the accident otherwise.

$\S 17(1)-(2)$ StVG provides for cases in which two or more vehicles are engaged in an accident. In such cases, the apportionment of liability between/among the keepers in their relation to each other depends on the circumstances of the case, especially regarding the extent of the damage caused by the respective vehicle. However, under $\$ 17(3)$ there is no liability in this regard if the accident was due to an unavoidable event, which referred neither to the quality of the vehicle properties (Beschaffenheit) nor to a failure of the vehicle equipment (Vorrichtungen). An event is 'unavoidable', when both the keeper and driver exercised every possible care. ${ }^{150}$

$\S 18$ StVG imposes liability on the vehicle's driver too, under the same conditions as the keeper with one important difference: the driver is not liable if she proves that she was not negligent. The rules on apportionment of liability between the vehicle keepers apply also to drivers.

\subsubsection{The new rules on $\mathrm{AV}$}

In May 2017 the StVG was amended to include rules on AV. The new rules regulate the permitted modes of operation, the rights and duties of the vehicle keeper and driver, liability limits, and storage of vehicle data. The amendments provide also for an evaluation of the new rules on the permitted modes of operation, as well as on the rights and duties of the vehicle keeper and driver. Such evaluation shall occur after 2019 based on scientific evidence. ${ }^{151}$

\subsubsection{Permitted operation modes}

\footnotetext{
${ }^{149}$ Bundesgerichtshof [BGH] [Federal Court of Justice] Mar. 22, 1977, VersicherungSRECHT 1977, 624, para. 9 (Ger.).

${ }^{150} \mathrm{StVG} \S 17$ para. 3, sentence 2.

${ }^{151}$ Straßenverkehrsgesetz [StVG] [Road Traffic Act] §1c.
} 
The new rules regulate vehicles that can be operated in 'highly-automated' (hochautomatisiert) or 'fully-automated' (vollautomatisiert) mode. These are vehicles equipped with systems able: (a) to exercise driving duties without the driver's participation, (b) to respect the traffic rules, (c) to be overridden and deactivated by the driver, (d) to recognise the need of switching back to manual driving mode, (e) to signal effectively such need to the driver, and (f) to warn on improper use of the vehicle. The manufacturer has to declare in the vehicle's system description that the vehicle fulfils the above-mentioned requirements [StVG §1a para. 2].

Such vehicles are permitted to operate in accordance with the manufacturer's instructions (bestimmungsgemä $\beta$ ) [StVG §1a para. 1], e.g. if the automated mode is intended for use only in highways, then its use on other streets is not permitted. ${ }^{152}$ The manufacturer must provide unambiguous information on the vehicle's equipment driver and the level of automation, so that the driver is aware of the intended uses of the vehicle. ${ }^{153}$

Moreover, the new rules provide for consideration of any binding international and European provisions on $\mathrm{AV},{ }^{154}$ such as the amended provisions of the Vienna Convention and the provisions of Art. 20 of the Directive 2007/46/EC on type approval. ${ }^{155}$

\subsubsection{Vehicle keepers and drivers}

The keepers of 'highly-automated' or 'fully-automated' vehicles are allowed to look away from the traffic and leave the wheel during vehicle operation in such modes; however, they must be alerted to take over control of the vehicle 'without delay' (unverzüglich), when the vehicle system asks them to or when it becomes obvious from the circumstances that the requirements for high-automated or fully-automated driving are not met ( $\$ 1 \mathrm{~b} \mathrm{StVG})$, e.g. when owing to bad weather the vehicle's sensors are unable to function properly. ${ }^{156}$ It is noteworthy that a technical problem or defect of the ADS does not exclude the keeper's liability, as it qualifies neither as force majeure under $§ 7(2) \mathrm{StVg}$ nor as an unavoidable event under $§ 17(3)$ StVG. ${ }^{157}$

'Driver' of the vehicle is also the person that engages its high-automated or fully-automated mode, even if she has hands off the wheel [§1a(4) StVG]. This provision clarifies that an automated vehicle may not be operated without a driver. ${ }^{158}$

If the driver of an AV has not been negligent, she will be exculpated in cases of technical defects, both according to the special rules of the StVG and the general rules on torts. ${ }^{159}$ Such

\footnotetext{
${ }^{152}$ See Regierungsentwurf [Cabinet Draft ], Bundesrat Drucksachen [BR] 69/17, 7 (Ger.).

${ }^{153} I d ., 14$.

${ }^{154}$ Straßenverkehrsgesetz [StVG] [Road Traffic Act] $§ 1$ para. 3 (Ger.).

155 See supra notes 22 and 105 respectively.

${ }^{156}$ Regierungsentwurf [Cabinet Draft ], supra note 152, 6.

157 Tobias Hammel, Haftung Und Versicherung Bei PERsonenKraftwagen mit

FAHRERASSISTENTSYSTEMEN 90-91 (2016); Petra Buck-Heeb \& Andreas Dieckman, Zivilrechtliche Haftung von Fahrer und Halter bei (Teil-) Autonomem Fahren, in AUTONOMES FAHREN 59, 77-78 (Bernd H. Oppermann \& Jutta Stender-Vorwachs eds., 2017); Renate Schaub, Interaktion von Mensch und Maschine, JURISTENZEITUNG [JZ] 342, 343 (2017).

158 Regierungsentwurf [Cabinet Draft], supra note 152, 14.

${ }^{159} I d$., at 17 .
} 
would be the case, before the trip, if the driver has ensured that the condition of the vehicle is good and its systems are properly configured and function without any problems. ${ }^{160}$ During the trip, the driver should be able to trust the ADS, but she should monitor its function to ensure that it is operating properly, by regularly checking the system and the road. ${ }^{161}$ The driver would not be liable if she can prove that the accident was due to a technical defect of the ADS and that she did not breach her monitoring duties in this regard. ${ }^{162}$

The limits of the keeper's liability for personal injury and property damage are doubled, and are set to $€ 10 \mathrm{~m}$ and $€ 2 \mathrm{~m}$ respectively [ $\$ 12(1)$ as amended]. These limits aim at the protection of accident victims and have been set at these amounts, because there is no experience yet with claims arising from the operation of AV. ${ }^{163}$

Consequently, the new rules channel liability to the vehicle keeper, who remains strictly liable and can afterwards clarify the exact apportionment with the manufacturer. ${ }^{164}$

\subsubsection{Storage of vehicle data}

To clarify who was controlling the vehicle at the time of the accident (car system or driver), a new $\S 63 \mathrm{a}$ StVG provides that AV should store satellite data on positioning and timing each time the operation mode is shifted from automated to manual and vice versa. Furthermore, such data should be stored, also when the vehicle system calls the driver to take control or when a technical malfunction occurs in the vehicle system. The stored data must be communicated to the competent authorities upon demand and to the extent necessary for the purpose of their investigation. Moreover, the data must be handed over, upon demand, to third parties involved in an accident with an automated vehicle, to the extent necessary to enable the exercise of their legal rights. Data should be stored for a period of six months, unless the vehicle has been involved in an accident, in which case the storage period is three years.

\subsection{Product liability}

Apart from Directive 85/374/EEC, which has been transposed into German law through the Product Liability Act (Produkthaftungsgesetz), ${ }^{165}$ the rules of product liability in German law

\footnotetext{
${ }^{160}$ Buck-Heeb \& Dieckman, supra note 157, 71; Ebers, supra note 59, 115.

${ }^{161}$ Buck-Heeb \& Dieckman, supra note 157, 73.

162 Id., 74.

${ }^{163}$ Regierungsentwurf [Cabinet Draft ], supra note 152, 8.

${ }^{164} \mathrm{Id}$., 8.

${ }^{165}$ It is noteworthy that $\S 10$ para. 1 of the German Product Liability Act (Produkthaftungsgesetz) caps the liability of producer to $€ 85$ million for personal injuries, using the possibility provided by Art. 16 para. 1 PLD.
} 
have been developed mainly through special interpretation of the general rules of the German Civil Code (BGB) $)^{166}$ on torts ${ }^{167}$ by the Federal Supreme Court (BGH).

The most important provision in this regard starting point is $\S 823$ BGB (1) which provides

A person who, intentionally or negligently, unlawfully injures the life, body, health, freedom, property or another right of another person is liable to make compensation to the other party for the damage arising from this.

\subsubsection{Tortious liability of the manufacturer}

$\S 823(1)$ BGB is the German equivalent of the common-law rules on the tort of negligence.

In product liability cases, the core of the manufacturer's unlawful behavior is the manufacturer's duty of care to the users of the product (Verkehrssicherungspflicht), the negligent (or intentional) breach of which may result in its duty to compensate victims. ${ }^{168}$

The duty of care consists of preventing risks arising from the use of the product, when such prevention is considered necessary according to public perception (Verkehrsauffassung) and expectations, which are examined case by case. ${ }^{169}$

The notion of product includes software. ${ }^{170}$

\subsubsection{Liable persons}

Liable is the person that manufactures and places into circulation a product. The end manufacturer is responsible for the safe construction of the end product. ${ }^{171}$ They may also be liable for components manufactured by a supplier. ${ }^{172}$ In this regard, sample tests may suffice, as long as the components do not influence significantly the safety of the end product. ${ }^{173}$

\footnotetext{
${ }^{166}$ A translation of the text of the German Civil Code into English can be found at https://www.gesetze-iminternet.de/englisch bgb/englisch bgb.html\#p3489 (last visited on 10 Nov. 2017).

${ }^{167}$ See in this regard BASIL S. MARKESINIS \& HANNES UNBERATH, THE GERMAN LAW OF TORTS: A COMPARATIVE TREATISE 97 et seq. and 555 et seq. (4th ed. 2002).

${ }^{168}$ Bundesgerichtshof [BGH] [Federal Court of Justice] Nov. 26, 1968 (Hühnerpest), 51 Entscheidungen des Budesgerichtshofes in Zivisachen [BGHZ] 91.

169 Bundesgerichtshof [BGH] [Federal Court of Justice] Oct. 17, 1989 (Pferdebox), VERSICHERUNGSRECHT [VersR] 1307 (para. 9), 1989; Bundesgerichtshof [BGH] [Federal Court of Justice] Oct. 7, 1986 (Verzinkungsspray), VERSICHERUNGSRECHT [VersR] 102 (para. 14), 1987;.

170 See in detail Matthias Lehmann, Produkt- und Produzentenhaftung für Software, NEUE JURISTISCHE WOCHENSCHRIFT [NJW] 1721, 1722-1723 (1992).

${ }^{171}$ Bundesgerichtshof [BGH] [Federal Court of Justice] June 7, 1988 (Sprudelflasche), NEUE JURISTISCHE WOCHENSCHRIFT [NJW] 2611 (para. 8), 1988.

172 Bundesgerichtshof [BGH] [Federal Court of Justice] June 3, 1975 (Spannkupplung), NeUE JURISTISCHE WOCHENSCHRIFT [NJW] 1827 (para. 22), 1975; Bundesgerichtshof [BGH] [Federal Court of Justice] July 5, 1960 (Kondensomat), VERSICHERUNGSRECHT [VersR] 855 (para. 19), 1960.

${ }^{173}$ Bundesgerichtshof [BGH] [Federal Court of Justice], July 5, 1960 (Kondensomat), VERSICHERUNGSRECHT [VersR] 855 (para. 19), 1960.
} 
Component part manufacturers bear separate liability for damage due to defects of the components, ${ }^{174}$ as well as for providing to the manufacturer of the end product inadequate information on the use and the specifications of the component. ${ }^{175}$ In the context of $\mathrm{AV}$, component manufacturers may be responsible for the software of the AV or parts thereof and the sensors of the vehicle.

The distributor of the manufacturer can also be held liable under special circumstances, e.g. when the distributor is a domestic affiliate of a foreign manufacturer and has undertaken to provide information to the parent company. ${ }^{176}$ Such instances may not be unusual in the case of AV, the manufacturers of which will have affiliates entrusted with collecting data on the use of the product in the local market.

The assemblers of the end product may be liable like manufacturers, because the assembly procedure results in a new product and is deemed a production process. ${ }^{177}$ Nevertheless, it is required that the defect could be detected during the assembly, which does not entail a duty of assemblers to examine thoroughly all the products delivered to them. ${ }^{178}$

\subsubsection{Categories of defect}

The manufacturer's duty of care and the corresponding product defects can be categorized into design defects (Konstruktionsfehler), manufacturing defects (Fabrikationsfehler), failure to warn (Instruktionsfehler) and product monitoring defects (Produktbeobachtungsfehler).

\subsection{Design defects}

A design defect exists when the product's design does not correspond to the safety required under the technical standards and knowledge (state of the art) at the time it was released to the market. ${ }^{179}$ Such defect means that the product as to its conception does not offer the required safety. ${ }^{180}$ Compliance with the existing technical standards, e.g. in the form of certification,

\footnotetext{
174 Bundesgerichtshof [BGH] [Federal Court of Justice] Dec. 9, 1986 (Honda- Lenkerverkleidung), NEUE JURISTISCHE WOCHENSCHRIFT [NJW] 1009 (para. 19), 1987; Bundesgerichtshof [BGH] [Federal Court of Justice] Oct. 17, 1967 (Schubstrebe), NEUE JURISTISCHE WOCHENSCHRIFT [NJW] 247 (para. 28), 1968;

175 Bundesgerichtshof [BGH] [Federal Court of Justice] May 14, 1996 (Grim'sches Leitrad), Neue Juristische Wochenschrift [NJW] 2224 (paras. 16-17), 1996.

${ }^{176}$ Bundesgerichtshof [BGH] [Federal Court of Justice] Dec. 9, 1986 (Honda- Lenkerverkleidung), NEUE JURISTISCHE WOCHENSCHRIFT [NJW] 1009 (para. 14).

177 Bundesgerichtshof [BGH] [Federal Court of Justice] Mar. 24, 1992 (Nockenwellensteuerrad), VERSICHERUNGSRECHT [VersR] 758 (para. 10), 1992.

178 .Bundesgerichtshof [BGH] [Federal Court of Justice] June 14, 1977 (Autokran), VERSICHERUNGSRECHT [VersR], 839 (para. 13), 1977; Bundesgerichtshof [BGH] [Federal Court of Justice] June 3, 1975 (Spannkupplung), NEUE JURISTISCHE WOCHENSCHRIFT [NJW] 1827 (para. 23), 1975.

${ }^{179}$ Bundesgerichtshof [BGH] [Federal Court of Justice] Oct. 3, 1984 (Garantieversicherung), JURISTENZEITUNG [JZ] 99, para. 12, 1985; Bundesgerichtshof [BGH] [Federal Court of Justice], May 17, 1957 (Gelenkwellenschutz), VERSICHERUNGRECHT [VersR] 584, paras 10-11, 1957.

${ }^{180}$ Bundesgerichtshof [BGH] [Federal Court of Justice] June 16, 2009 (Airbag), Docket No VI ZR 107/08, NEUE JURISTISCHE WOCHENSCHRIFT [NJW] 2952, para.15, 2009.
} 
does not preclude negligence, as such standards lay down only the minimum requirements. ${ }^{181}$ Practicability of additional safety measures in terms of a cost-benefit analysis is an additional factor to be considered. At the same time, manufacturers do not have to apply safety measures the efficiency of which has not been tested yet. ${ }^{182}$ Nonetheless, the product must provide always a minimum level of safety. ${ }^{183}$

In the context of AV, design defects could have the form of failure of the ADS to conceive and interpret its environment, in other words failure in situational awareness, ${ }^{184}$ failure to cooperate and communicate with other road users and with the human driver, ${ }^{185}$ navigation defects (route planning and localization) ${ }^{186}$ and failure to provide functional safety. The latter consists of failure to ensure appropriate security and integrity of the vehicle data, ${ }^{187}$ including on-board failure diagnosis. ${ }^{188}$ This means that back-up (redundant) systems should be in place to substitute for the system failure or at least bring the DDT safely into an end, until the human driver takes over. ${ }^{189}$ Thus, in emergency situations the ADS should automatically enter into a 'safe condition'. 190

Should the system instruct the driver to resume control of the vehicle, the manufacturer should consider human factors. ${ }^{191}$ Consequently, ADS should be designed in a way that sudden handover of control to the human driver is excluded. The ADS should be adopted to human communicative behavior ${ }^{192}$ and allow the human sufficient time to resume control; if this is impossible the ADS should retain control. ${ }^{193}$

To enable allocation of liability, it must be clearly distinguishable whether the ADS has control of the vehicle and whether the driver retains accountability with the option of overruling the system. The human-machine interface should clearly indicate at any time who is in charge (human or ADS) and whether there was a handover request by the ADS, while such information should be documented and stored. ${ }^{194}$

\footnotetext{
${ }^{181}$ Bundesgerichtshof [BGH] [Federal Court of Justice] Mar. 13, 2001, NEUE JURISTISCHE WOCHENSCHRIFT [NJW] 2019, para. 18, 2001; Bundesgerichtshof [BGH] [Federal Court of Justice] May 18, 1999 (Papierreißwolf), NEUE JURISTISCHE WOCHENSCHRIFT [NJW] 2815, para. 17, 1999.

${ }^{182}$ Bundesgerichtshof [BGH] [Federal Court of Justice] June 16, 2009 ( Airbag), NEUE JURISTISCHE WOCHENSCHRIFT [NJW] 2952 (para. 16), 2009.

${ }^{183}$ Bundesgerichtshof [BGH] [Federal Court of Justice] Nov. 21, 1989 (Korken II), NEUE JURISTISCHE WOCHENSCHRIFT [NJW] 908 (para. 24), 1990.

184 TiM HEY, DiE AUBERVERTRAGLiCHE HAFTUNG DES HERSTELLERS AUTONOMER FAHRZEUGE BEI UNFÄLLEN IM STRAßENVERKEHR 68-69 (2018).

${ }^{185} I d$., 69-71.

${ }^{186} I d ., 72$.

${ }^{187}$ Id., $72-73$.

${ }^{188}$ Hammel, supra note 157, 397.

${ }^{189}$ Id., 397; Hey, supra note 184, 73.

190 German Ethics Commission, supra note 144, at 13 (Principle No 19).

${ }^{191}$ Hey, supra note 184, 74.

192 German Ethics Commission, supra note 144, at 13 (Principle No 17).

193 Id., at 21 .

${ }^{194} I d$., at 13 (Principle No 16).
} 
The German Ethics Commission recommends that AV are designed to drive in a defensive and anticipatory manner, posing as little risk as possible to vulnerable road users. Critical situations, especially dilemma situations, in which AV have to decide between two evils, should be avoided in the first place. ${ }^{195}$ Human life enjoys priority and as such AV should be programmed to accept damage to animals or property in a conflict, if this means that personal injury can be prevented. ${ }^{196}$ Although it is prohibited to offset victims against one another, general programming to reduce the number of personal injuries may be justifiable. ${ }^{197}$ The parties involved in the creation of mobility risks should not sacrifice non-involved parties. ${ }^{198}$ Nonetheless, abstract guidance in 'dilemma situations' is not possible. The German Ethics Commission suggests that an independent public-sector agency can be entrusted with the process of the lessons learned in specific cases. ${ }^{199}$

Besides, the manufacturer has to protect third parties also from foreseeable misuses of its product, such as operation outside the ODD of the AV. ${ }^{200}$ Although $\S 1$ a StVG permits the operation of AV only within their ODD, §1a(2)(6) prescribes that the ADS should provide the driver with a warning that the ADS is being operated outside its ODD, which results in a respective duty of the manufacturer. ${ }^{201}$

\subsection{Manufacturing defects}

A manufacturing defect occurs when the design of the product is safe, but an error occurs at the production procedure, caused by the manufacturer's failure to organize the production procedure appropriately. ${ }^{202}$ A special category of manufacturing defects are the 'outliers' (Ausreißer), which are defects that cannot be avoided despite all necessary precautions and, therefore, entail no liability. ${ }^{203}$

As to $\mathrm{AV}$, manufacturers need to have in place appropriate quality-management procedures to ensure that the appropriate safety of the vehicle, e.g. control of the production machines, of the raw materials and the production procedures, testing of the vehicle sensors and software etc. ${ }^{204}$ However, the self-learning abilities of ADS entail that manufacturers need to have in place more rigorous testing procedures. ${ }^{205}$

\footnotetext{
${ }^{195} I d$., at 10 (Principle No 3).

${ }^{196} I d$., at 11 (Principle No 7).

${ }^{197} I d$., at 11 (Principle No 9).

${ }^{198} I d$. , at 11 (Principle No 9).

${ }^{199} I d$., at 11 (Principle No 8).

${ }^{200}$ Hey, supra note $184,62$.

${ }^{201} I d ., 63$.

${ }^{202} I d ., 79$.

${ }^{203}$ Bundesgerichtshof [BGH] [Federal Court of Justice] Nov. 26, 1968 (Hühnerpest), 51 Entscheidungen des Budesgerichtshofes in Zivisachen [BGHZ] 9 (para. 42); Bundesgerichtshof [BGH] [Federal Court of Justice] June 3, 1975 (Spannkupplung), NEUE JURISTISCHE WOCHENSCHRIFT [NJW] 1827 (para. 26), 1975.

${ }^{204}$ Hey, supra note $184,80$.

${ }^{205}$ Id., 81.
} 


\subsection{Failure to warn}

The failure to warn deals with the omission of the manufacturer to warn sufficiently the users of its product on possible dangers from its use. ${ }^{206}$ Such duty concerns mainly products the use of which entails dangers for the users that cannot be prevented and may be unknown to the average user. ${ }^{207}$ The manufacturer should also inform the user on the risks of the product and on its correct use, in some cases also on its incorrect use. ${ }^{208}$

The manufacturer should inform the keeper/driver on the ODD of the vehicle and its limits, as $\S 1$ a StVG indicates. ${ }^{209}$ It should also inform the driver if currently the operation of the vehicle in outside the ODD and indicate that the driver should take over. ${ }^{210}$ Especially important are the instructions regarding the human-machine interface: the human driver should know how to activate and deactivate the ADS or its components, if the ADS or components are activated and function properly or not, and how she is supposed to react in each case. ${ }^{211}$ Important are also the instructions regarding maintenance: the manufacturer should inform the user on the need to keep sensors clean, explain how software updates should be installed and warn on potential risk due to inappropriate maintenance, e.g. security risks in cases of outdated software. ${ }^{212}$

The instructions should be provided at least in the form of a user manual. However, in many cases this may not suffice, because it is very usual that users read only part of the instructions. In view of the risks created for innocent third parties therefrom, it has been proposed that the manufacturer uses interactive instructions in the on-board computer. ${ }^{213}$

\subsection{Failure to monitor the product}

Failure in product monitoring concerns the manufacturer's failure to (a) observe the results of the product's use, (b) follow the development of the technical and scientific knowledge and (c) receive appropriate measures, such as repairs, replacements, issuing warnings or even changing production methods. ${ }^{214}$ The manufacturer has to monitor the interaction of its product with other products and accessories manufactured by third parties and issue adequate warnings. ${ }^{215}$ It has to actively collect information regarding technological developments and potential risks

\footnotetext{
206 Bundesgerichtshof [BGH] [Federal Court of Justice] June 16, 2009 (Airbag), 181 Entscheidungen des Bundesgerichtshofes in Zivilsachen (BGHZ), 253 (para. 23); Bundesgerichtshof [BGH] [Federal Court of Justice] July 11, 1972 (Estil), 59 Entscheidungen des Bundesgerichtshofes in Zivilsachen (BGHZ) 172, (para. 13).

207 Bundesgerichtshof [BGH] [Federal Court of Justice] June 16, 2009 (Airbag), 181 BGHZ 253, para. 23; Bundesgerichtshof [BGH] [Federal Court of Justice] May 18, 1999 (Reisswolf), VERSICHERUNGSRECHT [VersR] 890 (para. 18), 1999.

${ }^{208}$ Bundesgerichtshof [BGH] [Federal Court of Justice] June 16, 2009 (Airbag), 181 BGHZ 253, para 23.

${ }^{209}$ Hey, supra note 184, 86; Ebers, supra note 59, 111-112.

${ }^{210}$ Hey, supra note 184, 86; Ebers, supra note 59, 113;.

${ }^{211}$ Hammel, supra note 157, 407-408; Hey, supra note 184, 87-88; Ebers, supra note 59, 111.

${ }^{212}$ Hey, supra note 184 , at 89.

213 See details in Hammel, supra note 157, 413-415.

214 Bundesgerichtshof [BGH] [Federal Court of Justice] Oct. 17, 1989 (Pferdebox), NeUE JURISTISCHE WOCHENSCHRIFT [NJW] 906 (para. 27), 1990; Bundesgerichtshof [BGH] [Federal Court of Justice] Mar. 17, 1981 (Apfelschorf II), NEUE JURISTISCHE WOCHENSCHRIFT [NJW] 1606 (para. 32), 1981.

${ }^{215}$ Bundesgerichtshof [BGH] [Federal Court of Justice] Dec. 9, 1986 ( Honda-Lenkerverkleidung), NEUE JURISTISCHE WOCHENSCHRIFT [NJW] 1009 (paras. 18 et seq.), 1987.
} 
of its product. ${ }^{216}$ It is also under duty to monitor such issues regarding competitive products, because the pertinent problems may be transferable to its own. ${ }^{217}$ The more risks entails the use of a product, the higher are the requirements to the manufacturer to monitor the safety of the product according to the current level of the scientific knowledge and to react accordingly. ${ }^{218}$ Moreover, in extreme cases, especially when there is risk of injury or death, there may be a duty to recall products. ${ }^{219}$

The application of these principles to AV entails that manufacturers of AV are obliged to continuously optimize their systems, observe the already delivered ADS and improve them wherever this is technologically possible and reasonable. ${ }^{220}$ This includes monitoring the interaction of the ADS with products and software of third parties through sample tests and problem reports. $^{221}$

Furthermore, to the extent permitted by the data protection legislation ${ }^{222}$, the AV manufacturer can collect software data from its vehicle, regarding possible failures, glitches, etc. ${ }^{223}$

As soon as the manufacturer knows about potential problems and risks, it should issue warnings to the users, which could have the form of messages on the on-board computer. ${ }^{224}$ Developing and releasing software updates is also included here. ${ }^{225}$ However, a duty of the manufacturer to offer a software update and not just a warning should be accepted only in cases of serious risk of injury to third parties. ${ }^{226}$ To the extent that such updates alter the approved specifications of the vehicle, they may need to be approved by the competent authorities, which can take some time. Such unavoidable delays in releasing the software should be taken into account, when establishing potential violations of the manufacturer's monitoring duty. ${ }^{227}$

\subsubsection{Damage}

\footnotetext{
${ }^{216}$ Hey, supra note $184,91$.

${ }^{217}$ Bundesgerichtshof [BGH] [Federal Court of Justice] Oct. 17, 1989 (Pferdebox), NeUE JuRISTISCHE WOCHENSCHRIFT [NJW] 906 (para. 27), 1990.

${ }^{218}$ Bundesgerichtshof [BGH] [Federal Court of Justice] Dec. 16, 2008 (Pflegebetten), Neue Juristische Wochenschrift [NJW] 1080 (para. 10), 2009.

${ }^{219}$ Id., para. 11.

${ }^{220}$ German Ethics Commission, supra note 144, at 12 (Principle No 11).

${ }^{221}$ Hey, supra note 184, 92-93, Ebers, supra note 59, 114.

${ }^{222}$ See especially the EU General Data Protection Regulation 2016/679 in this regard - Regulation (EU) 2016/679 of the European Parliament and of the Council of 27 April 2016 on the protection of natural persons with regard to the processing of personal data and on the free movement of such data, and repealing Directive 95/46/EC, OJ L 119, 4 May 2016, pp. 1-88.

${ }^{223}$ Hey, supra note 184, 92; Ebers, supra note 59, 114.

${ }^{224}$ Hey, supra note $184,94$.

${ }^{225}$ Compare the case of Tesla, which in May 2019 issued software updates as a response to two incidents of battery fires -Sean O'Cane, Tesla pushes battery software update after recent fires, THE VERGE (May 16, 2019, 4:01 PM EDT), https://www.theverge.com/2019/5/16/18627746/tesla-fire-battery-software-update-model-s-X (last visited July 31, 2019).

${ }^{226}$ Ebers, supra note 59,115.

${ }^{227}$ Hey, supra note $184,95$.
} 
Recoverable can be any personal damage, including pain and suffering, or damage to property, other than the defective product itself. ${ }^{228}$ However, compensation for damage to the defective product itself and related loss of income are not recoverable under the law of torts. ${ }^{229}$

A thorny problem is damage caused by a component to the whole product, known as 'spreading defect' (weiterfressender Mangel). Such damage may be compensated, if the defective component can be functionally separated from the rest of the product and the damage to the rest of the product resulted from the connection with the rest of the product. ${ }^{230}$

Punitive damages are not recoverable in Germany, because they do not have compensatory character and raise serious constitutional concerns. ${ }^{231}$

In the case of AV, damage caused to the vehicle itself by defective sensors will be recoverable, as these can be easily removed and replaced. However, in case of defective ADS software the damage will be of the same kind (stoffgleich), as the software is a central part of an AV. ${ }^{232}$ Nonetheless, the situation may be different in case of mere assisted-driving systems (Level 2 automation), the software of which may be an autonomous component of the vehicle. ${ }^{233}$

\subsubsection{Burden of proof}

Claimants must prove the existence of defect, their damage and the causal link between the defect and the damage.

As to design and manufacturing defects, German courts require manufacturers to prove that there was no breach of duty of care and no negligence in the design and the production process of the product (e.g. the defect was an 'outlier' or it was not discoverable according to the state

\footnotetext{
228 See Bürgerliches Gesetzbuch [BGB] [Civil Code] §249, translation at http://www.gesetze-iminternet.de/englisch_bgb/index.html, which provides for restitutio in integrum. See details in MARKERSINIS \& UNBERATH, supra note 167, 907 et seq.

${ }^{229}$ Bundesgerichtshof [BGH] [Federal Court of Justice] Dec. 16, 2008 (Pflegebetten), NeUE JuRISTISCHE WOCHENSCHRIFT [NJW] 1080, 2009; Bundesgerichtshof [BGH] [Federal Court of Justice] Mar. 17, 1981 (Apfelschorf II), NEUE JURISTISCHE WOCHENSCHRIFT [NJW] 1606 (para. 32), 1981.

230 Bundesgerichtshof [BGH] [Federal Court of Justice] Feb. 11, 2004 (Hinterreifen), NeUE JURISTISCHE WOCHENSCHRIFT [NJW] 1032, 2004, which regarded damage to a car caused by its defective tires; Bundesgerichtshof [BGH] [Federal Court of Justice] Nov. 24, 1976 (Schwimmerschalter), 67 Entscheidungen des Bundesgerichtshofes in Zivilsachen (BGHZ) 359, which regarded damage caused to a cleaning device by a defective safety switch.

${ }^{231}$ Bundesgerichtshof [BGH] [Federal Court of Justice] June 4, 1992 (Punitive Damages), NeUE JURISTISCHE WOCHENSCHRIFT [NJW] 3096, 1992, which refused the enforcement of a judgment of a Californian court awarding punitive damages. See also Nils Jansen and Lukas Rademacher, Punitive damages in Germany, in: Punitive Damages: Common LaW and Civil Law Perspectives 75 (H. Koziol H. and V. Wilcox V. eds., 2009)

${ }^{232}$ Hey, supra note $184,39$.

${ }^{233}$ Hammel, supra note 157, 371-372.
} 
of the art at the time it was released to the market). ${ }^{234}$ They also need to prove that each employee was carefully selected and supervised. ${ }^{235}$

Regarding the failure to warn, German courts draw a distinction on the basis of the time that the warnings should have been issued. ${ }^{236}$ If they relate to the time of placing the product to the market, manufacturers have to prove that there was no breach of their duty of care and no negligence, because they have the necessary overview in the production process and the related access to information. Nevertheless, if the failure to warn is based on facts, scientific findings and discoveries subsequent to placing the product in the market, which are also accessible to the claimant, the claimant has to prove that there was a breach of duty of care; once this is proven, manufacturers have to prove lack of negligence, e.g. because the pertinent state of the scientific art and knowledge in their domain at that time did not allow the identification of the exact danger or the methods to avoid it.

As to claims for defects of AV, claimants will have to prove the causal link between the defect and the damage, which will be a very difficult task, because the accident may be due to factors outside the manufacturer's control, such as defective software updates from third parties, insufficient maintenance of the vehicle, cyber attacks etc. ${ }^{237}$ Especially as to design and manufacturing defects, claimants should prove that the defect existed at the time the vehicle was placed in the market. In view of self-learning abilities of the AV this is very difficult to prove. $^{238}$

At the same time, manufacturers of AV will have a heavy burden of proof to meet as to nonnegligent behavior because of the strict requirements as to $\mathrm{AV} .{ }^{239}$ Regarding learned behavior of ADS, they will have to prove that they could neither predict it nor avert it. ${ }^{240}$

Consequently, the current system creates serious proof difficulties for both claimants and defendants, despite the obligatory use of the Event Data Recorder under $§ 63 \mathrm{a}$ StVG. This can undermine compensation of victims ${ }^{241}$ and increase litigation cost. Therefore, it has been proposed to impose risk liability on AV manufacturers, which means that they should be liable for all damages caused by the ADS. ${ }^{242}$ However, such legislative intervention would be

\footnotetext{
${ }^{234}$ Bundesgerichtshof [BGH] [Federal Court of Justice] Nov. 24, 1976 (Schwimmerschalter), 67 Entscheidungen des Bundesgerichtshofes in Zivilsachen (BGHZ) 359 (para. 23); Bundesgerichtshof [BGH] [Federal Court of Justice] Nov. 26, 1968 (Hühnerpest), 51 Entscheidungen des Budesgerichtshofes in Zivisachen [BGHZ] 91, (paras 40-44).

${ }^{235}$ Bundesgerichtshof [BGH] [Federal Court of Justice] June 19, 1973 (Feuerwehrkörper), NEUE JURISTISCHE WOCHENSCHRIFT [NJW] 1602 (para. 18), 1973.

236 See Bundesgerichtshof [BGH] [Federal Court of Justice] Nov. 12, 1991 (Kindertee I - Milupa), 116 Entscheidungen des Bundesgerichtshofes in Zivilsachen (BGHZ) 60 (paras 38-39); Bundesgerichtshof [BGH] [Federal Court of Justice] Mar. 17, 1981 (Apfelschorf I - Derosal), 80 Entscheidungen des Bundesgerichtshofes in Zivilsachen (BGHZ) 186 (para. 33).

${ }^{237}$ Ebers, supra note 59, 117.

${ }^{238}$ Hey, supra note 184, 106; Ebers, supra note 59, 118.

${ }^{239}$ Hey, supra note $184,104$.

${ }^{240}$ Hey, supra note 184, 104; Schaub, supra note $157,344$.

${ }^{241}$ Ebers, supra note 59, 119.

${ }^{242} I d$.,120. See a detailed analysis thereon in Hey, supra note 184, 231-239, who proposes specific amendments to the StVG in this regard.
} 
possible only at the EU level in view of the full harmonization effect of the Product Liability Directive. $^{243}$

\subsection{Insurance}

Insurance issues regarding motor vehicles are regulated mainly in the Compulsory Insurance Act (PflVG) ${ }^{244}$ and in the Motor Vehicle Compulsory Insurance Order (KfzPflVV) ${ }^{245}$. To the rest, the general provisions of the Insurance Contract Act (VVG) ${ }^{246}$ apply. The applicable provisions of these pieces of legislation transpose the MID into German law. In this section, we will focus on the particularities of German law.

\subsubsection{Scope and insurance limits}

$\S 1$ PflVG lays down the duty of the keepers of automotive vehicles to have in place third-party liability insurance covering themselves, the owners and the drivers of the vehicles. §5(2) PflVG obliges insurers to conclude insurance contracts with the persons mentioned in $\S 1$. The definition of 'vehicle' is the same under the MID, thus it comprises AV. ${ }^{247}$ The interpretation of the term 'use of a vehicle' does not differ from the MID. It includes all motor vehicles, irrespective of their technical configuration and whether there are driven by a human driver; thus it includes $\mathrm{AV} .^{248}$ The prescribed minimum insurance limits are $€ 7500000$ for personal injuries, $€ 1220000$ for property damage and $€ 50000$ for pure economic loss. ${ }^{249}$

\subsubsection{Exclusions of coverage}

$\S 117(1)$ VVG provides that the insurer remains liable towards third parties, irrespective of the release from liability towards the policyholder. The only exceptions thereto are the cases foreseen in $\S 4 \mathrm{KfzPflVV}$ and $\S 103 \mathrm{VVG}$.

$\S 4 \mathrm{KfzPflVV}$ permits exclusions of coverage only in specific cases, which deal with property damage. Thus, a general exclusion of coverage for damage resulting from $\mathrm{AV}$ is not allowed. ${ }^{250}$

\footnotetext{
${ }^{243}$ Hey, supra note 184, 239-240; Ebers, supra note 59, 121.

${ }^{244}$ Pflichtversicherungsgesetz [PflVG] [Compulsory Insurance Act], Nov. 7, 1939, RGB1. I at 2223, repromulgated Apr. 5, 1965, BGB1. I at 213, as amended.

${ }^{245}$ Kraftfahrzeug-Pflichtversicherungsverordnung [KfzPflVV] [Motor Vehicle Compulsory Insurance Order], July 29, 1994, BGBl. I at 1837, as amended.

246 Versicherungsvertragsgesetz [VVG] [Insurance Contract Act], May 30, 1908, RGB1. at 191, repromulgated Nov. 23, 2007, BGBl. I, at 2631, as amended, translation at https://www.gesetze-iminternet.de/englisch_vvg/index.html (last visited July 31, 2019).

247 Jan Eichelberger, Autonomes Fahren und Privatversicherungsrecht, in AUTONOMES FAHREN 127, 130-131

(Bernd H. Oppermann \& Jutta Stender-Vorwachs eds., 2017).

${ }^{248} \mathrm{Id}$. at $131-132$.

249 Pflichtversicherungsgesetz [PflVG] [Compulsory Insurance Act]§4 para. 2 combined with the Annex thereto.

${ }^{250}$ Eichelberger (supra note 247), 134.
} 
Furthermore, $\S 103$ VVG releases the insurer from any liability, if the insured has caused intentionally the damage. In such cases, third parties will be compensated by the Guarantee Fund, according to $§ 12(1)$ PflVG. ${ }^{251}$

\subsection{Conclusion on German law de lege lata}

Current German law on AV channels liability to the vehicle keeper, who bears strict limited liability, pursuant to the newly inserted provisions of the Street Traffic Law (StVG). Liable up to the same limits can also be the vehicle's driver for negligence.

Manufacturers of AV and components may be held either strictly liable according to the Product Liability Act (ProdHG), which transposes Directive 85/374/EEC, or liable for negligence according to the general tort liability provisions ( $\$ 823 \mathrm{BGB})$ as these have been interpreted for product-liability cases. In both cases, their liability is unlimited.

Third-party liability insurance for AV is governed by the provisions of national law that incorporate the MID and does not present any significant particularities.

\section{English law}

In English law there are no special liability rules on owners, drivers and manufacturers of AV at present. Thus, such liability is governed by rules applicable to road negligence and product liability.

Nevertheless, the recently enacted Automated and Electric Vehicles Act $2018^{252}$ provides for liability of the insurers of such vehicles. At the same time the English Law Commission and the Scottish Law Commission are reviewing the current regulatory framework for AV in the UK. A consultation process is ongoing, which is scheduled to end in 2021 with the publication of the final recommendations. So far, a preliminary consultation paper on safety assurance and legal liability has been published, ${ }^{253}$ with regard to which answers have been received and analyzed. ${ }^{254}$ Another two consultation papers are being prepared: one on automated road

\footnotetext{
${ }^{251}$ Eichelberger (supra note 247), at 142.

252 c.18 (Eng.), http://www.legislation.gov.uk/ukpga/2018/18/contents/enacted/data.htm (last visited July 31, 2019).

${ }^{253}$ LAW COMMISSION AND SCOTTISH LAW COMMISSION, AUTOMATED VEHICLES - A JOINT PRELIMINARY CONSULTATION PAPER (2018), https://s3-eu-west-2.amazonaws.com/lawcom-prod-storage11 jsxou24uy7q/uploads/2018/11/6.5066 LC_AV-Consultation-Paper-5-November_061118 WEB-1.pdf, while a summary is also available at https://s3-eu-west-2.amazonaws.com/lawcom-prod-storage11jsxou24uy7q/uploads/2018/11/6.5066_LC_AV_Final-summary_061118_WEB.pdf (last visited July 31, 2019) [Hereinafter: Government Consultation]

${ }^{254}$ See the analysis of the responses at https://s3-eu-west-2.amazonaws.com/lawcom-prod-storage11 jsxou 24 uy $7 \mathrm{q} /$ uploads/2019/06/Automated-Vehicles-Analysis-of-Responses.pdf, while a summary of the analysis is available at https://s3-eu-west-2.amazonaws.com/lawcom-prod-storage11jsxou24uy7q/uploads/2019/06/Summary-of-Automated-Vehicles-Analysis-of-Responses.pdf (last visited July $31,2019)$.
} 
passenger services, expected in Fall 2019 and one in 2020, which will draw on responses to the two previous papers to formulate overarching proposal. ${ }^{255}$

We shall examine first the general rules on third-party liability and insurance, and their applicability to AV. Subsequently we will examine the new special provisions on liability of insurers of AV, alongside with the business framework of insurance of AV in the UK.

\subsection{Road negligence}

English law provides for a system of fault liability in respect of road accidents even in situations where motor vehicles cause death or injury to pedestrians or cyclists. As a result, the claimant is required to prove the driver's negligence, namely to establish that i) he was owed a duty of care; ii) that the driver breached that duty; and iii) that damage was caused as a result of the breach.

\subsubsection{Duty of care}

Whether a duty of care exists is rarely an issue of concern in road accidents and in most cases its existence is affirmed without any problem. ${ }^{256}$ The driver is required to use reasonable care to avoid causing damage to persons, vehicles or property, i.e. the care that an ordinary skilful driver would have exercised. ${ }^{257}$ The test is objective and "... independent of the idiosyncrasies of the particular person whose conduct is in question". ${ }^{258}$ As such, learner drivers are not assessed by reference to a lower level of care courtesy of their inexperience. ${ }^{259}$

\subsubsection{Breach of the duty of care}

What behaviour constitutes breach of the duty of care has been judicially shaped over the years, with courts viewing it as a predominantly fact-based exercise. ${ }^{260}$ This is particularly obvious in the treatment of The Road Traffic Act 1988, the public law instrument which sets the road traffic rules and contains predominantly criminal law sanctions. ${ }^{261}$ Failure to observe its provisions does not necessarily mean that the defendant has been negligent and conversely, compliance therewith does not necessarily absolve the defendant. ${ }^{262}$ Consequently, the mere fact that the defendant was driving in a negligent fashion does not mean that he can be regarded

\footnotetext{
${ }^{255}$ See https://www.lawcom.gov.uk/project/automated-vehicles/ (last visited July 31, 2019).

256 Peter Cane, Atiyah's Accidents, Compensation And The LaW 69 ( $8^{\text {th }}$ ed. 2013).

257 Charlesworth \& PERCY ON Negligence $§ 10-191$ (Christopher Walton et al. eds., 13 ${ }^{\text {th }}$ ed. 2017).

258 Glasgow Corporation v. Muir [1943] A.C. 448, 457 (Lord Macmillan) (HL) (appeal taken from Scot.).

${ }^{259}$ Nettleship v. Weston [1971] 2 Q.B. 691 (Eng).

${ }^{260}$ Foskett v. Mistry [1984] R.T.R. 1 (Eng).

${ }^{261}$ Charlesworth \& Percy, supra note 257, § 10-199.

${ }^{262}$ CLERK \& LindShell ON TORTS $§ 8-202$ (Michael Jones et al eds. $22^{\text {nd }}$ ed. 2017).
} 
as liable in negligence, if an accident occurs which could not have been prevented even without negligence. ${ }^{263}$

Still, the following situations of breach can be identified: “(i) failing to keep any, or proper, look out; (ii) failing to heed the presence of the other road user in time properly or at all; (iii) failing to stop, slow down properly or at all; (iv) in the circumstances driving too fast (for example given the traffic, weather, visibility and other conditions pertaining at the time); (v) failing to steer or otherwise manage the vehicle so as to avoid the collision; (vi) sudden stopping without good cause; (vii) failing to take note of obstructions on the road; (viii) parking a vehicle in such a way as to cause a dangerous situation; (ix) over-taking or other manoeuvres when unsafe to do so; (x) driving or continuing to drive where the driver knew or ought to have known that he was ill or his faculties were otherwise adversely affected, for example, by lack of sleep; (xi) driving a vehicle notwithstanding a reasonably discoverable defect affecting its control or other safe use; (xii) failing adequately or at all to have adequate regard for the safety of pedestrians or other road users...". 264

\subsubsection{Contributory negligence}

Contributory negligence is regulated by the Law Reform (Contributory Negligence) Act 1945 which requires the reduction to the damages to such extent as the court thinks just and equitable having regard to the claimant's share in the responsibility for the damage. ${ }^{265}$ The inquiry is fact sensitive, but the general attitude of English courts in cases of injuries to pedestrians is that usually the attribution of causative potency to the driver will be greater than that of the pedestrian and thus courts consistently apply a higher burden on the motorist. ${ }^{266}$ This is so as "the potential destructive disparity between the parties could be taken into account as an aspect of blameworthiness". ${ }^{267}$

This rationale was apparent in the recent case of Jackson v. Murray where a 13-year old was hit by the car driven by the defendant while attempting to cross a rural, unlit, two-way road from the rear of a minibus. ${ }^{268}$ The Supreme Court reversing the decision of the Inner House (where contributory negligence was assessed at 70\%) opted for an equal apportionment based on the driver's level of culpability: " if [the defendant] had slowed to a reasonable speed in the circumstances and had kept a proper look-out, he would have avoided her". ${ }^{269}$ Having said that, English courts do not hesitate to award a higher degree of contributory negligence in "stepping out" cases. ${ }^{270}$

\footnotetext{
${ }^{263}$ Robert Merkin \& Maggie Hemsworth, The Law Of Motor Insurance $\S 4-12$ (2 ${ }^{\text {nd }}$ ed. 2015).

${ }^{264}$ Id. $\S 4-13$.

${ }^{265}$ Law Reform (Contributory Negligence) Act 1945, c. $28, \S 1$ (U.K).

${ }^{266}$ Merkin, supra note 263, § 4-44.

${ }^{267}$ Eagle v. Chambers [2003] EWCA Civ 1107, at [15] (Lady Hale) (Eng.).

268 Jackson v. Murray [2015] UKSC 5 (appeal taken from Scot).

${ }^{269} I d$., at [40] (Lord Reed).

${ }^{270}$ See Merkin, supra note $263, \S 4-44$ with references to case law.
} 
Such an approach can be explained by the preference for a fault-liability regime: since the duty is to drive with reasonable care, a motorist will seldom be held liable for the outcome of a splitsecond decision where a number of courses of action are open to him and each has potential disadvantages. ${ }^{271}$ It is plausible that the deployment of AV operating in autonomous modes will prompt English courts to reconsider their approach to "stepping out" cases in favour of pedestrians. This might be the case as AV in Levels 4 and 5 of automation will probably come with the ability (or at least the promise) of having faster (than the average human driver) braking reaction times.

\subsubsection{Evaluation}

It has been argued that English courts have consistently imposed on the drivers a high standard to reflect the potential dangerousness of the car. ${ }^{272}$ Yet, this tendency is not to be confused with a judicially-driven attempt to elevate the standard to one of strict liability. On the contrary, the evidence suggests that English courts strive to safeguard the reasonable-care requirement by "caution[ing] against liberal use of hindsight... which elevate[s] the standard of care to a form of guarantee of safety or a counsel of perfection...". 273

It is difficult to estimate the effect that the fault principle has on the (un)successful recovery of compensation for road accidents. What seems to be beyond doubt is that the "number of successful tort claims has increased fourfold since the 1970s". ${ }^{274}$ Beyond this estimate, it is open to debate how many victims are prevented from receiving compensation because of the requirement to prove the fault of the driver with academics supporting the view that it ranges from "a significant (although perhaps relatively small) proportion" 275 to "large numbers". 276 Still, Governments over the years have retained the negligence standard, despite official proposals for the introduction of strict liability or no-fault compensation. ${ }^{277}$

It is unlikely that the current British Government will propose a change of the current liability system for non-automated vehicles for several reasons. Firstly, question marks have been raised about the economic efficiencies of no-fault compensation schemes for road users. ${ }^{278}$ Secondly, it is becoming more difficult to justify creating no-fault compensation schemes for selective groups of victims, such as road users. ${ }^{279}$ Such ambiguities are likely to be picked up by a Government that sees no major problem with the fault-liability framework. Thirdly, the Government brushed aside the proposals for an overhaul of the liability system in the recent

\footnotetext{
${ }^{271}$ Charlesworth \& Percy, supra note 257, § 10-192.

${ }^{272}$ Lunt v Khelifa [2002] EWCA Civ 801, at [20] (Latham, L.J.) (Eng.).

${ }^{273}$ Merkin, supra note 263, § 4-07.

${ }^{274}$ Cane, supra note 256, 215.

275 Id., 215.

${ }^{276}$ Ken Oliphant, Tort Law, Risk, and Technological Innovation in England, McGILL L.J. 819,832 (2014).

${ }^{277} I d$.

${ }^{278}$ Cane, supra note 256, 465-466.

${ }^{279} I d ., 486$.
} 
consultation on $\mathrm{AV} .{ }^{280}$ This attitude is not surprising, if one considers that the response of the Government to the increase of car insurance premiums in 2012 was to reform the funding of personal injury litigation rather than the liability framework. ${ }^{281}$

Instead, the Government mandated the Law Commission to undertake a three-year review of the legal framework governing the operation of $\mathrm{AV}$, including the issue of liability. ${ }^{282}$ Its selective approach in terms of liability reforms demonstrates a reluctance to upset the basic rules of allocating risk and liability in accidents caused by conventional vehicles. It is keen to provide a stricter liability regime for $\mathrm{AV}$ on the basis that manufacturers, insurers and/or owners of the vehicles are better equipped to reduce the risk of accidents and bear their costs. Yet, it is at pains to retain the status quo with respect to unconventional vehicles.

\subsection{Insurance}

\subsubsection{Compulsory insurance obligation}

The fault liability system does not stand alone. It is supported by the UK motor insurance market which is the "largest and most competitive general insurance line of business, accounting for $£ 15.6$ billion gross written premium in 2015 ". ${ }^{283}$

The framework of compulsory insurance against third party risks is found in Part VI of the Road Traffic Act 1988, ${ }^{284}$ which essentially derives from the Consolidated Motor Insurance Directive 2009/103/EC. ${ }^{285}$ The basic provision is Section 143(1)(a), which prohibits a person to use a motor vehicle on a road or other public space in Great Britain without insurance for risks caused by, or arising out of, the use of that vehicle. Such risk regard liability in respect of death of or bodily injury to third parties, including passengers, and damage to third party property. ${ }^{286}$ This provision is supplemented by Section 143(1)(b) 2 which prohibits a person to permit or cause anyone else to use the motor vehicle unless the said third party insurance is in

\footnotetext{
${ }^{280}$ Centre For CONNECTED \& Autonomous Vehicles, PATHWAy To Driveless Cars: Government Response To CONSUltation On Proposals To SupPort AdVANCED DRIVER AsSistance SysteMs AND AUTOMATED VEHICLES $\S 3.36$ (2017),

https://assets.publishing.service.gov.uk/government/uploads/system/uploads/attachment_data/file/581577/pathw ay-to-driverless-cars-consultation-response.pdf (last visited July 31, 2019).

${ }^{281}$ Cane, supra note 256, 196.

${ }^{282}$ See https://www.lawcom.gov.uk/project/automated-vehicles/ (last visited July 31, 2019). The Commission has recently published its consultation paper and it is expected to publish its final report that will contain its recommendations on the shape of the civil liability system for AV in 2021 - see Government Consultation, supra note 253.

${ }^{283}$ Bank Of England, Potential Impacts Of Autonomous Vehicles On The Uk Insurance Sector 40 (2017 Q1), https://www.bankofengland.co.uk/-/media/boe/files/quarterly-bulletin/2017/potential-impacts-ofautonomous-vehicles-on-the-uk-insurancesector.pdf?la=en\&hash=9E9149D8659F22ABBE9EB22761FF1AC8900B6EAE (last visited July 31, 2019).

${ }^{284}$ Road Traffic Act 1988, c. 52 (U.K).

${ }^{285}$ Directive 2009/103/EC of the European Parliament and of the Council of 16 September 2009 relating to insurance against civil liability in respect of the use of motor vehicles, and the enforcement of the obligation to insure against such liability, 2009 O.J. (L 263) 11 - see supra, 2.5.

${ }^{286}$ Road Traffic Act 1988, supra note 284, § 145 (3).
} 
force in relation to the use of the vehicle by that other person. ${ }^{287}$ If the owner of a vehicle permits it to be used by an uninsured driver and damage is caused by such user, then the owner is not only committing a criminal offence but is also liable for the ensuing damages as a result of the breach of the statutory duty to insure. ${ }^{288}$ In Norman v. Aziz it was clarified that the Motor Insurance Bureau Agreement did not affect the cause of action for breach of statutory duty. ${ }^{289}$ Having said that, the Court of Appeal recently held in Sahin v. Havard that it is not compulsory for insurers to provide cover for such liability under Section 145 and are not required to satisfy a judgment arising out of such liability under Section $151 .{ }^{290}$

In Section 145(3) the Act identifies the minimum, compulsory cover to be offered by motor policies: a policy must insure "such person, persons or classes of persons as may be specified in the policy in respect of any liability which may be incurred by him or them in respect of the death of or bodily injury to any person or damage to property caused by, or arising out of, the use of the vehicle on a road or other public place" in Great Britain and in the EU. ${ }^{291}$ English law does not provide for a limit to the liability insured for death and personal injury, yet a limit of $£ 1,200,000$ per accident in respect of third party property damage has been imposed. ${ }^{292}$. Under Section 161(3) any reference to an accident includes a reference to two or more causally related accidents. ${ }^{293}$ The intention of using such an aggregating provision is to create "a ceiling for all property damage flowing from an occurrence such as, for example, a multiple collision", ${ }^{294}$ although this is debatable. ${ }^{295}$

\subsubsection{Prohibited restrictions of cover}

Section 145(3) must be read in conjunction with Section 148(2) which provides a list of restrictions that are not available to insurers when handling third party claims that fall into the compulsory cover of Section 145 . They are widely drafted and include any term that refers to (a) the age or physical or mental condition of persons driving the vehicle,(b) the condition of the vehicle, (c) the number of persons that the vehicle carries, (d) the weight or physical characteristics of the goods that the vehicle carries,(e) the time at which or the areas within which the vehicle is used, (f) the horsepower or cylinder capacity or value of the vehicle, $(\mathrm{g})$ the carrying on the vehicle of any particular apparatus, or $(h)$ the carrying on the vehicle of any particular means of identification. ${ }^{296}$

Section 148(2) works in practice as follows: "There is no prohibition on the policy containing those exclusions or restrictions, and if it does they are fully operative in first party claims. The

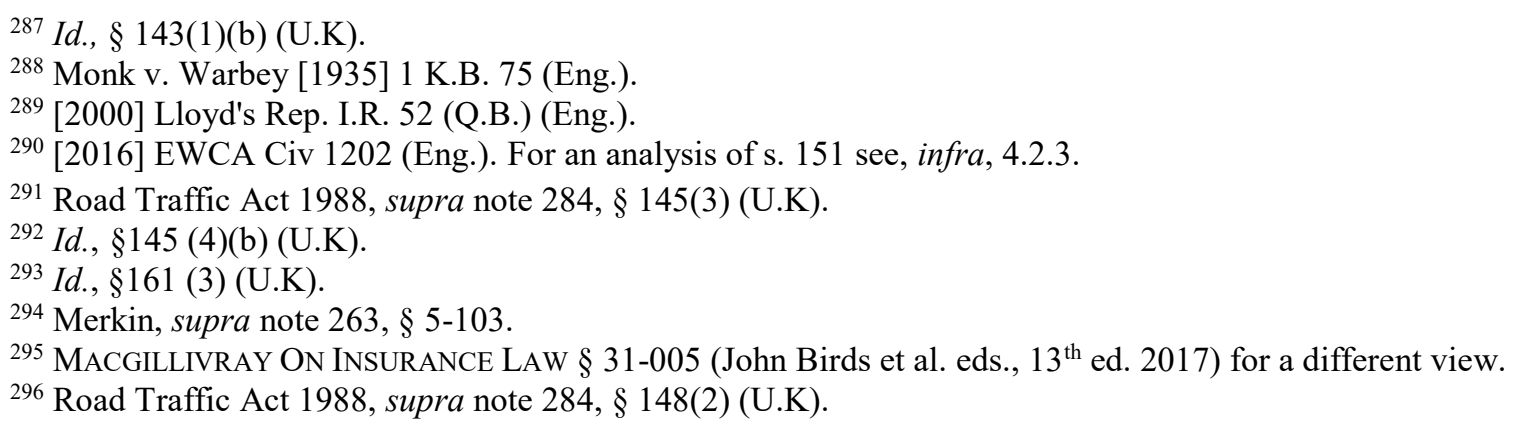


effect of the legislation is to render the relevant terms unenforceable where the assured is faced with a claim by a third party in respect of which he seeks indemnification from his insurers. The terms which are negative are not identified by class in the legislation and would appear to include all provisions whether expressed as restrictions on cover, warranties and conditions precedent to cover or to liability". ${ }^{297}$ Upon payment to the third party, Section 148(4) gives the right to insurers to recover the amount paid despite the restrictions from the insured. ${ }^{298}$

\subsubsection{Main avenue for recovery}

Section 151 constitutes the main avenue for recovery of compensation by a third party under the compulsory cover of Section 145. In essence, it provides that insurers are required to satisfy a judgment that the third party obtained against the insured. This section imposes a far-reaching obligation on insurers, as it makes them liable even in situations where they do not have an obligation to provide cover for the injury or damage under the policy.

They are required to satisfy it a) "[n] otwithstanding that the insurer may be entitled to avoid or cancel, or may have avoided or cancelled, the policy"; 299 b) notwithstanding that the user was uninsured ${ }^{300}$ or was unidentified ${ }^{301}$ or used it without consent, including stealing $\mathrm{it}^{302}$ or did not have a driving licence; ${ }^{303} \mathrm{c}$ ) notwithstanding the injuries or damage to the third party were deliberately inflicted provided that the policy provided cover against this risk. ${ }^{304}$ In the case of theft, the liability of insurers to the passenger is subject to the condition that the passenger did not know or had no reason to believe that i) the vehicle had been stolen or unlawfully taken until after the commencement of his journey, and ii) could not reasonably have been expected to have alighted from the vehicle. ${ }^{305}$

To avoid liability under Section 151, the insurers have available the limited defences of Section 152, namely that a) they were given no notice of the proceedings before or within 7 days of their commencement; ${ }^{306} \mathrm{~b}$ ) execution on the judgment was stayed pending an appeal; ${ }^{307} \mathrm{c}$ ) the policy was cancelled by mutual consent prior to the accident; ${ }^{308}$ and d) a declaration was obtained by the insurers before or within 7 days of the commencement of the main proceedings that they are entitled to avoid the policy on the ground that it was obtained by the non-disclosure

\footnotetext{
${ }^{297}$ Merkin, supra note 263, § 5-167.

${ }^{298}$ Road Traffic Act 1988, supra note 284, § 148(4) (U.K).

${ }^{299} I d ., \S 151(5)$.

${ }^{300} I d$., $\S 151(2)(\mathrm{b})$.

${ }^{301}$ Cameron v. Hussain [2017] EWCA Civ 366 (Eng.) where the vehicle was identified but not the driver.

${ }^{302}$ Road Traffic Act 1988, supra note 124, § 151 (2) (b).

${ }^{303}$ Id., $\S 151(3)$.

${ }^{304}$ Merkin, supra note $263, \S 5-129$ to 5-131.

${ }^{305}$ Road Traffic Act 1988, supra note 284, § 151(4) (U.K).

${ }^{306} I d$., $\S 152$ (1) (a).

${ }^{307}$ Id., $\S 152$ (1) (b).

${ }^{308}$ Id., $\S 152$ (1) (c).
} 
of a material fact, or by a representation of fact which was false in some material particular. ${ }^{309}$ In these cases the third party will be compensated by the Motor Insurance Bureau.

In sections 151(7) and (8) the Act makes provision for the insurer's rights of recourse. When the insurers are liable to pay compensation to a third party caused by a non-insured user, Section 151(8) gives them the right to recover the amount either from the uninsured driver or from the person that permitted the use of the vehicle by an uninsured driver. ${ }^{310}$ The scope of this section was restricted by the case of Churchill Insurance Co. Ltd. v. Wilkinson where the injured passengers had permitted their cars to be used by uninsured drivers giving insurers the right to recover from them any sums payable to them as third parties. ${ }^{311}$ Following referral to the CJEU, the Court of Appeal ruled that Section 151(8) (b) allows recovery from the insured who has permitted the use of his vehicle by an uninsured driver only when the court considers that it is "proportionate... on the basis of the circumstances of the case", 312 namely "the circumstances in which the permission was given, the nature of the accident and the overall competence of the driver". ${ }^{313}$

When the insurers are liable to pay compensation to a third party caused by an insured user, $\mathrm{s}$ 151(7)(b) provides that they can recover from the insured the sum that exceeds the amount for which they would otherwise be liable under the policy. If the loss was caused by a person driving without a valid licence, insurer would be able to recover the entire amount courtesy of Section 151(7)(a).

Under Regulation 3 of the European Communities (Rights against Insurers) Regulations 2002, English law also permits direct actions from third parties against motor insurers, without the need to obtain judgment under Section 151 of the Road Traffic Act 1988. Yet, the main advantage of Section 151 is that it provides cover in the situation where the third party suffered loss from an unauthorised user, namely an uninsured, unidentified, or user without consent. This provision has also reduced the importance of the Motor Insurance Bureau with respect to uninsured or unidentified drivers and the action for breach of statutory duty. ${ }^{314}$

\subsection{Negligence liability for defective products}

The landmark case Donoghue $v$ Stevenson established the duty of manufacturers who sell products that are intended to reach consumers in the form that these left their premises, with no reasonable possibility of intermediate examination, and with the knowledge that the absence of reasonable care in the preparation or putting up of the products will result in an injury to the

\footnotetext{
${ }^{309} I d$., $\S 152(2)$.

${ }^{310}$ Road Traffic Act 1988, supra note 284, § 151(8) (U.K).

${ }^{311}$ Churchill Insurance Co. Ltd. v Wilkinson and Evans v. Equity Claims Ltd [2012] EWCA Civ 1166 (Eng.).

${ }^{312} I d$., at [76] (Aikens LJ).

${ }^{313}$ Merkin, supra note 263, § 5-142.

${ }^{314} I d ., \S 5-02$.
} 
consumer's life or property, to take reasonable care towards consumers. ${ }^{315}$ Tortious liability for defective products is independent of any contractual claim. ${ }^{316}$

\subsubsection{Capacity to sue and to be sued}

Following Donoghue v Stevenson, the duty of care is owned not only to end users, but also to persons in their proximity. ${ }^{317}$

Liable persons can be end manufacturers, ${ }^{318}$ component manufacturers, ${ }^{319}$ suppliers if their functions exceed simple distribution, ${ }^{320}$ repairers ${ }^{321}$ etc.

\subsubsection{Scope of the duty}

The risks posed by the product must have been known or at least reasonably foreseeable by the manufacturer. ${ }^{322}$

Moreover, the user must have used to product exactly as it left the manufacturer, that is in all material features, and use it as it was intended to be used. ${ }^{323}$

The duty of care arises specifically in the context of latent defects, where there is no opportunity for intermediate examination that would have revealed the defect. ${ }^{324}$ It suffices that a third party could have discovered the defect in course of a reasonably anticipated examination. ${ }^{325}$ The manufacturers' duty is continuous. This means that manufacturers have to monitor their products, even after they have been put into circulation, for dangers that may arise from their use, issue adequate post-marketing warnings where necessary, and, in extreme cases, recall

\footnotetext{
315 [1932] AC 562, 599 (Lord Atkins) (HL) (appeal taken from Scot.).

316 Grant v Australian Knitting Mills Ltd [1935] All ER Rep 209, 218 (Lord Wright) (PC) (appeal taken from Austl.).

${ }^{317}$ E.g. Abouzaid v Mothercare (UK) Ltd [2000] EWCA Civ 348 (Eng.) - underage son of buyer of baby pushchair component; Carroll v Fearon [1998] P.I.Q.R. P416 passengers in the car and other road users; Stennett v Hancock [1939] 2 All E.R. 578 (Eng.) - pedestrian hit by flange of lorry wheel; Brown v Cotterill [1934] 51 T.L.R. 21 (Eng.) - child injured by falling tombstone.

${ }^{318}$ E.g. Donoghue v Stevenson [1932] AC 562 (HL) (appeal taken from Scot.).

${ }^{319}$ E.g. Divya v Toyo Tire and Rubber Co Ltd (t/a Toyo Tires of Japan) [2011] EWHC 1993 (Eng.); Evans v Triplex Ltd [1936] 2 All ER 283 (Eng.).

${ }^{320}$ E.g. Fisher v Harrods, [1966] 1 Lloyd's Rep 500 (Eng.) - chemist wholesaler failed to make inquiries to the manufacturers and to warn end users; Herschtal v Stewart and Ardern Ltd [1939] 4 All ER 123 (Eng.) - car dealer providing vehicles that he had reconditioned.

${ }^{321}$ Haseldine v CA Daw \& Son Ltd, [1941] 2 KB 343 (CA) (Eng.) - repairer of an elevator that caused injury. ${ }^{322} \mathrm{M} / \mathrm{S}$ Aswan Engineering Establishment Co v Lupdine Ltd [1987] 1 W.L.R. 1 (Eng.); Muirhead v Industrial Tank Specialities Ltd, [1986] QB 507 (CA) (Eng.).

${ }^{323}$ Grant v Australian Knitting Mills Ltd [1935] All ER Rep 209, 217 (Lord Wright) (PC) (appeal taken from Austl.); M/S Aswan Engineering Establishment Co. v. Lupdine Ltd. and Another, [1987] 1 W.L.R. 1, 23 (Lloyd LJ) (Eng.).

${ }^{324}$ Grant v Australian Knitting Mills Ltd [1935] All ER Rep 209, 218 (Lord Wright) (PC) (appeal taken from Austl.); Carroll v Fearon, Bent and Dunlop Ltd [1998] PIQR P416, 421 (Eng.).

${ }^{325}$ Evans v Triplex Safety Glass Co Ltd [1936] 1 All ER 283, 286 (Eng.).
} 
defective products. ${ }^{326}$ Nevertheless, there is no duty to warn for obvious dangers arising from ordinary use. $^{327}$

\subsubsection{Breach of duty}

Manufacturers owe a duty to take reasonable care, which means that they do not have to ensure absolute safety of their products. ${ }^{328}$ However, in some circumstances the "highest level" of care will be required by the manufacturer. ${ }^{329}$

The risk of the damage must have been foreseeable at the time of that the damage occurred. ${ }^{330}$ Thus, there will be no liability where the scientific and technical knowledge at that time did not enable the discovery of the defect. ${ }^{331}$

English courts have been hesitant to distinguish between design defects and manufacturing defects, ${ }^{332}$ also referred to as 'standard' and 'non-standard' products respectively. ${ }^{333}$ Nonetheless, such distinction has been found useful by some authors, as it brings clarity to handling the cases. ${ }^{334}$ There have also been cases for inadequate instructions and warnings. ${ }^{335}$

As to proof of breach of duty, English courts are hesitant to accept the application of res ipsa loquitur in product liability cases. ${ }^{336}$ Nevertheless, in some instances they accept the use of inferences from known facts for the establishment of the defendant's negligence. ${ }^{337}$ The claimant does not have to indicate the particular individual responsible for the defect in the product nor the particular act of negligence. ${ }^{338}$

\footnotetext{
${ }^{326}$ Carroll v Fearon [1999] E.C.C. 73 (Eng.); Hobbs (Farms) v Baxenden Chemicals [1992] 1 Lloyd's Rep 54 (Eng.).

${ }^{327}$ Bogle v McDonald's Restaurants [2002] EWHC 490 (QB) (Eng.)- risk of being scalded by hot drinks.

${ }^{328}$ Holmes v Ashford [1950] 2 All Eng 76 (CA) (Eng.).

${ }^{329}$ Divya v. Toyo Tire and Rubber Co. Ltd (t/a Toyo Tires of Japan) [2011] EWHC 1993 (QB) (Eng.), which regarded defective car tyre.

${ }^{330} \mathrm{M} / \mathrm{S}$ Aswan Engineering Establishment Co v Lupdine Ltd [1987] 1 W.L.R. 1, 22 (Eng.).

${ }^{331}$ A v National Blood Authority, [2001] EWHC 446 (QB) (Eng.); Abouzaid v Mothercare (UK) Ltd 2000 WL 1918530 (2000) (Eng.).

${ }^{332}$ See Justice Burton in A and Others v National Blood Authority and another [2001] 3 All E.R. 289 (Eng.), para. 39, who prefers a similar distinction between 'standard' and 'non-standard' products at para. 36. However, Justice Hickinbottom considers such distinction as unnecessary and unhelpful in Wilkes v DePuy International Limited [2016] EWHC 3096, para. 94 (Eng.).

${ }^{333}$ A v National Blood Authority, [2001] 3 All ER 289, para. 36 (Eng.).

${ }^{334}$ Christian Witting, STREet On TORTS 395, n.68 (15th ed. 2018); Donal Nolan, Strict Product Liability for Design Defects, 134 Law Quarterly Review 176, 177 (2018).

${ }^{335}$ Holmes v Ashford [1950] 2 All ER 76 (CA) (Eng.) - no negligence proven regarding warnings of manufacturer on hair dye; Bogle v McDonald's Restaurants Ltd, [2002] EWHC 490 (Eng.)- no negligence proven regarding risks of scolding by serving hot coffee and tea.

${ }^{336}$ See Carroll v Fearon, Bent and Dunlop Ltd [1998] PIQR P416, 421 (Eng.).

${ }^{337}$ Grant v Australian Knitting Mills Ltd [1935] All ER Rep 209, 216 (Lord Wright) (PC) (appeal taken from Austl.); Carroll v Dunlop Ltd [1998] PIQR P416, 421 (Eng.); Mason v. Williams \& Williams Ld. and Another [1955] 1 W.L.R. 549, 551-552 (Eng.).

${ }^{338}$ Grant v Australian Knitting Mills Ltd [1935] All ER Rep 209, 216 (Lord Wright) (PC) (appeal taken from Austl.); Carroll v Dunlop Ltd [1998] PIQR P416, 421 (Eng.).
} 
In the context of $\mathrm{AV}$, it is very likely that $\mathrm{AV}$ manufacturers will be required to exercise the "highest level" of care towards third parties, as has been the case in accidents involving conventional vehicles. ${ }^{339}$ The level of scientific and technical knowledge at the time of the alleged breach will be a crucial factor. To the rest, the various aspects of product defects under English law do not differ significantly from the fault-based regime in Germany. It is expected that manufacturers of AV will incur liability under similar circumstances concerning design, manufacturing and instruction defects, as well as product monitoring duties. ${ }^{340}$

Proving breach of duty of care will be challenging in some cases, given the self-learning abilities of AV. Given that English courts are already reluctant to accept application of the res ipsa loquitur in product liability cases, such reluctance could only increase as to highly complex products like AV. Nonetheless, this does not preclude that English courts will accept inferences to establish the manufacturer's negligence.

\subsubsection{Damage}

Recoverable damage includes personal injury and damage to property other than the defective product. Thus, damage to the defective product itself and pure economic loss are not recoverable. ${ }^{341}$ Pre-emptive repairs of the defect are not recoverable under tort, ${ }^{342}$ while damage arising from continued use of the defective article, after the claimant had discovered the defect, may bar recovery. ${ }^{343}$

English courts are very hesitant to award exemplary (punitive) damages and do so only in extreme cases. ${ }^{344}$ Thus far, no punitive damages have been awarded for product liability cases. The English and Scottish Law Commissions remark that only a very determined claimant would be prepared to turn down an offer of compensatory damages to pursue a claim on the remote chance that aggravated or punitive damages would be awarded, because a claimant who rejects an offer under Part 36 of the Civil Procedure Rules and then receives no more than the rejected offer would be liable for the costs of the action from the date of the rejection. ${ }^{345}$

\subsubsection{Causation}

\footnotetext{
339 See supra note 329.

340 See supra 3.2.1.2.

${ }^{341}$ Murphy v Brentwood DC [1991] 1 AC 398 (HL) (appeal taken from Eng.); Muirhead v Industrial Tank Specialities Ltd [1986] QB 507 (CA) (Eng.).

342 Murphy v Brentwood DC [1991] 1 AC 398 (HL) (appeal taken from Eng.); D\&F Estates Ltd v Church Commissioning [1989] AC 117 (HL) (appeal taken from Eng.).

${ }^{343}$ Murphy v Brentwood DC [1991] 1 AC 398 (HL) (appeal taken from Eng.).

${ }^{344}$ According to Rookes v. Barnard and Others [1964] A.C. 1129 (HL) (appeal taken from Eng.) and Cassell \& Co Ltd v Broome [1972] A.C. 1027 (HL) (appeal taken Eng.), punitive damages may be awarded where (a) provided by statute, (b) oppressive, arbitrary or unconstitutional action by servants of the government is involved, (c) the defendant sought to make profit by his/her tort that would exceed any compensation due to the defendant. ${ }^{345}$ Government Consultation, supra note $246, \S 6.97$.
} 
Recoverable are only damages for which the claimant establishes, on the balance of probabilities, that they are a reasonably foreseeable consequence of the breach of duty. ${ }^{346}$ No causation is proven if other probable causes have not been eliminated. ${ }^{347}$

In accidents involving AV, proof of causation by claimants is expected to be challenging, given the complexity and the self-learning abilities of AV. Evidentiary alleviations provided by courts to claimants could be crucial for the success of claims.

\subsection{Liability, insurance and automated vehicles in the UK}

\subsubsection{A new insurance paradigm}

The Bank of England predicts that the introduction of AV will cause the motor insurance market to contract by $21 \%$ by $2040 .{ }^{348}$ This contraction is expected to come from the ability of $\mathrm{AV}$ technology to reduce low-speed accidents, thereby removing many of the smaller bumperto-bumper type incidents. ${ }^{349}$ Nonetheless, the Bank estimates that that the cost of treating severe bodily injury claims will continue to increase relative to property damage and technology inflation. ${ }^{350}$

It is also becoming increasingly obvious to insurers that AV manufacturers consider entering the insurance market in the future. The main reason behind such development is to use premium income to counterbalance the erosion of the after-markets parts business, which is expected as a result of the fewer accidents. ${ }^{351}$ The argument goes that car manufacturers already "use financing and warranties to enhance profits at the point of sale; insurance could be a similar business that provides for some annuity in revenues and continuity in customers relationships". ${ }^{352}$ It has been suggested that this can be achieved by either acting "as an insurance company with many functions outsourced" or even by becoming "a fully integrated insurance company that owns and runs the distribution, operations, and financial management". ${ }^{353}$ Either way manufacturers i) will not be required to share driving data with third party insurers; and ii) will be able to "price insurance more precisely and share safety gains with clients". ${ }^{354}$ Such a development has also been noted by the Bank of England which expects that synergies between car manufacturers and insurers will increase. ${ }^{355}$ The implication

\footnotetext{
${ }^{346}$ See McTear v Imperial Tobacco Ltd, 2005 [2005] Scots CSOH 69 (Scot.); Carroll v Fearon, Bent and Dunlop Ltd [1998] PIQR P416, 426-427 (Eng.).

${ }^{347}$ Evans v Triplex Safety Glass Co Ltd [1936] 1 All ER 283, 286.

${ }^{348}$ Bank of England, supra note 283, 40.

${ }^{349} I d ., 44$.

${ }^{350} \mathrm{Id}$.

351 KPMG, The Chaotic Middle. The Autonomous Vehicle And Disruption In The Automobile INSURANCE 26 (2017), https://assets.kpmg.com/content/dam/kpmg/us/pdf/2017/06/chaotic-middle-autonomousvehicle-paper.pdf (last visited July 31, 2019).

352 Id.

${ }^{353} I d ., 27$.

${ }^{354} I d$., 26.

${ }^{355}$ Bank of England, supra note 283, 45.
} 
is that insurers who fail to reach agreement with manufacturers will find it challenging to sustain their business model. ${ }^{356}$

The bottom line is that the motor insurance market is destined for a transformation in terms of market structure, ways of placing and rating risks, as well as handling claims. In that respect, we are witnessing a paradox. On the one hand, insurers are becoming aware that the use of AV will require a significant transformation of the sector with many being forced to quit the motor insurance market. On the other hand, the new technology promises to significantly reduce costs, which is expected increase margins of profitability for the insurers that adapt to the new reality.

British insurers have opted to tackle this paradox by supporting the development of AV technologies either in partnership with car manufacturers or by undertaking their own research and development. ${ }^{357}$ Partnering with car manufacturers on AV trials is crucial as it helps them understand the impact on vehicle accident rates. ${ }^{358}$ At the same time, it offers them the opportunity to identify ways to retain the customer relationship regarding insurance. It enables them to offer an insurance product that is appealing enough to dissuade car manufacturers from creating a one-stop-shop for car and insurance sales. What is clear, though, is that AV technology will cause disruption in the insurance market and what we are currently witnessing is its slow transformation.

\subsubsection{A new framework for insurance law}

The British Parliament passed the Automated and Electric Vehicles Act 2018 to facilitate the development of AV and the evolution of the insurance market. The aim of the Government is to make as little changes as possible to the existing compulsory scheme of insurance having rejected the proposal for an overhaul of the motor insurance and liability framework. ${ }^{359}$

\subsubsection{Registry of AV and levels of automation}

The Act provides for the creation of a registry of AV that fall into its scope. ${ }^{360}$ It does not indicate the level of automation that a vehicle will be required to have to be registered, but states that AV will be listed if they are "...designed or adapted to be capable, in at least some circumstances or situations, of safely driving themselves". ${ }^{361}$ The intention is that the registry will cover vehicles that allow the passenger to hand "full control and responsibility to the vehicle..., without the need for the driver to intervene or monitor, for some, or all, of the

\footnotetext{
${ }^{356} I d$.

357 See the research undertaken by the Thatcham Research Centre, which was established by motor insurers in 1969 "to contain or reduce the cost of motor insurance claims whilst maintaining safety standards", https://www.thatcham.org/about (last visited July 31, 2019).

${ }_{358}$ Bank of England, supra note 283, 46.

${ }^{359}$ See Government consultation, supra note $280, \S 1.10$.

${ }^{360}$ Automated and Electric Vehicles Act, supra note 252, § 1.

${ }^{361} I d$., $\S 1(\mathrm{a})$.
} 
journey". ${ }^{362}$ The English and the Scottish Law Commissions clarify that Government policy is that only vehicles which can achieve a minimal risk condition will be listed in the List of the AEV Act; in other words registered will be only the vehicles that are capable of coming to a safe stop, in the case of system failure. ${ }^{363}$

Such autonomy is to be distinguished from vehicles where the driver "must monitor and remain ready to take control from the vehicle at all times". ${ }^{364}$ The latter ones remain outside the scope of the Act and will be treated as conventional vehicles for liability and insurance purposes. The creation of this Registry aims to provide certainty to the insurance industry. Identifying the relevant vehicles by type will leave no doubts as to the type of compulsory insurance required.

The Act does not refer to the AV taxonomy of SAE International when it comes to the Registry. ${ }^{365}$ Yet, it seems that the intent is to cover Levels 4 and 5 where the vehicle has control over the navigation and the human agent is either a passenger (setting the itinerary in Level 5) or takes over control in strictly pre-defined situations (Level 4) ${ }^{366}$. The inclusion of Level 4 automation is evident from Section 2(a) of the Act which provides that the liability of insurers is triggered, when among other things, "an accident is caused by an automated vehicle when driving itself" which is further defined as "operating in a mode in which it is not being controlled, and does not need to be monitored, by an individual". 367

The wording of this provision leaves the possibility open to cover Level 3 vehicles as they can perform all aspects of the driving task. Yet, it is unlikely that they will be included in the Registry, the reason being that insurers consider the risks associated with this level of automation too great to tolerate. ${ }^{368}$ As such, the British insurance market has expressed a strong view about the insurability of Level 3 vehicles: "a way should be found to bypass Level 3 where a driver does not need to monitor the dynamic driving conditions, nor the driving environment at all times, but must always be in a position to resume control". ${ }^{699}$ Insurers are concerned that Level 3 vehicles will increase the level of accidents because drivers will either ignore the request to intervene or will not intervene quickly enough to manage the driving conditions. As Level $3 \mathrm{AV}$ are already on the market ${ }^{370}$ the compromise achieved is to exclude them from the Registry and as such fall into the pre-existing fault-based liability regime.

\footnotetext{
${ }^{362}$ Government Consultation, supra note 253, $\$ 2.5$.

${ }^{363} I d$., $\$ 2.56$ and $\$ 3.25$.

${ }^{364} \mathrm{Id}$.

${ }^{365}$ See supra Introduction.

${ }^{366}$ See Letter from Baroness Sugg to Lord Blencathra, Chairman of the Delegated Powers and Reform Committee regarding whether the Automated and Electric Vehicles Bill's provisions cover Level 3 vehicles (Mar. 13, 2018) http://data.parliament.uk/DepositedPapers/files/DEP20180517/Baroness_Sugg_to_Lord_Blencathra-AEV_Bill_DPRRC_Report.pdf (last visited July 31, 2019).

${ }_{367}$ Automated and Electric Vehicles Act, supra note 252, § 8(a) (U.K.) - emphasis added.

${ }^{368}$ House Of Lords Science And TeChNology Select CommitTeE, ConNeCTED ANd Autonomous VEHICLES: THE FUTURE? at 7, $\$ 23$ (HL PAPER 115, 2017), https://publications.parliament.uk/pa/ld201617/ldselect/ldsctech/115/115.pdf (last visited July 31, 2019). ${ }^{369} I d$., at 4.

${ }^{370}$ See Michael Taylor, The Level 3 Audi A8 Will Almost Be The Most Important Car In The World, ForBES (Sep 10, 2017, 07:31 AM), https://www.forbes.com/sites/michaeltaylor/2017/09/10/tthe-level-3-audi-a8-willalmost-be-the-most-important-car-in-the-world/\#48c5e410fb3d (last visited July 31, 2019).
} 


\subsubsection{Strict liability of insurers}

The core arrangement of the Act is to impose a system of strict liability on the insurers of AV. This is a remarkable feature under UK law, in which strict liability is treated as anomalous. ${ }^{371}$ Section 2 provides that where damage to the driver, passenger or a third party is caused by an $\mathrm{AV}$ when driving itself, the insurer is liable for that damage, provided the vehicle was insured at the time of the accident. ${ }^{372}$ Once an insurer has settled a claim with the injured party it may then reclaim damages from other parties liable for the accident, e.g. the manufacturer of the vehicle. ${ }^{373}$ Hence, the AEV Act creates a wholly new form of liability which arises directly on insurers. ${ }^{374}$

Considering the fault liability framework applicable to conventional cars, ${ }^{375}$ this provision brings quite a change to the legal landscape and brings English law closer to the continental European systems. The choice of strict liability is certainly a step to the right direction and reflects popular practice in regulating nascent activities. One of the basic benefits of the strict liability system is that it reduces the need for the claimant to delve into the way the new technology works in order to establish fault, an exercise that is both time-consuming and expensive. Such a choice was also made in the early days of aviation with a "presumed-fault" liability regime introduced in $1929 .{ }^{376}$

In the context of the Act, claimants are required to prove that they suffered property damage or personal injury as a result of an accident caused by an AV. The Law Commission and the Scottish Law Commission observe that where an accident is caused by a defect in the vehicle, the starting point is that the insured person (that is the driver or their employer) is liable for the accident. However, were the defect is latent and not discoverable by the exercise of reasonable care, it is open to the insured to show that they took all reasonable care in the circumstances. ${ }^{377}$ For conventional vehicles, this is a high threshold: to escape liability, the defendant needs to show considerable evidence of the inspections and repairs carried out. ${ }^{378}$ Therefore, in practice, drivers' insurers continue to pay claims where a vehicle defect may be the cause of an accident, mainly because it is so difficult to distinguish between driver fault and vehicle defects. ${ }^{379}$

The use of the term "accident" in Section 2 (1) (c) might prove problematic. ${ }^{380}$ What qualifies as "an unusual or unexpected event" can be used as a way of introducing a defence by inquiring into the nature of the vehicle's behaviour. This might not be problematic for a claim by a third-

\footnotetext{
${ }^{371}$ Ken Oliphant, Liability for Road Accidents Caused by Driverless Cars, 2019 Sing.

Comp. L. Rev. 190, 196 (2019).

372 Automated and Electric Vehicles Act, supra note 252, § 2(a) (U.K.).

${ }^{373}$ Government Consultation, supra note 253, § 6.2.

${ }^{374} I d ., \S 6.15$.

375 See supra Section 4.1 .

${ }^{376}$ See Convention for the Unification of Certain Rules Relating to International Carriage by Air, opened for signature Oct. 12, 1929, 49 Stat. 3000, 137 L.N.T.S. 11 (Warsaw Convention).

${ }^{377}$ Henderson v Henry E Jenkins \& Sons [1970] AC 282

${ }^{378}$ Government Consultation, supra note $253, \S 6.9$.

${ }^{379} I d ., \S 6.12$.

${ }^{380}$ Automated and Electric Vehicles Act, supra note 252, § 2(1)(c) (U.K.).
} 
party pedestrian who will be foreign to the vehicle's operation. Yet, it might be raised in personal injury claims by the passengers of the AV following a collision. Did they suffer injury from an "accident", if the AV did not malfunction or if they could have expected the reaction of the AV?

This is similar to questions raised in claims by aircraft passengers who suffer damage to their genitals because they flush the aircraft toilet while sitting down. The toilet operates properly and the regulators require no relevant warnings. Is the injury caused by an "accident", i.e. an unusual or unexpected event, considering that there was no malfunction of the aircraft and there was no obligation to have a written warning in the toilet? To avoid such hair-splitting questions that tend to delay the compensation process, a less complicated wording would have been advisable in Section 2(1), namely that "where death or personal injury is caused by an automated vehicle when driving itself and the vehicle is insured at that time, the insurer is liable for the damage".

The new Act does not make provision for accidents caused by uninsured owners of AV when they are driving themselves. It only provides that the uninsured owner is liable if the AV causing the damage is owned and under the control of several public bodies identified in Section 144(2) of the Road Traffic Act 1988, as well as vehicles in the public service of the Crown $^{381}$. In the former case, it is expected that the Motor Insurance Bureau will pick up the bill, if the owner is not capable of paying out the claim. It has been rightly suggested that currently the Bureau cannot cover such damage, as there is no liability for the uninsured owner under the new Act. ${ }^{382}$ To fill this gap the British Government is at the time of writing in discussions with the Bureau. ${ }^{383}$

\subsubsection{Permitted exclusions of liability}

Reflecting the compulsory nature of third party insurance, Section 2(6) provides that "liability under this section may not be limited or excluded by a term of an insurance policy or in any other way" except as provided in Section $4 .{ }^{384}$ Section 2(6) is wider than Section 148(2) of the Road Traffic Act which identifies the categories of "prohibited" terms. ${ }^{385}$ It has been noted that Section 2(6) streamlines all claims to insurers, creating, as such, two layers of victims: victims of conventional car accidents will "be seeking compensation under the Motor Insurance Bureau's Arrangements and [victims of AV] under the insurance policy". ${ }^{386}$

\footnotetext{
${ }^{381} I d ., \S 2(2)$.

382 Government Consultation, supra note $253, \S 6.19$.

${ }^{383} I d$.

${ }^{384}$ Automated and Electric Vehicles Act, supra note 252, §2 (6).

${ }^{385}$ See supra Section 4.2.2.

${ }^{386}$ Written evidence submitted by Rob Merkin QC et al (AEVB 10) to the British Parliament on the Automated and Electric Vehicles Bill (2017), https://publications.parliament.uk/pa/cm201719/cmpublic/automated/memo/aevb10.htm (last visited July 31, 2019).
} 
Section 4 permits insurers to exclude or limit their liability to the insured for damage directly resulting from "(a) software alterations made by the insured person, or with the insured person's knowledge, that are prohibited under the policy, or (b) a failure to install safety-critical software updates that the insured person knows, or ought reasonably to know, are safetycritical" 387 . In case the software alteration injures an insured person who is not the holder of the policy, such as a passenger, insurers will not be able to invoke the said section, unless the passenger knows that the software alterations are prohibited under the policy. ${ }^{388}$

If insurers are required to pay compensation to a third party who is not insured under the policy for an injury caused by an accident that is the direct result of prohibited software alterations or failure to install safety-critical software updates, they can recover the amount from the insured. ${ }^{389}$ If insurers attempt to recover from an insured person who is not the holder of the policy for the said accident, they can only do so if the person in question knew that the software alterations were prohibited by the policy. ${ }^{390}$

\subsubsection{Contributory negligence}

The Act also makes provision for contributory negligence by clarifying that the Law Reform (Contributory Negligence) Act 1945 is applicable. ${ }^{391}$ Considering that the insurers would not have actually contributed to the damage, the new Act makes "a quite difficult to follow" assumptions in ss 3(1) and 6(3): "first, that the claim is brought against someone other than the insurer, and secondly that the insurer is at fault because of the behaviour of the automated vehicle",392.

As to the latter assumption, the provisions on contributory negligence have been criticized, because they might suggest that the courts should treat the issue as if a human driver had been involved, which could lead to inappropriate solutions under certain circumstances. The Law Commission and the Scottish Law Commission mention an example in which a person cycling without lights at night is hit by an AV. They observe that while a human driver would have had difficulty in seeing the unlit cyclist, the failure to have lights might have very little effect on an automated vehicle equipped with LIDAR. The concern is that section 3(1) could be used to apply standards of human fault to quite different claims involving automated vehicles. ${ }^{393}$ This presents a difficult logic problem, as the appropriate reduction would depend i.a. on the degree of the at-fault driver's negligence and possibly the degree of the product defectiveness which cannot be specified under the AEV Act. ${ }^{394}$

\footnotetext{
${ }^{387}$ Automated and Electric Vehicles Act, supra note 252, § 4 (1)(a) - (b).

${ }^{388} I d$., $\S 4$ (2).

${ }^{389} I d ., \S 4(3)-(4)$.

${ }^{390} I d ., \S 4(5)$.

${ }^{391} I d ., \S 3(1)$.

${ }^{392}$ Government Consultation, supra note 253, $\S \S 6.33-6.36$.

${ }^{393} I d$., $§ 6.37$.

${ }^{394}$ Oliphant, supra note 371, 195.
} 


\subsubsection{Rights of recourse}

Section 5 of the Act provides that the insurer or owner of the AV has, upon settling the amount of his liability with the injured party, a right of recourse against any party responsible for the accident, including the manufacturer of the $\mathrm{AV} .{ }^{395}$ If the amount they recover for the responsible party exceeds the amount to be paid to the injured party, they are liable to the injured party for the excess. ${ }^{396}$ The government believes that it is not "in a manufacturer's commercial interest to be unhelpful to insurers in determining liability or paying recovery claims; ultimately, insurers could potentially cease offering insurance products for the manufacturer's vehicles if their route to recovery was consistently blocked". 397

The assumption that the Government makes is correct, provided insurers remain on a commercial par to manufacturers. As often happens, this is not always the case. It has been witnessed that manufacturers tend to absorb the cost of accidents in nascent industries to promote its development. However, they become protective of their products by means of onesided indemnity clauses, once the products become established and their liabilities increase. ${ }^{398}$ Whether a similar development will take place in the case of AV will very much depend on the competitiveness of the manufacturers' market and the insurance role of manufacturers.

\subsubsection{Evaluation}

The Act constitutes a step to the right direction, yet it is not as ground-breaking as it has been hailed.

We question the legislative choice to impose strict liability only when the accident is caused by an automated vehicle "driving itself", i.e. when it is not being controlled, and does not need to be monitored, by an individual". ${ }^{399}$ In principle, the division follows the philosophy behind the drafting of the Act, namely to impose a strict liability regime only when the accident results from the malfunction of the AV. As such, the aim is to create a dividing line between human and technological errors with the former falling into the pre-existing fault-based liability system.

This is feasible in Level 5 where it is expected that the passenger will undertake no driving or monitoring tasks. In that respect, the dividing line would be clearly drawn as there will be no interference from the passenger. Yet, there will be situations in Level 4 where the driver is requested to either take control or closely monitor the automatic driving. Section 2 provides that death or bodily injury caused by the AV during this period will be determined by the preexisting fault system. This way the Act limits the scope of Section 1, since the strict liability

\footnotetext{
${ }^{395}$ Automated and Electric Vehicles Act, supra note 252, § 5.

${ }^{396}$ Id., $\S 5(3)$.

${ }^{397}$ Government Consultation, supra note $253, \S 3.14$.

${ }^{398}$ MARGO ON AVIATION INSURANCE $§ 1.13$ (Tim Marland et al. eds., $4^{\text {th }}$ ed. 2014 ).

${ }^{399}$ Automated and Electric Vehicles Act, supra note 252, § 8 (1) (a) (U.K.).
} 
regime does not apply to the entirety of cars listed in the Registry, but only while they are selfdriving as defined in the Act.

This is a rather significant restriction of the scope of the Act that puts third-party victims in a disadvantageous position as their recovery depends on the mode of operation at the time of the accident - a rather fortuitous occurrence from their standpoint. It is expected that the monitoring requirement will slow down the recovery process, as it will become essential to identify the exact moment that monitoring was not required any more.

This way, the Act puts the risk of monitoring on the third-party claimants rather than the insurers. A clear-cut solution would have been for the cars registered in the scheme of Section 1 to be covered by strict liability in any situation other than being driven by passenger human driver. In the alternative, the fault liability regime could have been applicable solely to claims filled by the driver for personal injury caused while operating the car. This alternative would leave third party claims in the strict liability regime irrespective of the mode of operation of the vehicle (automatic or manual, monitored or not).

The ingredients for the former alternative are already in the Act. Section 3(2) provides that insurers are not liable to the person in charge of the vehicle "where the accident that it caused was wholly due to the person's negligence in allowing the vehicle to begin driving itself when it was not appropriate to do so". 400 This provision limits the scope of application of the contributory negligence provision of the Act by exonerating the insurers from liability when the accident is caused by the car being in self-driving mode in breach of the manufacturer's guidelines or the prevailing driving conditions. Yet, it can be used to create a clearer dividing line between third party claims (always under strict liability) and human errors of the person in charge of the vehicle (fault-based liability).

The Act focuses on the behaviour of the driver rather than the capabilities of the car. Having a car registered in the scheme of Section 1 will not automatically trigger the application of strict liability, but instead the applicable legal regime will be determined by reference to the mode of operation of the vehicle at the time of the accident. As such, the Act seems to be mostly relevant for Level 5 vehicles where there will be limited, if any, human interference in its operation. In all other vehicles, the strict liability regime will only come into force when the conditions permit the vehicle to be on unmonitored, self-driving mode. While this is reasonable in terms of claims filled by the driver, it is debatable whether the same regime should be applicable to third party claims as the accident will be caused by a failure in the interaction between the machine and the driver.

In that respect, the Act is a step to the right direction, albeit a small one. Its drafters intended to limit the application of strict liability to technological malfunctions, leaving behavioural mishaps to be determined by reference to fault liability. Such a policy decision appropriate as it is for Level 5 automation, it has the potential to increase litigation costs for third party claims involving Level 4 vehicles which permit manual control.

${ }^{400} I d ., \S 3(2)$. 
This policy choice can be explained by the initial decision of the Government to include product liability in the scope of the Act. Initially, the Government suggested to "extend compulsory motor insurance to cover product liability to give motorists cover when they have handed full control over to the vehicle". ${ }^{401}$ In essence, the Government suggested a system where liability cover would be in place during the manual operation and product liability cover during the autonomous operation. This proposal was rejected during the consultation process. ${ }^{402}$ At the same time, it can also be explained as a veiled attempt by the Government to dissuade any arguments supporting the generalised application of strict liability regime to motor vehicles.

Furthermore, it is noteworthy that the initial conclusion of the English and Scottish Law Commissions is that litigation over manufacturers' or other suppliers' liability will play a relatively limited role in compensating victims, setting standards or allocating blame for defective automated vehicles for three reasons:

(1) The main avenue for providing compensation will be through insurers, under the provisions of Part 1 of AEV Act. Litigation against manufacturers will then be a commercial matter for the insurer;

(2) The main means of setting standards will be through regulation. If the system passes relevant testing (and there is no impropriety by the manufacturer), it is unlikely that the courts would themselves seek to impose a different, more stringent standard.

(3) The main means of allocating blame will be through the criminal justice system.

The relatively low level of damages for deaths, coupled with the difficulties of obtaining aggravated or punitive damages, means that civil litigation will not be an important form of accountability. ${ }^{403}$

The AEV Act is certainly not the end of the story for English law. We will have to wait for the recommendations of the Law Commission in 2021 as to the shape of the civil liability regime for AV.

\section{Third-party liability regimes in other European States}

The European Commission observes that, apart from national laws implementing the PLD, all EU MS attribute liability for damages caused by motor vehicles to the keeper or the driver of the vehicle. Liability can be fault-based, including cases where the fault of the keeper/driver is rebuttably presumed, or risk-based, where the keeper/driver is strictly liable for creating the risk associated with the operation of a motor vehicle on public streets. ${ }^{404}$ In some States, both categories of third-party liability regimes can exist, i.e. general fault-based tort liability rules

\footnotetext{
${ }^{401}$ Government consultation, supra note $280, \S 2.9$.

${ }^{402} I d ., \S \S 3.8-3.10$.

${ }^{403}$ Para. 6.115.

${ }^{404}$ See Commission Staff Working Document, Liability for emerging digital technologies, SWD (2018) 137 final, 25 April 2018, available at https://ec.europa.eu/digital-single-market/en/news/european-commission-staffworking-document-liability-emerging-digital-technologies (last visited June 5, 2018), pp. 8 and 14, with indicative citations of national provisions.
} 
and special strict liability rules on vehicle keeper or driver liability, similar to the German legal system.

The generic nature of these rules, either broad (all torts) or narrow (all vehicles), indicates that they will be applicable to accidents involving AV.

\section{Evaluation of the legal landscape in Europe}

In Europe, third-party liability for AV is governed mainly by the PLD, as well as by general tort liability rules on defective products and traffic accidents. The full-harmonization character of the PLD creates a pre-emption of EU MS regarding the introduction of special productliability on AV. Nevertheless, in the absence of special rules, eventual legal lacunae are likely to be covered by the development of special case-law on AV accidents, which will interpret general tort rules on defective products in the light of the particularities of AV.

The PLD seems adequate to cover AV cases, in general, yet there are grey areas, especially regarding the notion of 'product' and 'defect'. National regimes on product liability and road traffic liability are diverse and comprise often a combination of regimes of fault liability and strict liability. Moreover, they may interact with special rules on product safety in a variety of ways, e.g. by determining the scope of negligence or by providing the legal basis for liability for breach of statutory duties. All these factors create legal uncertainty.

Legislative initiatives on AV so far stem from countries with strong industries, i.e. Germany, one of the biggest world carmakers, and England, which hosts a huge insurance-services industry. The existence of such industries in the respective countries is a parameter of the regulatory solutions adopted in each country. ${ }^{405}$

The UK has been very active in the development of AV technology, but, at the same time, is protective of its insurance industry, which is one of the main contributors to its economy. There is no doubt that insurers will have a major saying in the consultation recently opened on the liability system for AV. Its success will very much depend on their endorsement rather than the fine balancing of interests between the various parties involved, namely manufacturers, users, insurers as well as third parties.

The decision of the UK Government to produce an Act that moves to a system of strict liability is certainly a step to the right direction and it might be indicative of the direction that the liability system currently under consultation might take. Yet it is not as ground-breaking as it has been hailed. It is arguable that a clearer solution would have been for strict liability to be imposed for any accidents to third parties caused by the vehicles registered in the scheme of Section 1, irrespective of the mode of operation. Considering the provision on contributory negligence, such an arrangement would provide full protection to third parties from the malfunction of the vehicle and/or the negligence of the driver, while the insurers would be able

\footnotetext{
405 The German government has explicitly stated as a policy objective the promotion of the German car industry see Bundesregierung [Federal Government], supra note 143, 12-13.
} 
to defend claims based on the pedestrian's behaviour. At the same time, we believe that rights of recourse shall not be left to market forces but be regulated in a manner that create a levelplaying field between insurers and manufacturers.

\section{A brief overview of the law in the US}

US Federal policy on AV is laid down mainly in two policy documents of the National Highway Traffic Safety Administration (NHTSA) and the United States Department of Transportation. ${ }^{406}$ It aims to promote innovation and facilitate the testing, introduction and use of Automatic Driving Systems, as well as to improve roadway safety. The guiding principles of the US policy are, among others, to prioritize safety, remain technology neutral, modernize regulations and encourage a consistent regulatory environment. ${ }^{407}$

While the Federal Government is responsible for regulating the safety performance of vehicles and vehicle equipment, as well as their commercial operation in interstate commerce, States and local governments are responsible for licensing drivers, establishing rules of the road, and formulating policy in tort liability and insurance. ${ }^{408}$ Thus, tort liability and related insurance issues for road traffic accidents are determined mainly by state laws.

The investigation reports of the National Transportation Safety Board (NTSB) on the fatal accidents of Tesla in Florida and Uber in Arizona are particularly enlightening as they provide a first glance of how liability rules may be applicable to AV accidents.

In the former case, a Tesla Model S 70D car, traveling eastbound on US Highway 27A (US27A), struck a refrigerated semitrailer powered by a Freightliner Cascadia truck-tractor. At the time of the collision, the truck was making a left turn from westbound US-27A across the two eastbound travel lanes onto a local paved road. The car struck the right side of the semitrailer, crossed underneath it, and then went off the right roadside at a shallow angle. The impact with the underside of the semitrailer sheared off the roof of the car. The NTSB report concluded that the probable cause of the crash was the truck driver's failure to yield the right of way to the car, combined with the car driver's inattention due to overreliance on vehicle automation, which resulted in the car driver's lack of reaction to the presence of the truck. ${ }^{409}$

In the latter case, an SUV test vehicle, modified with an Automated Driving System and with a human operator at the driver's seat for emergency cases, hit a pedestrian, who walked on the road pushing her bicycle. The NTSB found that the probable cause of the accident was the

\footnotetext{
406 NATIONAL HighWAY TRAFFIC SAFETY ADMINISTRATION (NHTSA), UNITED STATES DEPARTMENT OF TrANSPORTATION, AUTOMATED DRIVING SYSTEMS 2.0: A VISION FOR SAFETY (2017),

https://www.nhtsa.gov/sites/nhtsa.dot.gov/files/documents/13069a-ads2.0_090617_v9a_tag.pdf (Nov. 27, 2019); Id., PREPARING FOR THE FUTURE OF TRANSPORTATION: AUTOMATED VEHICLES 3.0, Oct. 4, 2018, https://www.transportation.gov/av/3 (Nov. 27, 2019).

${ }_{407}$ Automated vehicles 3.0, supra note 406, iv-v.

$408 I d$., at 5.

${ }^{409}$ NTSB, Collision Between a Car Operating With Automated Vehicle Control Systems and a TractorSemitrailer Truck Near Williston, Florida May 7, 2016, Accident Report NTSB/HAR-17/02 PB2017-102600, Sept. 12, 2017, at 1-2 and 42, https://dms.ntsb.gov/public/59500-59999/59989/609449.pdf (Nov. 26, 2019).
} 
failure of the vehicle operator to monitor the driving environment and the operation of the automated driving system because she was visually distracted throughout the trip by her cell phone. $^{410}$

We will attempt to briefly present the main tendencies that seem to exist in the US, with reference also to the above-mentioned accident investigation reports. We conclude this part with a comparison between the US and EU law.

\subsection{Liability for AV in the US}

Third-party liability for AV could be based on product liability or on road traffic negligence. Motor insurance issues play also a major role.

\subsubsection{Product liability}

There is no uniform federal legislation enacted on product liability. Nevertheless, to encourage approximation among state laws, the US Department of Commerce has published a Model Uniform Products Liability Act (MUPLA), ${ }^{411}$ while the American Legislative Exchange Council (ALEC) has also adopted model legislation that has influenced some states in the codification of their product liability laws. ${ }^{412}$ Thus, the exact requirements for establishing liability vary from state to state, yet some states have created statutory causes of action which replace traditional common-law theories. ${ }^{413}$

\subsubsection{Product liability theories}

There are two main legal bases or theories for extra-contractual product liability claims in the US: negligence and strict liability.

Negligence is unreasonable conduct, as measured against the conduct of a reasonable prudent manufacturer in the same or similar circumstances. ${ }^{414}$ Reasonable care is established by reference to the risks arising from the use of the product, balancing the costs of improving safety against the foreseeable safety benefits by such improvement. ${ }^{415}$ Proving negligence, especially for manufacturing defects, is often challenging, which makes negligence not widely used anymore. However, at least in manufacturing defects, courts often allow juries to infer

\footnotetext{
${ }^{410}$ NTSB, Collision Between Vehicle Controlled by Developmental Automated Driving System and Pedestrian Tempe, Arizona, March 18, 2018, HWY18MH010, at 1 and 4, https://www.ntsb.gov/news/events/Documents/2019-HWY18MH010-BMG-abstract.pdf (Nov. 26, 2019). ${ }^{411}$ Model Uniform Products Liability ACT, 44 Fed. Reg. 62714 (1979).

412 Product Liability Act, ALEC https://www.alec.org/model-policy/product-liability-act/ (Dec. 2, 2019)

${ }^{413}$ Sean P. Wajert, Product Liability Claims, Defenses, and Remedies, Westlaw Practical Law, Practice Note, at $* 6$.

${ }^{414}$ David G. Owen, Manufacturing Defects, 53 S.C.L.Rev. 851, 861 (2002).

${ }^{415}$ Id.
} 
negligence from the existence of the defect. ${ }^{416}$ Negligence can be mainly used to found claims for post-sale failure to warn or to recall. ${ }^{417}$

Strict product liability is the dominant theory for personal injury claims against manufacturers. ${ }^{418}$ The majority of US case law on strict liability follows the formulation of $\S 402 \mathrm{~A}$ of the Restatement (Second) of Torts, which reads:

“(1) One who sells any product in a defective condition unreasonably dangerous to the user or consumer or to his property is subject to liability for physical harm thereby caused to the ultimate user or consumer, or to his property, if

(a) the seller is engaged in the business of selling such a product, and

(b) it is expected to and does reach the user or consumer without substantial change in the condition in which it is sold.

(2) The rule stated in Subsection (1) applies although

(a) the seller has exercised all possible care in the preparation and sale of his product, and

(b) the user or consumer has not bought the product from or entered into any contractual relation with the seller."

The Restatement (Third) on Product Liability has adopted a simpler formulation: "One engaged in the business of selling or otherwise distributing products who sells or distributes a defective product is subject to liability for harm to persons or property caused by the defect."

\subsubsection{2 'Defect'}

There are three types of defect: manufacturing defects, design defects and marketing defects. ${ }^{419}$ In the automotive sector there is also the doctrine of crashworthiness.

A manufacturing defect exists when the product departs from its intended design and specifications, owing to errors in the production procedure. ${ }^{420}$ According to the Restatement (Third) on Product Liability, a product contains a manufacturing defect when the product departs from its intended design even though all possible care was exercised in the preparation and marketing of the product. ${ }^{421}$

\footnotetext{
${ }^{416} I d$. See also Restatement (ThiRd) OF TorTs: Prod. Liab.§ 3 (AM. LAw InST.1998): "It may be inferred that the harm sustained by the plaintiff was caused by a product defect existing at the time of sale or distribution, without proof of a specific defect, when the incident that harmed the plaintiff: (a) was of a kind that ordinarily occurs as a result of product defect; and (b) was not, in the particular case, solely the result of causes other than product defect existing at the time of sale or distribution.

${ }^{417}$ See Restatement (ThIRD) OF TORTS: Prod. Liab. $\S \S 10$ and 11 (Am. LAW InSt.1998).

${ }^{418}$ Kevin Funkhouser, Paving the Road Ahead: Autonomous Vehicles, Products Liability and the Need for a New Approach, 2013 UTAH L. Rev. 437, 445 (2013); David G. Owen, Design Defects, 73 Mo. L. Rev. 291, 293 (2008).

${ }^{419}$ See RestATEMENT (THIRD) OF TORTS: PROD. LIAB. § 2 (AM. LAW INST.1998).

${ }^{420}$ Owen, Manufacturing Defects, supra note 414, 852.

${ }^{421}$ RESTATEMENT (THIRD) OF TORTS: PROD. LIAB. § 2(a) (AM. LAW InST.1998).
} 
A design defect is related to the product's design concept, which predetermines the extent to which the use of the product will result in injury to the user. ${ }^{422}$ Courts have used mainly two tests to determine the existence of a design defect: (a) the consumer expectations test, i.e. whether the product design meets the safety expectations of the users; (b) the risk-utility test, i.e. whether the safety benefits of an alternative safer design outweigh the resulting costs. ${ }^{423}$ However, the latter has become the standard test for examining potential design defects, ${ }^{424}$ and has been used also in the Restatement (Third) on Product Liability, according to which there is a defect in design, when the foreseeable risks of harm posed by the product could have been reduced or avoided by the adoption of a reasonable alternative design by the seller or other distributor, or a predecessor in the commercial chain of distribution, and the omission of the alternative design renders the product not reasonably safe. ${ }^{425}$

A product is defective because of inadequate instructions or warnings, when the foreseeable risks of harm posed by the product could have been reduced or avoided by the provision of reasonable instructions or warnings by the seller or other distributor, or a predecessor in the commercial chain of distribution, and the omission of the instructions or warnings renders the product not reasonably safe. ${ }^{426}$

According to the doctrine of crashworthiness, the foreseeable use of automobiles includes being involved in accidents; hence, a reasonably safe vehicle should not aggravate the injuries sustained by the driver or the passengers as a result of the primary impact. ${ }^{427}$ In other words, a vehicle should be reasonably safe to occupy even in collision impacts. Such defect in the vehicle's design or construction makes the manufacturer liable for that portion of the damage or injury caused by the defect over and above the damage or injury that would probably have resulted from the impact or collision absent the defect. ${ }^{428}$ The crashworthiness doctrine has been applied by many courts involving all types of defects. ${ }^{429}$ It has also been included in the Restatement (Third) on Product Liability as "increased harm due to product defect". 430

In the context of AV, the NTSB reports on the Tesla and Uber accidents provide interesting clues as to what could be considered a design defect. In the Tesla accident, the NTSB recommended to manufacturers of L.2 automation vehicles to incorporate system safeguards that limit the use of automated control systems to those conditions for which they were designed, and to develop applications that effectively sense the driver's level of engagement and alert the driver when engagement is lacking. ${ }^{431}$ In the Uber accident, the NTSB recommended that, for test vehicles, ADS functional limitations that create safety risks should

\footnotetext{
422 Owen, Design Defects, supra note 418, 291.

${ }^{423} I d$., 299.

${ }^{424} I d ., 307,309$.

${ }^{425}$ Restatement (ThiRd) OF TORTS: PROD. Liab. § 2(b) (AM. LAW Inst.1998).

${ }^{426}$ RESTATEMENT (THIRD) OF TORTS: PROD. LiAB. § 2(c) (AM. LAW INST. 1998).

${ }^{427}$ Larsen v General Motors Corporation, 391 F.2d 495, paras 33-34 (8th Cir. 1968).

${ }^{428} I d$, paras 35-36.

${ }^{429}$ R. Ben Hogan, The Crashworthiness Doctrine, 18 Am. J. Trial Advoc. 37, 42 (1994).

${ }^{430}$ See Restatement (ThIRD) OF TORTS: Prod. LiAB. § 16 (AM. LAW InST. 1998).

${ }^{431}$ NTSB, supra note 409 , at 43-44.
} 
be mitigated through a safety management system that, at a minimum, includes safety policy, safety risk management, safety assurance, and safety promotion. ${ }^{432}$

Concerning potentially inadequate instructions or warnings, it is noteworthy that two consumer advocacy groups, the Centre for Auto Safety ${ }^{433}$ and the Consumer Watchdog ${ }^{434}$ have sent a letter to the Federal Trade Commission and the California Department of Motor Vehicles alleging that Tesla's advertising, statements and marketing materials are misleading, as they give the impression that its Autopilot system is far more capable than it currently is.

\subsubsection{Recoverable damages}

There are four types of damages recoverable in product liability cases: (a) compensatory damages, (b) pain and suffering endured as a result of the injury, (c) loss of consortium to compensate for the effect the injury had on a marital relationship and (d) punitive damages, if the defendants' conduct was egregious. ${ }^{435}$

The US Supreme Court has established a triple test to determine whether an award of punitive damages violates the constitutional due process requirements: (1) the reprehensibility of the defendant's conduct, (2) the ratio of punitive damages to actual harm, and (3) the size of the award vis-à-vis the statutory sanctions for comparable misconduct. ${ }^{436}$ As to the first criterion, the US Supreme Court has ruled that a court must consider whether: the harm was physical rather than economic; the tortious conduct evinced an indifference to or a reckless disregard of the health or safety of others; the conduct involved repeated actions or was an isolated incident; and the harm resulted from intentional malice, trickery, or deceit, or mere accident. ${ }^{437}$ Regarding the ratio of punitive damages to actual harm, the Court has been reluctant to identify concrete constitutional limits; however, it has stated that, in practice, few awards exceeding a single-digit ratio between punitive and compensatory damages will satisfy due process, ${ }^{438}$ while awards exceeding a 4:1 ratio will be very close to unconstitutionality. ${ }^{439}$ Besides, many jurisdictions restrict the amount of awardable punitive damages. ${ }^{440}$

\footnotetext{
${ }^{432}$ NTSB, supra note 410 , at 5 .

433 The letter, dated May 23, 2018, is available at https://www.consumerwatchdog.org/sites/default/files/201907/CWD\%20and\%20CAS\%20Tesla\%20Autopilot\%20Letter\%20to\%20DMV\%202019.pdf (Nov. 27, 2019).

434 The letter, dated July 25, 2019, is available at https://www.consumerwatchdog.org/sites/default/files/201907/CWD\%20and\%20CAS\%20Tesla\%20Autopilot\%20Letter\%20to\%20DMV\%202019.pdf (Nov. 27, 2019)

${ }^{435}$ See Fundamentals of Product Liability Law, LEXIS HuB https://www.lexisnexis.com/legalnewsroom/lexishub/b/commentary/posts/fundamentals-of-product-liability-law (Nov. 18, 2019)

${ }^{436}$ BMW of North America vs. Gore, 517 U.S. 559, 575 (1996).

${ }^{437}$ Id., 576-577.

${ }^{438}$ State Farm Mut. Automobile Ins. Co. v. Campbell, 538 U.S. 408, 425 (2003).

${ }^{439}$ BMW of North America vs. Gore, 517 U.S. 559, 581 (1996); Pac. Mut. Life Ins. Co. v. Haslip, 499 U.S. 1, 23-24 (1991).

${ }^{440}$ For an overview of the state legislation see W. McDonald Plosser, Sky's The Limit? A 50-State Survey Of Damages Caps And The Collateral Source Rule, Dec. 11, 2018, MONDAQ.COM http://www.mondaq.com/unitedstates/x/762574/Insurance/Skys+The+Limit+A+50State+Survey+Of+Damages+ Caps+And+The+Collateral+Source+Rule (Nov. 27, 2019).
} 


\subsubsection{Liable parties}

Liable could be the manufacturer of the end product, the component manufacturer, persons in the supply chain of the product (sellers, resellers, wholesalers, distributors) and/or anyone who repaired or modified the product. ${ }^{441}$

\subsubsection{Road traffic liability}

Road traffic liability is based on negligence whose exact elements may differ from state to state. $^{442}$

The use of motor vehicles is regulated in many states by statute and some courts find that violation of such statutes creates a presumption of negligence, negligence per se or a reversal of the burden of proof. ${ }^{443}$ The driver is under a duty to exercise due care, including keeping the vehicle under reasonable control at all times, maintain a proper lookout for any risks, and avoid collision or contact with other vehicles, pedestrians and persons properly using the highway. ${ }^{444}$ Maintaining the vehicle in proper and safe condition, including the proper functioning of its safety equipment is also an important factor in determining negligence, often influenced by statutory requirements. ${ }^{445}$ A duty of care is owed also to passengers or guests of the vehicle, although some state guest statutes still require that the driver must have been gross negligent or reckless to incur liability. ${ }^{446}$

In the context of automating driving, the NTSB report on the Tesla accident in Florida concluded that, among others, the driver was inattentive and over-relied on vehicle automation. ${ }^{447}$ In the Uber accident in Arizona, the NTSB report concluded that the driver failed to monitor the driving environment and the operation of the ADS. ${ }^{448}$ Thus, in liability terms, in both cases the human drivers of the vehicle operated in automation mode seem to have violated their duty to a proper lookout.

\subsection{Motor vehicle insurance}

Motor vehicles insurance is regulated at state level and is not uniform across states. State legislation provides for minimum insurance limits for vehicle owners regarding death and

\footnotetext{
${ }^{441}$ Fundamentals of Product Liability Law, supra note 435.

${ }^{442}$ See an overview of each state's requirements for establishing negligence at https://statelaws.findlaw.com/accident-and-injury-laws/negligence-laws.html (Nov. 26, 2019).

${ }_{443}$ 2A American Law of Torts $\S 9: 36$, Westlaw (database updated March 2019) at*3.

${ }^{444} I d$., at $* 3$ and $* 9$.

${ }^{445} I d$., at $* 6$.

${ }^{446} I d$., at *4.

447 Supra note 409.

448 Supra note 410.
} 
bodily injury, and property damage insurance for injuries and damage caused to third parties. ${ }^{449}$ In some states additional coverage is required, which may include personal injury protection, uninsured motorist coverage and underinsured motorist coverage. ${ }^{450}$

Personal injury protection or no-fault insurance covers the vehicle driver as well as persons both within the vehicle (passengers) and outside of it (e.g. pedestrians, cyclists) regardless of who is at fault or negligent. ${ }^{451}$ Uninsured motorist coverage covers cases of accidents caused by an uninsured vehicle or a hit-and-run motorist. ${ }^{452}$ Underinsured coverage applies to accidents in which insurance policy limits of the at-fault vehicle are lower than the damage actually suffered. ${ }^{453}$

Regarding AV, traditional car-insurance coverage is not expected to be significantly affected in low automation levels (up to L.3), since there will be a driver in charge of the vehicle operation. ${ }^{454}$ However, in high automation levels (L.4-5) liability is expected to shift to the manufacturer with the corresponding changes in insurance coverage. ${ }^{455}$

In any case, some states have already established minimum insurance coverage for AV and more are expected to follow. ${ }^{456}$

\subsection{The role of NHTSA}

\footnotetext{
${ }^{449}$ See on the insurance requirements of each state Automobile Financial Responsibility Laws By State, INSURANCE INFORMATION INSTITUTE https://www.iii.org/automobile-financial-responsibility-laws-by-state, July 2018 (last visited Nov. 25, 2019); Digest of Motor Laws, Liability Laws, AMERICAN AUTOMOTIVE ASSOCIATION https://drivinglaws.aaa.com/tag/liability-laws/ (Nov. 25, 2019); Minimum liability car insurance requirements by state, Apr. 11, 2019, CARINSURANCE https:/www.carinsurance.com/Articles/minimum-liability-carinsurance-requirements-by-state.aspx (Nov. 25, 2019).

${ }^{450}$ Minimum liability car insurance requirements by state, supra note 449; See e.g. New York Minimum Auto Insurance Requirements Coverage, NY DEPARTMENT OF FINANCIAL SERVICES https://www.dfs.ny.gov/consumers/auto insurance/minimum auto insurance requirements (Nov. 25, 2019). ${ }^{451}$ Minimum Auto Insurance Requirements Coverage (supra note 450);Personal injury protection, Nov. 21, 2019, CARINSURANCE https://www.carinsurance.com/coverage-definition/personal-injuryprotection.aspx\#mandatory (Nov. 25, 2019).

${ }^{452}$ Minimum Auto Insurance Requirements Coverage (supra note 450); Uninsured Motorist Coverage: What you need to know, Jan. 22, 2019, CARINSURANCE https://www.carinsurance.com/uninsured-motoristcoverage.aspx (Nov. 25, 2019).

${ }^{453}$ Julia Cagan (rev.), Underinsured Motorist Coverage, updated Aug. 14, 2018, INVESTOPEDIA https://www.investopedia.com/terms/u/underinsured-motorist-coverage.asp (Nov. 25, 2019).

${ }^{454}$ Lorelie Masters et al., Rethinking insurance coverage for autonomous vehicles, 15 The SciTech Lawyer 20, 21 (2019) https://www.huntonak.com/images/content/5/9/v2/59064/Masters.pdf (Nov. 25, 2019).

${ }^{455} \mathrm{Id}$.

${ }^{456}$ See details in Autonomous Vehicles |Self-Driving Vehicles Enacted Legislation, Oct. 9, 2019, NATIONAL CONFERENCE OF STATE LEGISLATURES http://www.ncsl.org/research/transportation/autonomous-vehicles-selfdriving-vehicles-enacted-legislation.aspx (Nov. 29, 2019); Autonomous Vehicles State Bill Tracking Database, June 11, 2019, NATIONAL CONFERENCE OF STATE LEGISLATURES

http://www.ncsl.org/research/transportation/autonomous-vehicles-legislative-database.aspx (Nov. 29, 2019). E.g. Alabama imposes minimum liability insurance limits of 2,000,000 \$ - Act No. 2019-496, enacted Oct. 6, 2019; New York allows testing of AV, provided that the vehicle has a minimum, financial security in the amount of five million dollars - Act No 55, Part FF, enacted Apr. 20, 2017.
} 
The NHTSA is responsible for issuing technical safety standards and ensuring conformity therewith. ${ }^{457}$

Compliance with the Federal safety standard does not automatically exempt any person from liability at common law, including tort liability for harm caused by negligent conduct, except where preemption may apply. ${ }^{458}$ Nevertheless, failure to comply could trigger the manufacturer's liability, especially regarding mandatory safety features, ${ }^{459}$ and may even bring about the award of punitive damages. ${ }^{460}$ As to preemption, the US Supreme Court has ruled that the federal standard would supersede, if the effect of a State law tort claim would be to impose a performance standard on a motor vehicle or equipment manufacturer that is inconsistent with the federal standard. ${ }^{461}$

\subsection{Proposals for reform}

Many doctrinal writings have criticized the current liability system as inadequate and inappropriate for AV. The current product liability system is seen as inadequate because technological features of AV may be unable or highly impractical to fit into existing product liability concepts. ${ }^{462}$ Moreover, the current strict liability system is regarded as inappropriate, because increased automation and shift of liability to manufacturers are predicted to place too heavy a burden on manufacturers, hamper innovation and significantly delay the introduction of new technologies that have the potential to dramatically increase safety. ${ }^{463}$ Besides, varying state laws on liability and insurance are unhelpful for manufacturers, who are subject to different regimes and potentially conflicting judgments, increasing considerably their cost. ${ }^{464}$

As a result, there have been numerous proposals for reform, some of which we outline indicatively below.

\footnotetext{
45749 U.S.C. $\S \S 30111-30112$.

45849 U.S.C. $\$ 30103(\mathrm{e})$.

459 See Restatement (ThIRD) OF TORTs: Prod. Liab. $\$ 4 \mathrm{cmt}$ d (AM. LAW Inst. 1998).

${ }^{460}$ DEREK SWANSON \& LIN WEI, UNITED STATES AUTOMOTIVE PRODUCTS LIABILITY LAW (2nd ed. 2011), at 4 and 34, https://www.mcguirewoods.com/news-resources/publications/us-automotive-products-liability.pdf (Nov. 27, 2019).

${ }^{461}$ Geier v. American Honda Motor Co., 529 U.S. 861 (2000)

462 E.g. Kenneth S. Abraham and Robert L. Rabin, Automated Vehicles and Manufacturer Responsibility for Accidents: A New Legal Regime for a New Era, 105 VA. L. REV. 127, 142-143 (2019), who suggest that, once the use of L. 4 and L. 5 vehicles becomes widespread, litigation over the availability of reasonable alternative designs would involve challenging and technical comparisons of design risk, utility and feasibility, and would be too complex and constly; David Vladleck, Machines without principals: Liability rules and Artificial Intelligence, 89 Wash L R 117, 142 (2014), who points out to scenaria, in which autonomous vehicle behavior would make it unreasonable to infer that the accident was due to a design or manufacturing defect

${ }^{463}$ See e.g. Cyle Colonna, Autonomous cars and tort liability, 4 Case W. Res. J.L. Tech. \& Internet 81, 114-117 (2012);

${ }^{464}$ See e.g. Matthew Blunt, Highway to a Headache: Is Tort-Based Automotive Insurance on a Collision Course with Autonomous Vehicles, 53 Willamette L. Rev. 107, 131 (2017).
} 
One proposal favors the development and application of a "reasonable algorithm" standard applicable to non-human decision makers, such as AV, similar to the "reasonable person" or "reasonable professional" standard that applies to human tortfeasors. ${ }^{465}$

It has also been submitted that liability of AV owners should be modeled to liability of canine owners, because both dogs and AV may act independently from their human owners and inflict damage. ${ }^{466}$

In addition, a strict-liability system has been proposed for damage and injury caused by AV not attributable to a design or manufacturer defect, which could impose a court-compelled insurance regime. ${ }^{467}$ Such system could be financed by either the end and component manufacturers in some sort of enterprise liability, or by the AV themselves after being vested with legal personality. ${ }^{468}$

The proposal to establish a federal non-fault insurance scheme, funded by the contributions of vehicle drivers has also been put forward. ${ }^{469}$ Such scheme would practically eliminate all claims based on manufacturing and design defects; however, it should maintain claims based on crashworthiness, to incentivize manufacturers to build safer vehicles. ${ }^{470}$

Another insurance-based proposal is the creation of a federal fund at the example of nuclear energy insurance. ${ }^{471}$ Such fund would be based on two-tier liability: in the first tier, there will be limited liability; in the second tier, the indemnification costs would be covered through annual contributions of each manufacturer to the fund, by analogy to its production volume, predicted revenue and predicted amount of risk. ${ }^{472}$

Other authors suggest the creation of a special Manufacture Enterprise Liability regime (MER) for accidents caused by L. 4 and L.5 vehicles. This would be a manufacturer-financed, strictresponsibility compensation system for bodily injury, administered by a fund created through assessments levied on HAV manufacturers. ${ }^{473}$

According to another proposal, the appropriate solution would be to coordinate state tort law with federal safety regulations. Federal regulations could prescribe to manufacturers to (i) subject the vehicles to adequate pre-marketing testing and post-sale updates, and (ii) warn users about inherent risks that could lead to a crash. State tort law could then enforce such regulatory duties. $^{474}$

\footnotetext{
${ }^{465}$ Karni Chagal-Feferkorn, The Reasonable Algorithm, U. Ill. J.L. Tech. \& Pol'y 111(2018).

${ }^{466}$ Sophia H. Duffy and Jamie Patrick Hopkins, Sit, stay drive: The future of autonomous car liability, 16 SMU

Sci \& Tech. L. Rev. 453, 467-473 (2013).

467 Vladleck, supra note 462, 146 (2014).

${ }^{468}$ Id., 149-150.

${ }^{469}$ Blunt, supra note 464, 131-132.

${ }^{470} \mathrm{Id}$.

${ }^{471}$ Colonna, supra note 463, 118-119.

${ }^{472}$ Id., 124-130.

473 Abraham and Rabin, supra note 462, 145-171.

${ }^{474}$ Mark A. Geistfeld, A Roadmap for Autonomous Vehicles: State Tort Liability, Automobile Insurance, and Federal Safety Regulation, 105 Calif. L. Rev. 1611, 1674-1691 (2017).
} 
There seems to be wide support for a uniform system of liability and/or insurance across the US, as it would create legal certainty for manufacturers and insurers and facilitate deployment of new technologies. ${ }^{475}$ As external observers, we recognize that uniform rules would be very helpful. However, the lack of such rules regarding conventional vehicles does not seem to have created adverse conditions. AV incorporate advanced technology, but they remain an advanced variant of existing transportation modes. Interstate commerce and transportation has been going on relatively smoothly for many decades despite the legal fragmentation. Such fragmentation may create difficulties to the industry, which, however, do not appear insurmountable - if they were, there would have been market pressure strong enough to instigate federal legislative action. One could object to such thoughts, claiming that accidents involving conventional vehicles are due overwhelmingly to driver error, whereas AV are expected to shift liability to the manufacturer. Still, manufacturer liability has not brought about uniform liability rules even in other domains, in which it is more likely to occur.

It should also be considered that the gradual introduction of automated driving systems is expected, which means that public roads will be shared among conventional vehicles and automated vehicles of various automation degrees. ${ }^{476}$ Such mixture of conventional and automated vehicles may vary from state to state, wit different states experiencing different levels of mixed traffic. Besides, states have been traditionally regulating liability and insurance issues and are not likely to welcome any transfer of responsibilities to the federal government. Thus, uniform liability and insurance rules on AV may be impractical, and even politically intolerable from their perspective.

In our view, the US experience shows the importance of uniform technical standards, which can influence liability and insurance rules in a variety of ways. The expected user and manufacturer behavior often refers, directly or indirectly, to such standards - e.g. for manufacturers a violation of safety standards could create a presumption or even establish a breach of duty of care, or indicate a defective safety design, whereas insurance coverage may be unavailable if the accident was due to violation of such standards. Therefore, common safety standards might prove more useful than uniform liability and insurance rules.

\subsection{Comparison of US and European legal systems}

Both the US and EU legal rules on AV present elements of fragmentation and coherence at different levels.

\footnotetext{
475 Beside the above-mentioned literature, supra notes 467-473, see among others Eric Cheng, OBAMACARS: Applying an Insurance Mandate to Manufacturers of Fully Autonomous Vehicles, 87 Geo. Wash. L. Rev. 973, 993-995 (2019), who proposes mandatory federal product liability insurance; K.C. Webb, Products Liability and Autonomous Vehicles: Who's Driving Whom, 23 Rich. J.L. \& Tech. 1, 48-49 (2017), who favors a federal limitation of liability of AV manufacturers; Jessica Brodsky, Autonomous vehicle regulation: How an uncertain legal landscape may hit the brakes on self driving cars, 31 BERKL. TECH. L.J 851, 877 (2016), who seems to suggests the creation of a kind of federal tort law system applicable to AV; Carrie Schroll, Splitting the bill: Creating a national car insurance fund to pay for accidents in autonomous vehicles, 109 Nw. U. L. Rev. 803, 822-825 (2015), who proposes the creation of a federally-run national car insurance fund.

${ }^{476}$ Abraham and Rabin, supra note 462, 131-132.
} 
In the US there is a federal policy on AV, despite leaving many implementation aspects to the states. In the EU there is no clear and specific policy on AV regulation: AV are considered a special aspect of more generic AI issues. This has given the opportunity to individual European States to establish their own AV policy.

Liability and insurance issues regarding AV are determined at state level in the US. At the same time, the federal government has competency only for safety standards, which may influence the application of state rules on liability and insurance. In the EU, there are uniform rules on product safety, strict product liability and motor-vehicle insurance, while each State lays down its own rules on negligence product liability and road traffic liability.

Regarding product liability rules, they can be strict or negligence-based both in the US and in the EU. In the US, strict product liability is mainly determined according to the risk-utility test. In the EU the PLD has focused on the consumer-expectations test, although national courts sometimes consider also risk-utility aspects. Negligence product liability is applied without major differences on both sides of the Atlantic. Moreover, both US and European courts may alleviate claimants' burden of proof through inferences. However, punitive damages are either prohibited or rarely awarded in Europe.

Contrary to US legal practice, road traffic liability in European states can be unlimited and negligence based, or strict and limited, while non-fault insurance is not used. Nevertheless, both legal systems provide for uninsured vehicle insurance.

Noteworthy is also that in both legal systems the limited attempts to regulate liability and insurance of AV have focused on road traffic liability, not on product liability. Regulators on both sides of the Atlantic seem to be opting for the traditional dispute-settlement mechanisms of road traffic - at least until the industry proceeds with high-level automated vehicles. So far, regulators are leaving innovation to the industry - they are not interested in innovating themselves.

Last but not least, the US does not seem to worry too much about the international-law aspects of road traffic. Being a party only to the 1949 Geneva Convention and not to the 1968 Vienna Convention, while only the latter allows driving with hands off the wheel, means that US national legislation may not be living up to US duties under international law.

As a result, although the EU is no federal State, the legal landscape in the EU is in some aspects more uniform compared to the US. However, under both systems there seems to be a limited appetite for new liability and insurance rules, before high-level automation technologies have been developed enough to be massively deployed.

\section{Considerations de lege ferenda}

\subsection{Need for clarity}


Perhaps the most important issue in liability for AV is clarity both with respect to third-party compensation and redress actions.

First of all, we need to clarify the primary liable person. It would be very useful to channel liability to a single person or entity, i.e. the driver or the manufacturer, who could then take redress against other potentially liable parties. We consider it more appropriate to establish strict liability of the driver, whose insurer would settle the claims of third parties. There will be vehicles of various levels of automation on the roads for many years to come, while road traffic insurers have already extensive know-how in such claims. Therefore, it would be much simpler for third parties to turn against these insurers than having to determine the appropriate liable person by examining whether the vehicle was being driven in automated mode and whether the human or the ADS was responsible for the accident.

Second, we need clarity of concepts. A clear definition of the 'automated vehicle' is necessary, i.e. when a vehicle should be considered to operate in automated mode. Under the PLD, especially the concepts of 'product' and 'defect' create significant problems when applied to AV. A 'product' should also include software, even if it is not incorporated in a physical medium. This would cover suppliers of defective over-the-air updates, which could cause damage to third parties. As to 'defects', violation of traffic rules should qualify as such. Learned behaviour of the AV that causes an accident could be regarded as a defect that existed when the product was put into circulation. Nevertheless, it has been correctly observed that selflearning algorithms might cause damage regardless of any defect as they rely on probabilitybased predictions, and probabilities by nature get it wrong some of the time. ${ }^{477}$

Third, we need situational clarity during the operation of the AV. ${ }^{478}$ The vehicle should indicate whether it is operating in automated mode, the health of its systems, whether it is unable to continue operating in automated mode because of a system failure or because it is outside its ODD, whether the human driver is required to intervene and what is expected to do, as well as confirmation of handing over control to the human driver.

Fourth, clarity as to the reconstruction of the accident is necessary. Event Data Recorders should be mandatory equipment in any AV and should be capable of collecting all necessary evidence in case of an accident: space-time coordinates of the vehicle, mode of operation, speed, direction, health of the system, request to the driver to intervene or activation of the automated mode, confirmation of handing over control to the human or the ADS. ${ }^{479}$ Moreover, the storage period of the EDR data should be clearly provided in the law, as well as the persons who have access to the data. Since all these provisions should conform to the applicable data protection rules, especially the General Data Protection Regulation (GDPR), ${ }^{480}$ official

\footnotetext{
${ }^{477}$ Karni A. Chagal-Feferkorn, Am I an Algorithm or a Product: When Products Liability Should Apply to Algorithmic Decision-Makers, 30 STAN. L. \& POL'Y REV. 61, 84 (2019).

${ }^{478}$ See Association of British Insurers (ABI) \& Thatcham Research, Assisted and Automated Driving, Technical Assessment, June 12, 2018, https://www.mynewsdesk.com/uk/thatcham-research/documents/thatcham-researchassisted-and-automated-driving-definitions-technical-assessment-79493 (last visited July 31, 2019) 8-13. ${ }^{479}$ Id., at 12 .

480 Parliament and Council Regulation (EU) 2016/679 2016 O.J. (L 119), 1.
} 
guidance documents regarding the relation of such provisions with personal data protection would be useful.

\subsection{AV and Ethics}

Ethics is an important factor in AV regulation and in AI in general. It is not accidental that ethics reports commissioned by official institutions have preceded new pieces of legislation in AV in Europe. ${ }^{481}$ Ethics considerations provide guidance as to what would be the desirable, or at least acceptable, content of regulation in a specific jurisdiction. As ethics concepts vary among societies, there are no universally agreed ethical principles. ${ }^{482}$ Nonetheless, it might be possible to discern some common principles in Europe.

Deployment of AV requires that they achieve a minimum level of safety, which exceeds that of human drivers. AI systems should produce safety gains, not exacerbate harm to humans. ${ }^{483}$

The decision-making process of ADS should be transparent and explicable. Full technical transparency may not be possible, at least for the time being, owing to the high complexity of some AI systems. ${ }^{484}$ Nevertheless, a certain degree of explainability of decisions of the ADS, i.e. to supply the rationale behind the decision, is considered necessary. ${ }^{485}$

In case of unavoidable accidents, no distinction is allowed based on personal features, such as gender, age, etc, neither is permitted to offset victims against one another. ${ }^{486}$ Such behavior would violate the respect of human dignity, which should be at all times observed when deploying AI. ${ }^{487}$

\subsection{Special risks of $\mathrm{AV}$ and insurability}

AV present no particularities as to their disaster potential compared with ordinary vehicles. They operate in a different mode, yet their potential for personal injuries and property damages

\footnotetext{
${ }^{481}$ See German Ethics Commission, supra note 144, House OF LORDS SCIENCE AND TECHNOLOGY SELECT COMMITTEE, AI IN THE UK: READY, WILLING AND ABLE? 2017-19 HL 100 (UK) [hereinafter HL Committee on AI]; EUROPEAN COMMISSION HIGH LEVEL EXPERT GROUP ON ARTIFICIAL INTELLIGENCE, ETHICS GUIDELINES FOR INDEPENDENT AI, Apr. 8, 2019, https://ec.europa.eu/newsroom/dae/document.cfm?doc id=58477 (last visited July 31, 2019) [hereinafter EU Commission Ethics Guidelines].

${ }^{482}$ See the results of the Moral Machine experiment, which gathered 40 million decisions in ten languages from millions of people in 233 countries and territories in Edmond Awad et al., The Moral Machine experiment, 563 Nature 59 (2018). See also John Thornhill, Formulating values for AI is hard when humans do not agree (July 22, 2019), FINANCIAL TIMES, https:/www.ft.com/content/6c8854de-ac59-11e9-8030530adfa879c2?desktop=true (last visited July 23, 2019).

${ }^{483}$ EU Commission Ethics Guidelines, supra note 481, at 12; German Ethics Commission, supra note 144, at 6 and 9, principle no 2 and 18 respectively.

${ }^{484}$ EU Commission Ethics Guidelines, supra note 481, at 21.

${ }^{485}$ EU Commission Ethics Guidelines, supra note 481, at 13 and 18; European Parliament resolution of 16 February 2017 with recommendations to the Commission on Civil Law Rules on Robotics (2015/2103(INL), 239, 244, principle no 12, OJ (C 252), July 18, 2018; HL Committee on AI, supra note 481, paras. 99 and 105. ${ }^{486}$ German Ethics Commission, supra note 144, at 7, principle no 9.

${ }^{487}$ EU Commission Ethics Guidelines, supra note 481, at 10.
} 
do not differ from those of ordinary cars. An AV, even in case of unlawful interference with its operation, could cause no greater damage than an ordinary car. Thus, from an insurance perspective the probable maximum loss remains unchanged.

In this regard, the AV industry is different than the nuclear-energy industry as well as the shipping and aviation industries. These activities have catastrophic potential, which is hard to quantify and call for a liability cap to be rendered insurable. The nuclear accidents in Chernobyl $^{488}$ and Fukushima ${ }^{489}$, as well as the oil-spill cases of Deep Horizon ${ }^{490}$ and Exxon Valde $\mathrm{z}^{491}$ have demonstrated their immense disaster potential in terms of public health and environmental damages. Moreover, the 9/11 attacks have demonstrated the enormous insurance risks arising from the deliberate misuse of aviation. ${ }^{492}$ Nonetheless, even the most extreme cases of terrorists using cars as weapons ${ }^{493}$ are dwarfed by the above-mentioned cases.

What is special about AV is the shift of liability from the driver/owner to the manufacturer, which increases the manufacturer's exposure to liability. However, such risk is temporary and inherent in all new technologies, until they mature. An associated parameter relates to the potential disruption of the traditional insurance market, in the sense that manufacturers may opt to establish their own insurance companies, to cover their risks. Nevertheless, as long as the risk remains insurable, the potential re-organization of the insurance market should be of no concern to the legislator of a market economy.

Thus, the disaster potential of AV does not justify an amendment of the current liability status through a special liability cap.

\subsection{AV, strict liability and media}

States have a variety of ways to regulate liability resulting from road accidents, which makes the creation of a unified regime for liability resulting from the use of AV difficult, if not impossible. However, we have reached a point in the development of AV where a policy decision on the liability framework governing their operations shall be made. This issue becomes even more topical for jurisdictions that use a fault-based liability system for injuries caused by conventional vehicles.

\footnotetext{
${ }^{488}$ Chernobyl Accident 1986, WORLD NUCLEAR ASSOCIATION https://www.world-nuclear.org/informationlibrary/safety-and-security/safety-of-plants/chernobyl-accident.aspx (last visited July 22, 2019).

${ }^{489}$ Fukushima Daiichi Accident, WORLD NUCLEAR ASSOCIATION https://www.world-nuclear.org/informationlibrary/safety-and-security/safety-of-plants/fukushima-accident.aspx (last visited July 22, 2019).

${ }^{490}$ Deepwater Horizon - BP Gulf of Mexico Oil Spill, ENVIROMENTAL PROTECTION AGENCY

https://www.epa.gov/enforcement/deepwater-horizon-bp-gulf-mexico-oil-spill (last visited July 22, 2019).

${ }^{491}$ Exxon Valdez Spill Profile, ENVIROMENTAL PROTECTION AGENCY https://www.epa.gov/emergencyresponse/exxon-valdez-spill-profile (last visited July 22, 2019).

${ }^{492}$ How much did the September 11 terrorist attack cost America?, INSTITUTE FOR THE ANALYSIS OF GLOBAL SECURITY http://www.iags.org/costof911.html (last visited July 22, 2019).

${ }^{493}$ Terrorist Attacks by Vehicle Fast Facts, CNN.COM (updated Aug. 20, 2018 18:20 GMT), https://edition.cnn.com/2017/05/03/world/terrorist-attacks-by-vehicle-fast-facts/index.html (last visited July 22, 2019).
} 
We believe that strict liability of the manufacturers shall be the framework of choice for the following two reasons. Firstly, a fault-based system would put on third parties injured by AV the additional (expensive) burden of understanding an evolving new technology and explaining what went wrong with it. Such a burden puts them in a disadvantageous position towards victims of conventional vehicles and allocates the cost of technological development on them rather than the risk creator or user of the AV. On the contrary, a system of strict liability would channel the cost of accidents to the risk creators and motivate them to improve the safety levels of AV. Judging from the level of investment in the development of $\mathrm{AV}$, we believe that the industry does not require a liability subsidy granted by third party victims.

Secondly, the allocation of the risk of accidents to third parties is a policy decision that has the potential to slow down the deployment of AV. This is so because AV accidents are a first-rate opportunity for media to construct a dramatic version of reality by simplifying technical information and amplifying liability issues. ${ }^{494}$ Creating a liability system that does not provide full protection to third parties suffering personal injuries from the malfunctions of AV will only fuel a (false) perception of AV manufacturers as greedy profiteers who cut corners on safety and liability regulation for profit. ${ }^{495}$

At the same time, strict liability will provide for a liability system that assists the public image of AV. Aviation insurers realised in the $80 \mathrm{~s}$ and $90 \mathrm{~s}$ that taking a strict approach to the settlement of (some well-publicised) claims while improving the industry's public image is an impossible task. ${ }^{496}$ The end result was for insurers to support a liability scheme that was designed to facilitate the quick settlement of disputes via a system of strict and unlimited liability. ${ }^{497}$

Currently in the EU such strict liability is already in force through the PLD. The PLD is under review, to adjust its provisions to the necessities of the AI application. Its full-harmonization character entails that EU MS may not proceed to own legislative initiatives.

\subsection{AV and benefits for society}

AV promise to make roads much safer, reduce congestion and enhance environmental protection. ${ }^{498}$ However, the use of AV is not going to revolutionize people's lives, as other technological advances did. For example, aviation reduced dramatically travel time in long distances, enabling people to travel to any place of the world within hours rather than within months, as was previously the case. Nuclear energy enabled production of great amounts of environmental friendly energy, compared to fossil fuels, at low operational cost. Even ordinary automotive vehicles changed radically people's lives, by reducing distances and contributing

\footnotetext{
${ }^{494}$ GEORGE LELOUDAS, RisK AND LiABILITY IN AIR LAW $§ \S 2.46$ (2009).

${ }^{495} I d ., \S 2.55$.

${ }^{496}$ Id., $\S \S 4.138-4.142$.

${ }^{497}$ Convention for the Unification of Certain Rules for International Carriage by Air, May 28, 1999, 2242

U.N.T.S. 309.

${ }^{498}$ See supra note 2.
} 
to the formation of modern big cities. On the contrary, AV are the next step of an already existing technology. It brings significant advantages to our way of living, yet it is not the breakthrough that advertisements often portray it to be.

Consequently, there is no justification for affording special liability protection to AV owners or manufacturers.

\subsection{Human factors}

In allocating liability between the driver and the manufacturer, it is important to take human factors into account. They are important in establishing the liability of both the driver for negligence and the manufacturer for design defects and failure to warn.

A series of studies have identified the following human factors involved in automated driving: ${ }^{499}$

The driver's behaviour changes according to the level of automation engaged. For example, highly automated driving (HAD), which automates both longitudinal (acceleration/deceleration) and lateral motion (steering), has been found to be markedly different than Adaptive Cruise Control (ACC), which automates only longitudinal motion. This is so because the driver of a highly automated car has the possibility to divert attention to secondary tasks, whereas an ACC driver still has to attend to the roadway. ${ }^{500}$

Drivers in HAD conditions respond slower to safety-critical events, especially when they are engaged in non-driving tasks, such as reading or watching a movie. ${ }^{501}$ Regarding non-critical tasks, the reaction time of the driver to take-over requests from the system was about 10 seconds, although shorter reaction times are possible. ${ }^{502}$ However, it has been shown that resuming control of the vehicle fully and effectively requires $30-40$ seconds. ${ }^{503}$ In addition, the request from the system to the driver to engage the manual mode must be both visual and audible to be effective. ${ }^{504}$

Drivers of AV may benefit from systems and mechanisms which provide assistance not only after the take-over request by the automated system, but also specifically for the time period

\footnotetext{
${ }^{499}$ See for example the results of AdaptIVe, an EU co-funded research project, which identified 27 functional human-factors recommendations ('system should do') and 80 non-functional recommendations ('system should be') Johan Kelsch et al., Deliverable D.3.3, Final functional Human Factors recommendations, May 30, 2017 , https://www.researchgate.net/publication/322682304_Final_functional_Human_Factors recommendations_Diss emination_level_PU_Version_33_Final (last visited July 31, 2019).

${ }_{500}$ Joost C.F. de Winter et al., Effects of adaptive cruise control and highly automated driving on workload and situation awareness: A review of the empirical evidence, 27 Transportation Research Part F, 196, 207(2014).

${ }^{501}$ Sijun Shen \& David M. Neyens, Assessing drivers' response during automated driver support system failures with non-driving tasks, 61 Journal of Safety Research 149, 153-154 (2017).

502 Vivien Melcher et al., Take-Over Requests for automated driving, 3 Procedia Manufacturing 2867, 2872 (2015).

${ }^{503}$ Natasha Merat et al., Transition to manual: Driver behaviour when resuming control from a highly automated vehicle, 27 Transportation Research Part F 274, 280 (2014).

${ }^{504}$ Vivien Melcher et al., supra note 502, 2873.
} 
shortly after the driver has deactivated the automation. Such assistance could have the form of emergency braking and lane departure warning, keeping a minimum distance to the lead vehicle and preventing lane changes when other vehicles are in the adjacent lanes. ${ }^{505}$

Moreover, drivers of vehicles in highly automated modes tend to demonstrate overreliance on their vehicle, ${ }^{506}$ which has been confirmed by both the Tesla and the Uber accidents, ${ }^{507}$ as well as by a recent incidence. ${ }^{508}$ At the same time protracted HAD appears to be tedious, reduce situation awareness and intensify driver drowsiness, exclusively in light traffic. ${ }^{509}$ Monitoring the roadway for potential hazards during HAD induces mental workload and stress, because the driver undertakes a passive role and must supervise the activity of imperfect automation, ${ }^{510}$ and results in gradual fall of vigilance and performance. ${ }^{511}$ Humans are not good at monitoring automated tasks for prolonged time. ${ }^{512}$ Manufacturers that require drivers to remain vigilant for extended periods create an impossible task, in which humans are bound to fail. ${ }^{513}$

In this regard, the introductory information on the use of AV that manufacturers provide to drivers is crucial. A focus on the automated driving system's competence without an appropriate elaboration of its limitations might lead to misplaced trust. ${ }^{514}$

The above-mentioned findings are not conclusive and behavioural studies underline the need for further research. ${ }^{515}$ Nevertheless, they indicate that shifting control of the vehicle and therewith liability cannot occur instantly.

\subsection{International uniform rules}

An additional factor to be considered is the possibility to have international uniform liability rules. Lack of harmonization on AV means that manufacturers have to identify legal risks on a per country basis, which creates market fragmentation and high compliance costs. ${ }^{516}$ Therefore, harmonized rules would enhance legal certainty for all parties involved and advance technological development.

\footnotetext{
505 Tobias Vogelpohl et al., Transitioning to manual driving requires additional time after automation deactivation, 55 Transportation Research Part F, 464, 480-481 (2018).

506 See Erfan Aria, Johan Olstam \& Christoph Schwietering, Investigation of Automated Vehicle Effects on Driver's Behavior and Traffic Performance, 15 Transportation Research Procedia 761, 764 (2016).

${ }^{507}$ See NTSB reports, supra notes 431 and 432.

508 See David Z. Morris, U.K. Tesla Driver Gets 18-Month Driving Ban For Trusting Autopilot Way Too Much FORTUNE (Apr. 29, 2018), http://fortune.com/2018/04/29/tesla-driver-driving-ban-autopilot/ (last visited July 31, 2019).

${ }^{509}$ Aria, Olstam \& Schwietering, supra note 506, 768.

${ }^{510}$ Eric T. Greenlee, Patricia R. DeLucia, \& David C. Newton, Driver Vigilance in Automated Vehicles: Hazard Detection Failures Are a Matter of Time, 60 Hum Factors 465, 467 (2018).

${ }^{511} I d$. at 475.

${ }^{512}$ Victoria A. Banks et al., Is partially automated driving a bad idea? Observations from an on-road study, 68 Applied Ergonomics 138, 144 (2018).

${ }^{513} I d$.

${ }^{514}$ Moritz Körber et al., Introduction matters: Manipulating trust in automation and reliance in automated driving, 66 Applied Ergonomics 18, 29 (2018).

515 See e.g. Aria, Olstam \& Schwietering, supra note 506, 769; Melcher et al., supra note 502, 2873; Merat et al., supra note 503, 281; Shen \& Meyens, supra note 501, 154.

516 Study on emerging issues, supra note $11,117$.
} 
However, this is a problem connected to automotive vehicles in general, which is only amplified by the new technology of AV. Thus far, States are not particularly interested in establishing uniform liability rules on street traffic. No attempt was made to establish such rules in the early days of automotive vehicles, contrary to what happened in aviation ${ }^{517}$ and shipping $^{518}$. As discussed above, international initiatives have harmonised technical aspects of road traffic, but liability, as such, has never been the focal point of discussions. It appears that different legal traditions and diverging policy perceptions of States have prevented a common understanding. This is exemplified not only by the differences between the liability regimes of the European States, but also by the different regimes that can be followed within a single State, as the example of the different regimes within the US illustrates. ${ }^{519}$

In addition, there is no compelling necessity to introduce international, uniform rules on thirdparty liability which are perceived by States as a way of protecting defendants rather than assisting the development of the industry. This has been clearly demonstrated in aviation, where although the number and value of potential third-party claims in case of an accident are much higher than in road traffic, the great majority of States does not favour a uniform thirdparty liability regime. ${ }^{520}$ In most cases, motor vehicles are used for travel within national borders, which does not pose any major challenges as to the applicable law. This factor should be contrasted with air travel, which despite being used par excellence in international transports and crosses routinely large portions of international airspace, it has failed to attract considerable interest regarding international uniform third-party liability rules. Besides, product-liability regimes remain fragmented at international level. International efforts to harmonize at least the rules on the national law applicable to product-liability cases have proved fruitless. ${ }^{521}$

Thus, uniform international rules on third-party liability arising from AV do not seem a realistic option.

\section{Conclusion}

\footnotetext{
${ }^{517}$ See Convention for the Unification of Certain Rules Relating to International Carriage by Air, Oct. 12, 1929, U.S.T.S. No 876, 118 L.N.T.S. 301 (Warsaw Convention).

${ }^{518}$ See International Convention for the Unification of Certain Rules of Law relating to Bills of Lading For The Carriage of Goods by Sea, Aug. 25 1924, 51 U.S.T. 233, 120 L.N.T.S. 187 (Hague Rules).

${ }^{519}$ See on the different state liability regimes in the US: Sophia H. Duffy \& Jamie P. Hopkins, Sit, Stay, Drive: The Future of Autonomous Car Liability, 16 SMU Sci. \& Tech. L. Rev. 453, 457-462 (2013).

520 See Convention on Damage Caused by Foreign Aircraft to Third Parties on the Surface, 7 Oct. 1952,310 U.N.T.S. 181 (1952 Rome Convention); Convention on Compensation for Damage Caused by Aircraft to Third Parties (General Risks Convention 2009), May 2, 2009, not yet in force; Convention on Compensation for Damage to Third Parties, Resulting from Acts of Unlawful Interference Involving Aircraft (Unlawful Interference Compensation Convention 2009), May 2, 2009, not yet in force.

${ }^{521}$ See the Convention on the Law Applicable to Products Liability, Oct. 2, 1973, 11 I.L.M. 1283, which entered into force on Oct. 1, 1977, but has only 11 ratifications up to date, having failed to attract ratifications from major industrial nations, such as the US, the UK, the Russian Federation, Germany and China - see the ratification status of the Convention at https://www.hcch.net/en/instruments/conventions/status-table/?cid=84 (last visited on July $31,2019)$.
} 
AV are a much promising technological development. In the EU such developments have different legal parameters from a liability and insurance perspective.

De lege lata, the strict liability of the manufacturer under the EU Product Liability Directive practically channels liability to the manufacturer. It has to be underscored that the fullharmonization character of the Directive prevents EU member States from laying down special product-liability rules on AV.

At the same time, national legislative initiatives establish special rules on third-party liability of the user (keeper or driver), as happened in Germany, or on insurance coverage, as happened in England. In both cases, the special rules have been shaped by national traditions, and policy perceptions and priorities. In Germany, the legislators wanted to protect the national automotive industry, so they amended the rules on third-party liability of the vehicle keeper. England has a strong tradition in insurance, so it preferred to adjust the rules on insurance coverage. In both cases, legislative initiatives have a temporary character, in order to consider technological development.

Of particular interest is the effect of current international law on road traffic. European States that have ratified only the 1949 Geneva Convention and not the 1968 Vienna Convention cannot allow driving with hands off the wheel, as the former precludes such possibility.

Compared with the US, the European landscape on AV is more coherent regarding general strict product liability and motor-vehicle insurance. However, the US has a more clear and specific policy on AV. In both cases, legislators are opting for extension of current road traffic liability and insurance rules to AV, until high-level automation driving systems are developed.

De lege ferenda there is a need to balance the need for technological development with the protection of third parties.

At present, the risks and benefits from the use of AV are not making a convincing case to depart from traditional liability rules on road traffic and defective products. There is no uninsurable disaster potential and no radical change in people's lives to justify limiting the legal right of uninvolved victims to receive compensation compared to ordinary vehicles. Until all aspects for massive market deployment of $\mathrm{AV}$, including technological developments and business models, have matured, so that identification of concrete needs is possible, we see no cause for amendments. Legal issues could be tackled through common-sense interpretation of the existing rules.

Although manufacturers ought to be incentivised to introduce new technologies on AV, special liability regimes appear unnecessary. AV are advanced with the promise of unprecedented safety. It would be self-contradictory and paradoxical to introduce special liability regimes to protect manufacturers from increased risks of such new technology. If the technology is not safe enough, then its introduction should be postponed until it has achieved the desired safety levels. In the meantime, it would be more appropriate to incentivize the industry through special measures of a different nature, such as reductions in taxation and in traffic charges. 
As to international uniform liability rules, their establishment of would be desirable but seems to be neither necessary nor politically feasible. 